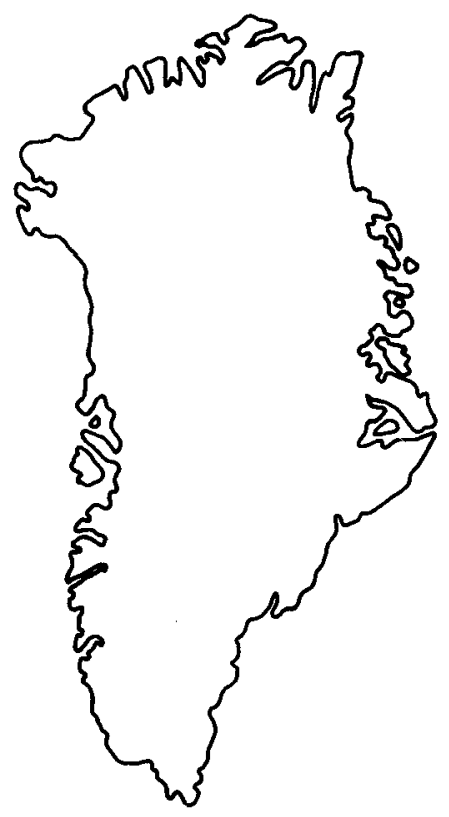

\title{
Agnostoid trilobites from the Henson Gletscher and Kap Stanton formations (Middle Cambrian), North Greenland
}

\author{
Richard A. Robison
}

\begin{abstract}
Agnostoid trilobites are abundant and diverse in 10 collections from the Henson Gletscher and Kap Stanton formations of North Greenland. Three agnostoid assemblages are identified from slope apron to deep outer shelf lithofacies, representing the Ptychagnostus gibbus, Ptychagnostus atavus, and lower Lejopyge laevigata intervalzones of Middle Cambrian age. This is the first report of fossils from the P. atavus Zone in Greenland.

At least 17 agnostoid genera are represented in the Henson Gletscher and Kap Stanton formations, of which Megagnostus and Schismagnostus are new. Diagnoses of Agnostus, Diplorrhina, Doryagnostus, Lejopyge, Peratagnostus, Peronopsis, Pseudophalacroma, and Tomagnostus are emended. From review of type material, some of which is illustrated with new photographs, Cyclopagnostus, Grandagnostus, Phoidagnostus, Quadragnostus, and Spinagnostus are considered to be unrecognisable genera.

Forty agnostoid species, some in open nomenclature, are identified from the new collections. The species Agnostus lophotus, Diplorrhina oncota, Megagnostus diclidus, Schismagnostus plicatus, and Tomagnostus bothrus are new. Abrupt early holaspid metamorphosis occurred in the cephalon of Schismagnostus plicatus and in the pygidium of Peratagnostus cicer. A lectotype is selected for Agnostus lens Grönwall, 1902, which is the type species of Cotalagnostus.
\end{abstract}

R. A. R., Department of Geology, University of Kansas, Lawrence, Kansas 660452124, U.S.A.

The geological setting, lithostratigraphy, and depositional environments of the Henson Gletscher and Kap Stanton formations are discussed in an accompanying paper by Ineson $e t$ al. (1994). These formations represent deposition in slope apron to deep outer shelf environments, and they contain rich Middle Cambrian faunas dominated by trilobite assemblages that are unusual in having Laurentian, Baltic, and mixed aspects. Systematic descriptions of the trilobites and discussions of their biostratigraphy are presented in separate papers, one on the polymeroids by Babcock (1994a), and one here on the agnostoids. Separate biostratigraphic zonations for agnostoid and polymeroid trilobites have been advocated because of major differences in their morphology, distributions, and inferred modes of life (e.g., Robison, 1976, 1984). The agnostoids were probably pelagic suspension feeders whereas most polymeroids were probably benthic deposit feeders (e.g., Robison, 1972b, 1987).
Molluscs, brachiopods, ostracods, and sponges are present in the studied collections from the Henson Gletscher and Kap Stanton formations, but they have not been studied in detail.

Analyses of selected Middle Cambrian trilobite faunas and their depositional environments suggest that differences between faunas of Laurentian and Baltic aspect are related to environmental gradients in which temperature was a major factor. This hypothesis is evaluated in another accompanying paper by Babcock (1994b), which discusses palaeogeography and trilobite biogeography.

This paper is based on diverse agnostoid trilobites (Table 1) in 10 collections from North Greenland. The fossils were collected at two localities in Nyeboe Land and at one locality in Peary Land (Fig. 1) by John S. Peel and other geologists of the Geological Survey of Greenland (GGU) during regional geological investigations. 


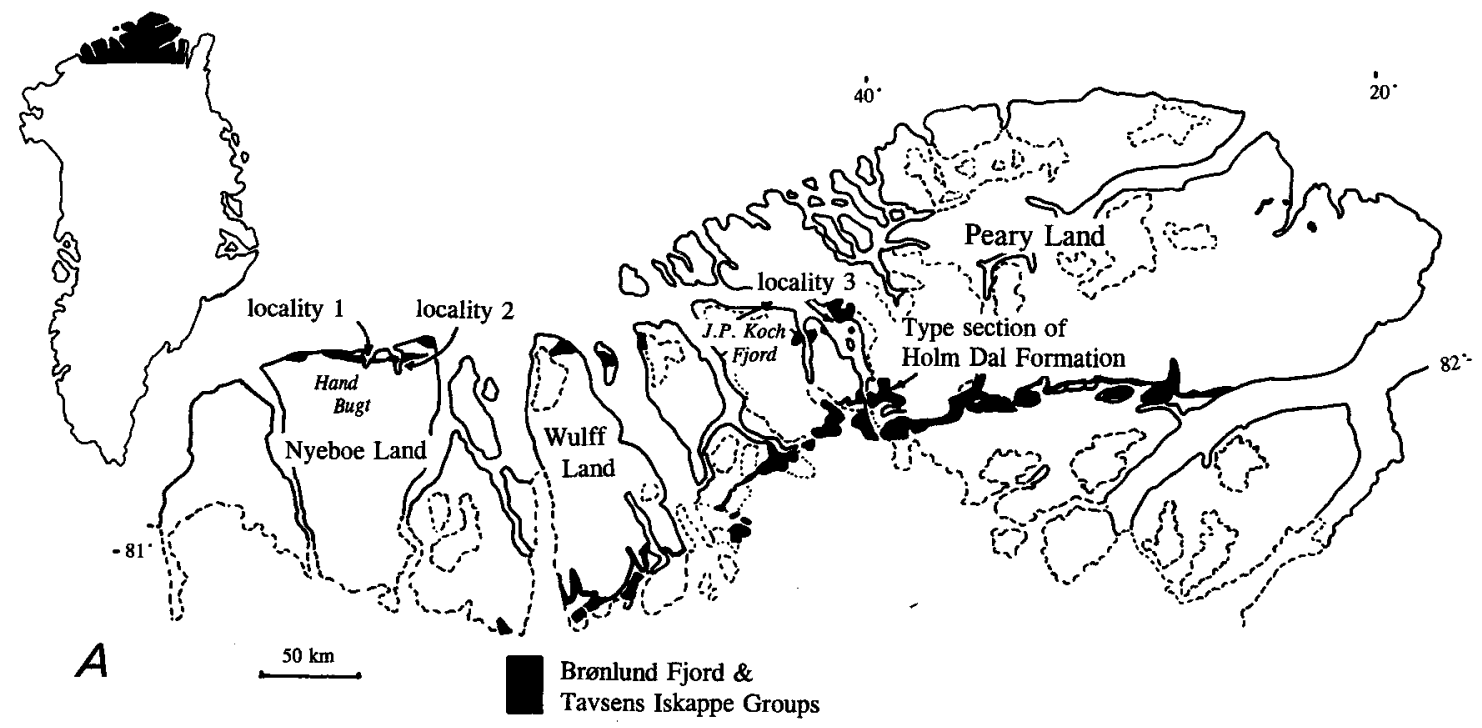

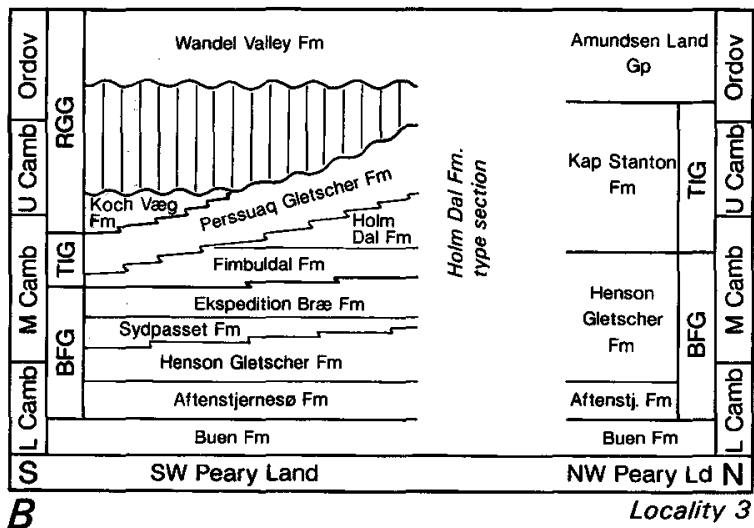

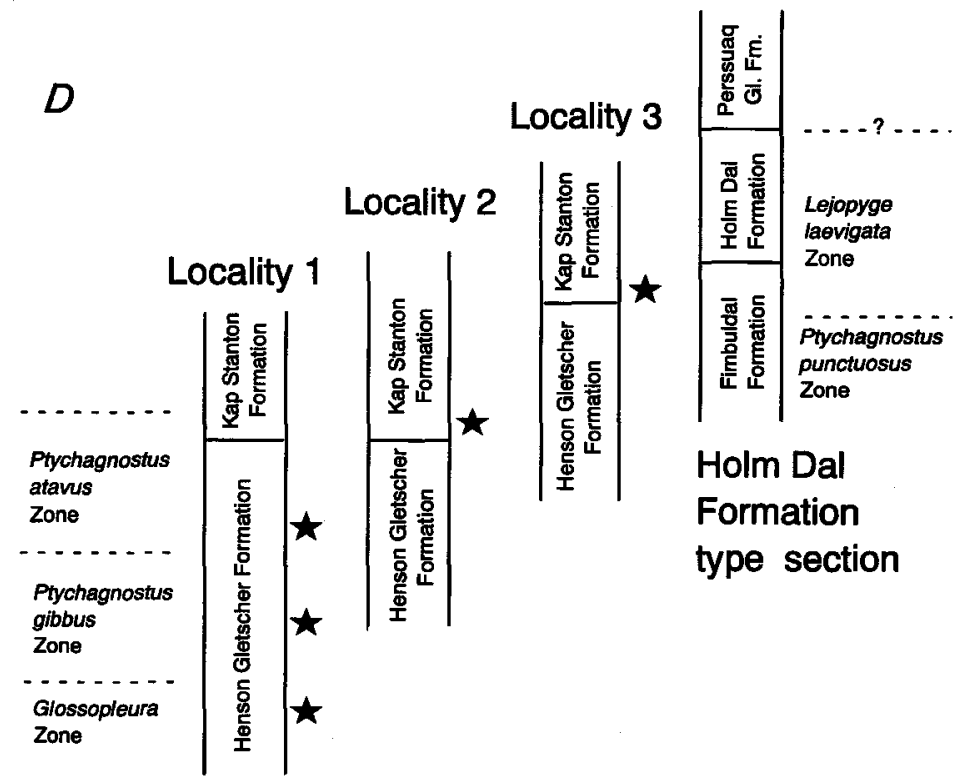

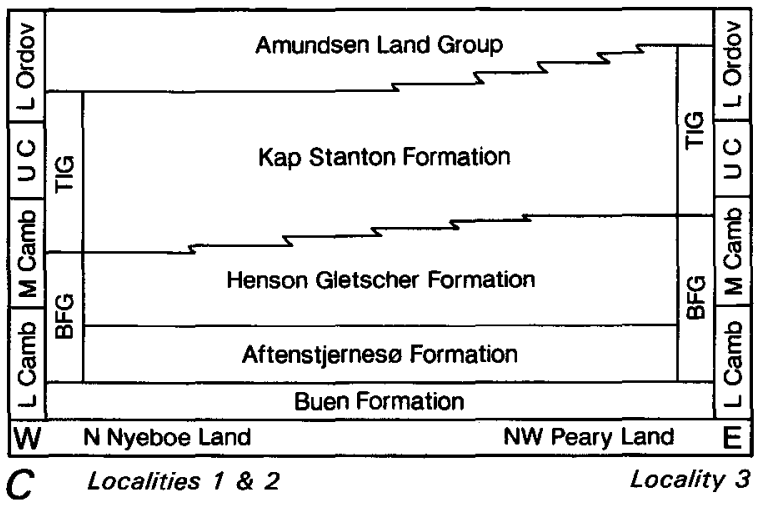

Fig. 1. Derivation of fossiliferous samples. A, map showing the distribution of the Bronlund Fjord and Tavsens Iskappe Groups in North Greenland and collection localities discussed in the text. B, C, geological crosssections through Cambrian - Lower Ordovician strata in North Greenland. BFG, Brønlund Fjord Group; TIG, Tavsens Iskappe Group; RGG, Ryder Gletscher Group (from Ineson et al., 1994). D, biostratigraphy of fossiliferous samples (stars) discussed in the text. 


\section{Biostratigraphy}

Five agnostoid interval-zones have been defined in Middle Cambrian strata (Robison, 1984, pp. 5-9). With the aid of both defining and characterising species (sensu Murphy, 1977), these zones are identifiable in many open-marine lithofacies of the world. Three of the zones, Ptychagnostus gibbus, Ptychagnostus atavus, and Lejopyge laevigata, are represented by rich and diverse agnostoid assemblages in the new GGU collections from North Greenland. Lack of fossils from the Ptychagnostus praecurrens and Ptychagnostus punctuosus zones is probably due to incomplete collecting, in part because of such problems as ground accessibility and limited field time (J. S. Peel, personal communication, 1987), rather than to gaps in the stratigraphic succession. Previous reports of trilobites from the P. punctuosus Zone in Nyeboe Land (Poulsen, 1969) and Peary Land (Robison, 1984) support this conclusion.

\section{Ptychagnostus gibbus Interval-zone}

One collection (GGU 298970) from the middle Henson Gletscher Formation of Nyeboe Land contains 12 species-group taxa (Fig. 2), including $P$. gibbus. More than half of these species are widely distributed around the world, and collectively the assemblage is most characteristic of the gibbus Zone. Other evidence supporting this zonal identification is the presence of Ptychagnostus intermedius, a common and cosmopolitan species with an observed stratigraphic range that is restricted to the gibbus Zone. Observed ranges of other species, especially that of Doryagnostus vinicensis, as revised, suggest that the collection is from the upper part of the gibbus Zone.

\section{Ptychagnostus atavus Interval-zone}

The atavus Zone is well represented by abundant specimens in five collections, all from Nyeboe Land. Of these collections, three (GGU 298969, 298974, 298975) are from the upper Henson Gletscher Formation (Fig. 2) and two (GGU 319789, 319790) are from basal beds of the Kap Stanton Formation (Fig. 3). The total zonal assemblage contains at least 24 species-group taxa, including $P$. atavus. Although fossils of this zone are widely distributed (Rowell et al., 1982), this is the first report of diagnostic species in Greenland (cf. Robison, 1984, p. 7). The presence of Ptychagnostus affinis in basal beds of the Kap Stanton Formation suggests that those beds are in the upper atavus Zone, possibly near its boundary with the Ptychagnostus punctuosus Zone.
Table 1. Classification of agnostoid trilobites identified from the Henson Gletscher and Kap Stanton formations

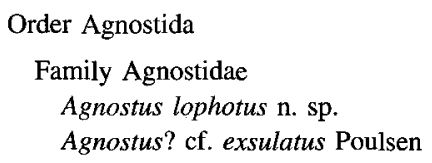

Family Clavagnostidae Clavagnostus cf. milli Jago \& Daily

Family Diplagnostidae Diplagnostus planicauda (Angelin) Iniospheniscus incanus? Öpik Linguagnostus groenwalli Kobayashi

Family Doryagnostidae Doryagnostus vinicensis (Šnajdr)

Family Metagnostidae Diplorrhina oncota $\mathrm{n}$. sp. Diplorrhina cf. sallesi (Munier-Chalmas \& Bergeron)

Family Peronopsidae Hypagnostus brevifrons (Angelin) Hypagnostus parvifrons (Linnarsson) Peronopsis bulkurensis Pokrovskaya \& Pegel Peronopsis fallax (Linnarsson) Peronopsis ferox (Tullberg) Peronopsis interstricta (White) Peronopsis cf. pusilla (Tullberg) Peronopsis scutalis (Hicks) Peronopsis sp. 1

Peronopsis sp. 2

Peronopsis sp. 3

Family Ptychagnostidae Lejopyge barrandei (Hicks) Lejopyge calva Robison Lejopyge hybridus (Brøgger) Lejopyge cf. seminula (Whitehouse) Ptychagnostus affinis (Brøgger) Ptychagnostus atavus (Tullberg) Ptychagnostus gibbus (Linnarsson) Ptychagnostus intermedius (Tullberg) Tomagnostus bothrus n. sp. Tomagnostus corrugatus (Illing) Tomagnostus fissus (Linnarsson) Tomagnostus perrugatus (Grönwall)

Family unassigned Megagnostus diclidus n. gen. \& n. sp. Megagnostus glandiformis (Angelin), $\mathrm{n}$. gen. Peratagnostus cicer (Tullberg) Phalagnostus ovalis (Illing) Schismagnostus plicatus $\mathrm{n}$. gen. \& n. sp. Toragnostus bituberculatus (Angelin)

Genus \& species undetermined 1 Genus \& species undetermined 2 
m GGU collection

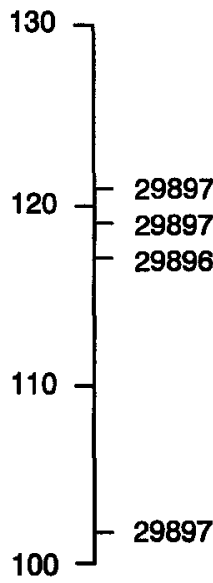
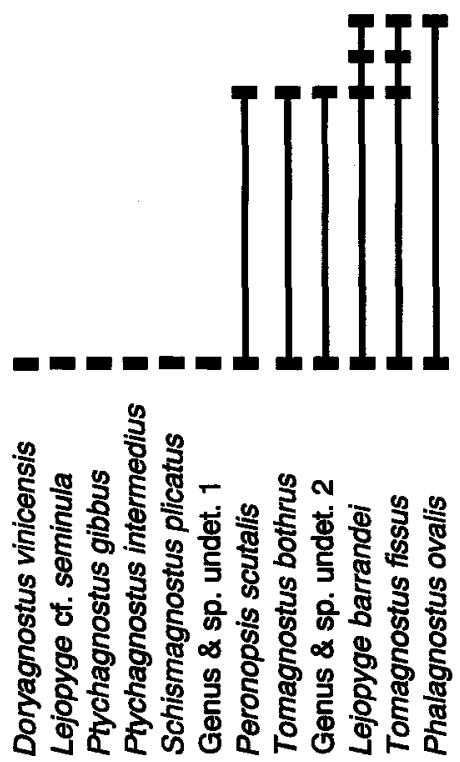

GGU collection

g
응

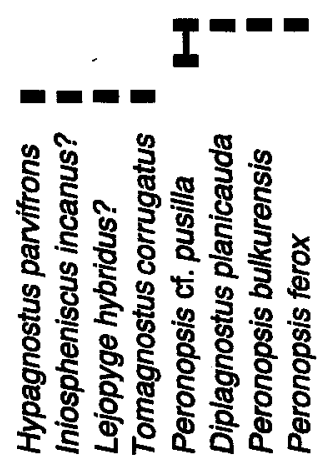

Fig. 2. Stratigraphic distribution of agnostoid species described from the upper Henson Gletscher Formation in Nyeboe Land (locality 1, Fig. 1). Scale indicates height in metres above base of formation. Six-digit numbers designate GGU collections. GGU 298970 is from the Ptychagnostus gibbus Zone. GGU 298969, 298974, and 298975 are from the Ptychagnostus atavus Zone.

\section{Lejopyge laevigata Interval-zone}

The laevigata Zone is represented by abundant specimens in four collections (GGU 301311-301313, 313115), all from basal beds of the Kap Stanton Formation in Peary Land (Fig. 4). At least 12 species-group taxa are represented, which collectively are characteristic of

\section{Agnostus? of. exsulatus Diplormina cf. sallesi Hypagnostus parvifrons Lejopyge barrandei Linguagnostus groenwalli Peronopsis fallax Peronopsis interstricta Peronopsis scutalis Peronopsis sp. 1 Phalagnostus ovalis Ptychagnostus affinis Tomagnostus perrugatus Lejopyge hybridus Peronopsis cf. pusilla Peronopsis sp. 2 \\ Ptychagnostus atavus}

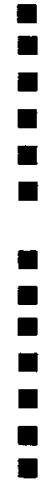

Fig. 3. Distribution of agnostoid species in GGU collections from basal beds of the Kap Stanton Formation in Nyeboe Land (locality 2, Fig. 1). Collections are not in stratigraphic sequence. Both collections are from the Ptychagnostus atavus Zone, and probably from its upper part.

\section{GGU collection}

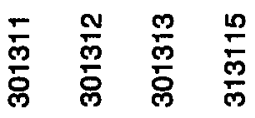

Lejopyge calva
Lejopyge hybridus?
Agnostus lophotus
Clavagnostus cf. milli
Hypagnostus brevifrons
Megagnostus diclidis
Megagnostus glandiformis
Peratagnostus cicer
Toragnostus bituberculatus
Diplagnostus planicauda
Diplorrhina oncota
Peronopsis sp. 3

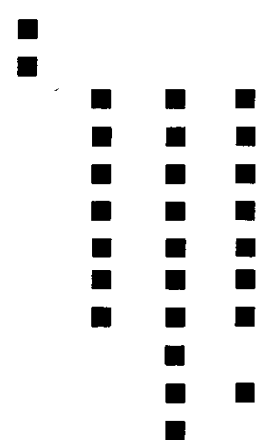

Fig. 4. Distribution of agnostoid species in GGU collections from basal beds of the Kap Stanton Formation in Peary Land (locality 3, Fig. 1). Collections are not in stratigraphic sequence. All collections are from the lower Lejopyge laevigata Zone. 
the informal lower subzone of the laevigata Zone (Robison, 1984). Although $L$. laevigata is not present in these collections, the species has been described from farther south in Peary Land (Robison, 1984, 1988), where en- closing strata of the Holm Dal Formation have been interpreted to represent deposition in an outer shelf environment (Ineson, 1988).

\section{Systematic descriptions}

\section{Terminology}

Morphological terms used here are mostly defined in the Treatise on Invertebrate Paleontology (Harrington et $a l ., 1959)$. Additional terms have been defined by Robison (1964, 1982), Öpik (1967), and Shergold et al. (1990).

A common, iterative, evolutionary trend among agnostoid trilobites was the suppression of dorsal furrows and other surface irregularities, mostly on the acrolobes. The condition resulting from advanced suppression of such features has commonly been referred to by the adjective effaced (e.g., Shergold et al. 1990, p. 11). The opposite primitive condition, with ordinary development of lobes and furrows has no commonly used term, although it has been called 'en grande tenue' by some authors (e.g., Öpik, 1967, p. 56; Shergold et al., 1990, p. 11). This latter term is not an adjective, and to simplify terminology, I here refer to the primitive agnostoid condition as furrowed. Unless otherwise stated, the furrowed condition is a character state of all taxa diagnosed here.

\section{Repositories}

All Greenland material used in this study is identified by collection or museum numbers. Repositories and their abbreviations are Geological Survey of Greenland (Grønlands Geologiske Undersøgelse), Copenhagen (GGU), and Geologisk Museum, Copenhagen (MGUH).

\section{Phylum Arthropoda}

\section{Class Trilobita}

\section{Order Agnostida Salter, 1864}

Remarks. The diagnosis of Agnostida by Robison (1984, pp. 9-10) is followed here. The author of the taxon, however, is J. W. Salter (Shergold et al., 1990, p. 4). Using recently obtained information on ventral morphology, Walossek \& Müller (1990) have critically evaluated the phyletic relationships of agnostoids and stem-lineage crustaceans. A phylogenetic analysis by Babcock (1994a) suggests that the Agnostida is monophyletic.

\section{Family Agnostidae M'Coy, 1849} Genus Agnostus Brongniart, 1822

Agnostus Brongniart, 1822, pp. 8, 38; Jaekel, 1909, p. 399; Kobayashi, 1939, pp. 159-162; Westergård, 1946, pp. 68-69, 84; Howell in Harrington et al., 1959, pp. O172-O173; Pokrovskaya in Chernysheva, 1960, p. 58; Egorova \& Pokrovskaya in Khalfin, 1960, pp. 159-160; Öpik, 1961, pp. 74-75; Palmer, 1962, p. F-12; Shergold et al., 1990, pp. 32-33 [selected references only]

Battus Dalman, 1828, pp. 136-137

Acutatagnostus Ergaliev, 1980, p. 91

Type species. Entomostracites pisiformis Wahlenberg, 1818 , p. 42 ; by monotypy. Authorship of the species name was reviewed by Rushton (1978, p. 258).

Emended diagnosis. Cephalon having preglabellar median furrow. Glabella unequally divided by transverse furrow (F3); anterior end rounded to ogival, posterior end rounded to acuminate. Basal lobes simple, may indent glabella. Genae smooth or weakly scrobiculate. Thorax unmodified. Pygidium axiolobate and simplimarginate. Axis separated from posterior border furrow; F1 and F2 moderately developed to nearly effaced; M2 with strong, oval to carinate, median tubercle. Pleural fields posteriorly confluent. Borders of cephalon and pygidium relatively narrow. Pygidial border having pair of small posterolateral spines. Border furrows increasing in relative width during ontogeny.

Remarks. Following its validation in 1822 , more than 250 species-group taxa were assigned to Agnostus, including most of the agnostoids named during the nineteenth and early twentieth centuries. With erection of many agnostoid genera during the twentieth century, most species of Agnostus were reassigned to new genera. The progressive removal of species eventually left the genus with its type species, $A$. pisiformis, and a residue of species-group taxa that mostly lack definitive generic characters. Although the species content of Agnostus has significantly changed during its taxonomic history, little attention has been given to its definition and concept. 
Following the reassignment of most of its species, a series of brief diagnoses of Agnostus were published by Kobayashi (1939, pp. 150-160), Howell (in Harrington et al., 1959, pp. O172-O173), Pokrovskaya (in Chernysheva, 1960, p. 58), Egorova \& Pokrovskaya (in Khalfin, 1960, pp. 159-160), and Palmer (1962, p. F12). Of those authors, Kobayashi was the only one to list a complement of species, and most of those were subsequently reassigned to other genera. Westergård (1946) did not give a diagnosis of Agnostus, but he did diagnose or discuss four species-group taxa under the generic name, including the new species A. neglectus. In 1967, Öpik (pp. 98-99) established the genus Innitagnostus, which he differentiated from Agnostus "and related groups (Homagnostus, Geragnostus, Micragnostus)" by the presence of "a laterally notched glabella with angulate recesses to fit the basal lobes." A new species, I. innitens, was described by Öpik as the type of Innitagnostus, and he also reassigned to that genus Agnostus inexpectans Kobayashi, 1938, A. neglectus, and Tomagnostus tchatertensis Kryskov in Borovikov \& Kryskov, 1963. Recently, Shergold et al. (1990) published the most detailed diagnoses to date of both Agnostus and Innitagnostus, but without accompanying taxonomic discussion or indication of assigned species.

After reviewing the taxonomy of Agnostus and closely related genera, I no longer support the recognition of Innitagnostus as a valid genus. Henningsmoen (1958, pl. 5 , figs 1-12) has well illustrated some of the variation observed within populations of $A$. pisiformis, the type species of Agnostus. His illustrations show that some specimens have a glabella notched to fit the basal lobes and others do not. Some specimens also have weak abaxial development of the F1 and F2 furrows, giving a 'laterally notched' aspect to the glabella, and others do not. This variation in the type species of Agnostus encompasses the only two characters cited by Öpik (1967, p. 98) to differentiate Innitagnostus from Agnostus. In my judgment, a more important character of $I$. innitens, the type species of Innitagnostus, is the near effacement of its preglabellar median furrow. This and its other characters, especially those of its axial lobe, suggest that $I$. innitens is a transitional species linking Agnostus and Micragnostus (sensu Fortey, 1980, pp. 21-22). Its observed stratigraphic occurrence also accords with this suggestion. Although the transitional characters of $I$. innitens make its generic assignment arbitrary, based on the near effacement of its preglabellar median furrow, I reassign it to Micragnostus. Consequently, Innitagnostus is considered to be a junior synonym of Micragnostus.

Among the characteristic features of Agnostus is a preglabellar median furrow, which normally is absent in late holaspid instars of Micragnostus. A vestige of the furrow, however, may be evident in younger instars of some species of Micragnostus (e.g., M. intermedius; see Robison \& Pantoja-Alor 1968, pl. 97, figs 3-5, as reassigned by Fortey, 1980, p. 21).

Agnostus, as emended, includes A. pisiformis (Wahlenberg, 1818), A pater Westergård in Holm \& Westergård, 1930, A. inexpectans Kobayashi, 1938, A. neglectus Westergård, 1946, A. exsulatus Poulsen, 1960, A. acutatus (Ergaliev, 1980), and A. Lophotus n. sp. (described below). Acutatagnostus acutatus Ergaliev (1980, pp. 91-92, pl. 11, figs 16, 17), the type species of Acutatagnostus Ergaliev, 1980, has the anterior part of the preglabellar median furrow effaced, but otherwise it conforms to the emended diagnosis of Agnostus. Because the preglabellar median furrow weakens forward in such species

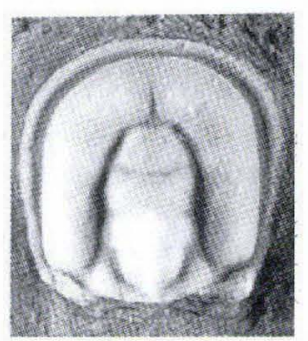

$1 \mathrm{a}$

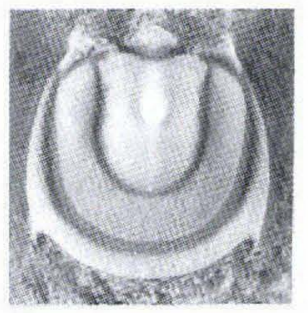

$4 \mathrm{a}$

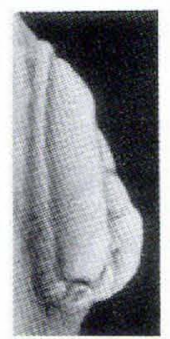

$1 b$

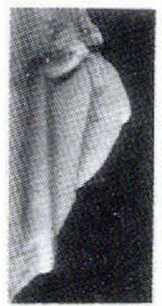

$4 b$

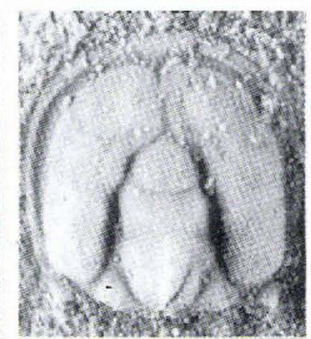

2

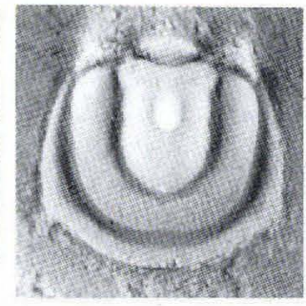

5

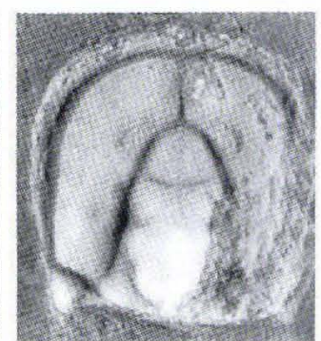

3

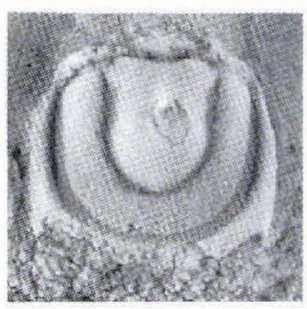

6
Fig. 5. Agnostus lophotus n. sp. All specimens from GGU 301313, unless otherwise stated, and all $\times 12$. $1 \mathrm{a}, \mathrm{b}$, cephalon in dorsal and lateral views, MGUH 21.335. 2, latex cast of cephalon, MGUH 21.336 from GGU 313115. 3, cephalon, MGUH 21.337 from GGU 313115. 4a, b, holotype pygidium in dorsal and lateral views, MGUH 21.338. 5, 6, pygidia, MGUH 21.339 and 21.340 . 
as A. lophotus and A. exsulatus, anterior effacement of that furrow does not seem to warrant generic significance in acutatus. Therefore, I reassign the species to Agnostus and thereby suppress Acutatagnostus as a junior synonym. Other described species may warrant inclusion in Agnostus, but available morphological information, in my judgment, is equivocal.

Agnostus pisiformis is the only agnostoid for which appendages and soft anatomy are known (Müller \& Walossek, 1987). The fidelity of preservation in the illustrated Swedish specimens is extraordinary, providing far greater detail than is known for any other trilobite species. In the absence of comparable information from other agnostoids, however, taxonomic evaluation of the many characters of the appendages and other soft parts of Agnostus remains moot.

The species here included in Agnostus have a composite observed stratigraphic range from the Lejopyge laevigata Zone (upper Middle Cambrian) to the Pseudagnostus curtare Zone (middle Upper Cambrian). Cephala assigned here as Agnostus? cf. exsulatus are from the upper Ptychagnostus atavus Zone, but their generic assignment is open to question.

\section{Agnostus lophotus n. sp.}

Fig. 5

Etymology. Greek lophotos, crested; referring to the carinate glabella.

Holotype. Pygidium (Fig. 5.4a, b), MGUH 21.338 from GGU 301313.

Material. More than 40 disarticulated cephala and pygidia are in GGU 301312, 301313, and 313115.

Diagnosis. Glabella laterally swollen behind F3 and having thread-like median carina behind median node. Axis of pygidium, relatively short, tumid; F1 and F2 nearly effaced.

Description. Agnostus with preglabellar median furrow weakening forward. Anteroglabella short, anteriorly rounded or ogival. Transglabellar furrow (F3) bowed posteriorly. Posteroglabella with thread-like median carina extending rearward from median node, near midlength, to occipital band; F1 and F2 weak abaxially; M3 laterally swollen, resulting in greatest glabellar width just behind F3. Genae smooth or having weak, irregular, scrobicular pits. Pygidium with deep, sagittally wide, posteriorly bowed, articulating furrow. Axis tumid and relatively short, with terminal secondary node; F1 and F2 nearly effaced; median tubercle prominent, slightly elon- gate; posterior margin broadly rounded. Pleural fields fairly uniform in width laterally and posteriorly. Border furrow moderately wide on glabella, moderate to wide on pygidium.

Remarks. A. lophotus closely resembles A. neglectus Westergård (1946, p. 85, pl. 13, figs 7-9), but differs from that species by having a preglabellar median furrow that weakens forward, a pygidial axis that is broader, shorter, and with more effaced ring furrows, and the pleural fields are more uniform in width.

Occurrence. All specimens are from basal beds of the Kap Stanton Formation in Peary Land, and are from the lower Lejopyge laevigata Zone.

\section{Agnostus? cf. exsulatus Poulsen, 1960 Fig. 6}

Remarks. Two small cephala, one each in GGU 319789 and 319790 , resemble specimens of $A$. exsulatus Poulsen (1960, pl. 1, fig. 3; also Robison, 1988, fig. 7.5-8) by having a relatively short glabella and a preglabellar median furrow that weakens anteriorly. They differ, however, by having a narrower border furrow, straight rather than posteriorly bowed transglabellar furrow (F3), and more central placement of the median node on the posteroglabella. Whether these are ontogenetic or phylogenetic differences is difficult to judge from the small sample.

Occurrence. Both cephala are from the basal beds of the Kap Stanton Formation in Nyeboe Land, and from the upper Ptychagnostus atavus Zone. If further information, especially concerning the pygidium, supports assignment of this species to Agnostus, it will significantly extend downward the observed stratigraphic range of the genus.

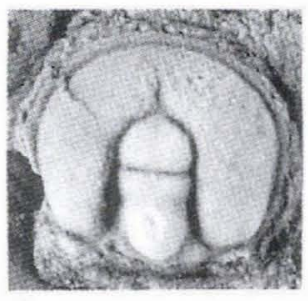

1

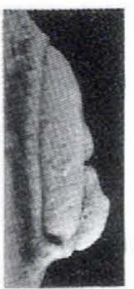

$2 a$

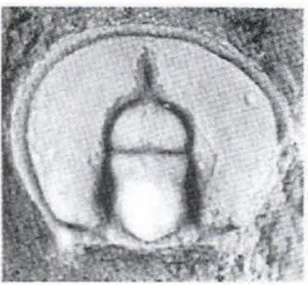

$2 b$
Fig. 6. Agnostus? cf. exsulatus Poulsen. 1, cephalon, MGUH 21.341 from GGU $319790, \times 15.2 a$, b, cephalon in lateral and dorsal views, MGUH 21.342 from GGU 319789, × 15 . 


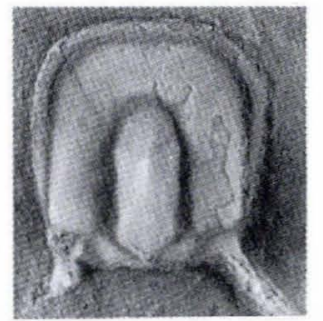

1

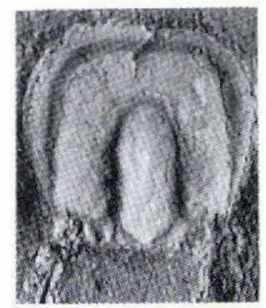

3

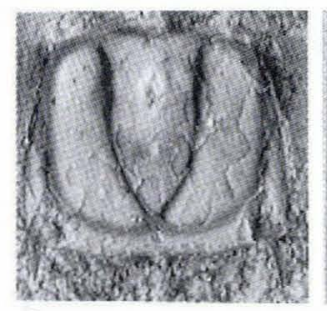

6

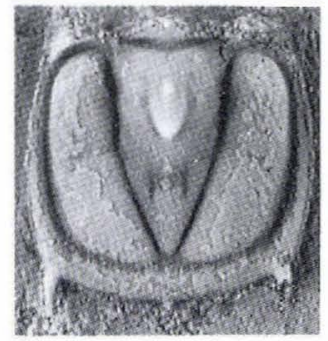

$8 a$

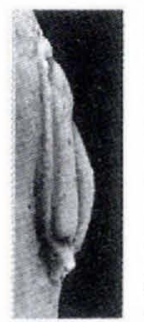

$2 a$

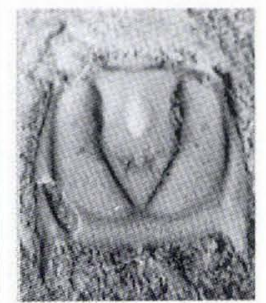

4

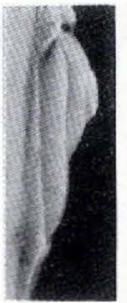

$9 b$

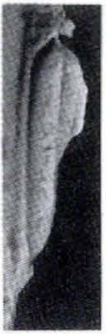

$8 b$

$2 b$

7

$9 a$
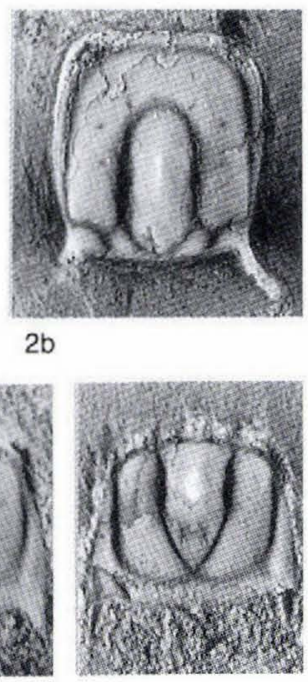

5
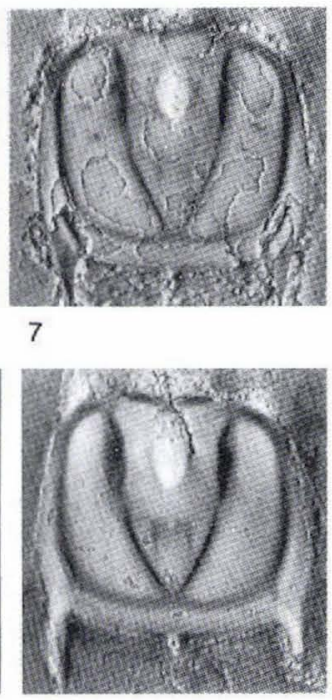

Fig. 7. Clavagnostus cf. milli Jago \& Daily. All specimens from GGU 301313, unless otherwise stated, and all $\times 10$. 1-3, cephala, MGUH 21.343-21.345. 4-7, 9, pygidia, MGUH 21.34621.350. 8, pygidium, MGUH 21.351 from GGU 313115.

Family Clavagnostidae Howell, 1937 Genus Clavagnostus Howell, 1937

Type species. Agnostus repandus Westergård in Holm \& Westergård 1930, pp. 13-15.

Remarks. Jago \& Daily (1974) have reviewed the taxonomy of Clavagnostus. Their emended generic diagnosis is followed here, with the exception that not all specimens have smooth genae. Some previously illustrated specimens (e.g., Jago \& Daily, 1974, pl. 11, figs 5-8, pl. 12, fig. 12) and some new specimens (Fig. 7) have weak

scrobicular depressions or pits both on genae of the cephalon and pleural fields of the pygidium.

\section{Clavagnostus cf. milli Jago \& Daily, 1974 Fig. 7}

Material. More than 40 specimens are in GGU 301312, 301313 , and 313115 .

Description of $G G U$ specimens. Cephalon subquadrate with pair of long, divergent, border spines. Genae confluent (preglabellar median furrow absent). Glabella undivided, rounded anteriorly, angular posteriorly; median node anterior, weak, and carinate; width of glabella greatest at level of node. Pygidium subquadrate; border trispinose with pair of moderate-sized posterolateral spines and one tiny median spine. Axis lanceolate, unfurrowed, extending to posterior border furrow; median node large, may have superimposed smaller node on anterior surface; transverse sulcus of posteroaxis having pair of elongate pits and one or two secondary nodes. Surfaces of genae and pleural fields smooth or with weak scrobicular pits.

Remarks. Specimens from North Greenland closely resemble those from Tasmania that Jago \& Daily (1974) assigned to Clavagnostus milli. They differ, however, in having a carinate node rather than a simple node on the glabella, and the tip of the pygidial axis is usually narrower. Jago \& Daily did not mention a medial spine on the pygidial border, but at least one of their specimens (pl. 11, fig. 15) appears to have the broken stub of such a spine. All illustrated specimens of $C$. milli are rather poorly preserved and are taphonomically deformed, making it difficult to evaluate the taxonomic significance of these differences. The Tasmanian and Greenland specimens seem to be of approximately the same age. Whether or not their minor differences represent only geographic variation within a single species is unclear.

Clavagnostus trispinus Zhou \& Yang (in Zhou et al., 1977; see also Yang, 1978, pp. 17-18, pl. 1, fig. 2) from the lower Lejopyge laevigata Zone of China, which has a tiny median spine on the pygidial border, may be a junior synonym of $C$. milli. Poor preservation of all illustrated specimens of both taxa, however, hampers taxonomic evaluation. Moreover, a cephalon of C. trispinus has not been illustrated.

The Greenland specimens also closely resemble those of $C$. repandus, but differ by having a more quadrate pygidium, a more acuminate pygidial axis, and an additional spine on the pygidial border.

Occurrence. All of the Greenland specimens are from 
Fig. 8. Diplagnostus planicauda (Angelin). 1, 2, cephala, MGUH 21.352 and 21.353, from GGU 301313, × 12 . 3, pygidium, MGUH 21.354 from GGU $298975, \times 10$.

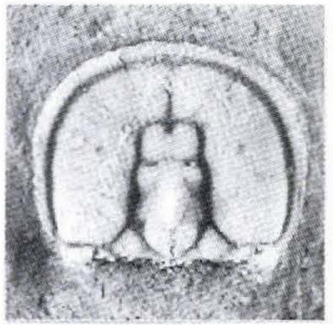

1

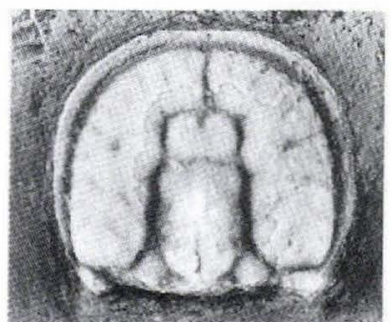

2

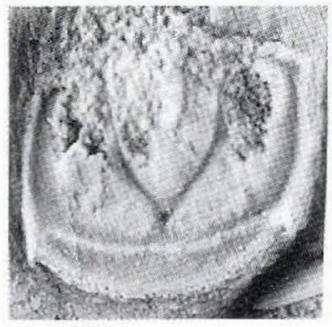

3 basal beds of the Kap Stanton Formation in Peary Land, and are from the lower Lejopyge laevigata Zone.

Family Diplagnostidae Whitehouse, 1936

Genus Diplagnostus Jaekel, 1909

Type species. Agnostus planicauda Angelin, 1851, p. 7.

\section{Diplagnostus planicauda (Angelin, 1851) Fig. 8}

New material. One pygidium is in GGU 298975, and 3 cephala and 1 pygidium are in GGU 301313.

Remarks. D. planicauda is a distinctive, geographically widespread, and stratigraphically long-ranging species. Its taxonomy was recently reviewed (Robison, 1988, pp. 33-35), and the new specimens add no new morphological information.

Lu \& Lin (1989, pp. 76-77, pp. 202-203, pl. 2, fig. 15, pl. 3, figs 1-8) recently described and illustrated specimens from western Zhejiang, China, that were assigned to Diplagnostus planicauda vestgothicus (Wallerius), D. zhexiensis Lu \& Lin, and D. floralis Öpik. Characters used to distinguish all these taxa fall within the range of variability observed within populations of $D$. planicauda, including ontogenetic series. Therefore, I consider the three taxa cited by Lu \& Lin (1989) to be junior synonyms of $D$. planicauda.

Occurrence. D. planicauda was recently reported to range from near the base of the Ptychagnostus punctuosus Zone to near the top of the Lejopyge laevigata Zone (Robison, 1988, p. 35). Occurrences recorded by Egorova et al. (1982), Lu \& Lin (1989), and Song (1989) indicate that the species actually ranges downward to at least the base of the Ptychagnostus atavus Zone. A representative pygidium of D. planicauda in GGU 298975 from Nyeboe Land (Fig. 8.3) is also from the $P$. atavus Zone. Other new specimens in GGU 301313 from Peary Land are from the $L$. laevigata Zone.
Genus Iniospheniscus Öpik, 1979

Type species. Iniospheniscus talis Öpik, 1979, pp. 50-51.

Remarks. Iniospheniscus is included in the Diplagnostidae with question because its pygidial border is not zonate, although medial expansion may indicate an incipient zonate condition. Also, compared with other genera in the family, the shape of its posteroaxis is unusual. The generic diagnosis of Shergold et al. (1990, p. 47) is followed here.

\section{Iniospheniscus incanus? Öpik, 1979}

Fig. 9.4

Remarks. A single, damaged pygidium in GGU 298969 from the upper Henson Gletscher Formation is assigned to Iniospheniscus. Its lateral margins converge slightly toward the posterior and it has a long, broad, pyriform axis that extends to the posterior border furrow. Its posterior border is medially widened. On the anteroaxis the F1 is weak, the F2 is effaced, and the median tubercle is large and elongate. The posteroaxis is laterally expanded and subpentagonal in outline. The acrolobe is slightly constricted, the border furrow is wider laterally than it is posteriorly, and the border has a pair of small posterolateral spines. These characters are similar to those of I. incanus Öpik (1979, p. 51, pl. 9, figs 8, 9) from Australia, but the pygidial axis is slightly broader and the lateral borders are narrower. Assignment of the new pygidium to $I$. incanus is questioned, primarily because information about the entire exoskeleton is limited. The new pygidium is from the Ptychagnostus atavus Zone, as are all described specimens of $I$. incanus.

\section{Genus Linguagnostus Kobayashi, 1939}

Type species. Agnostus kjerulfi Brøgger, 1878, pp. 49-50.

Remarks. The generic diagnosis of Shergold et al. (1990, pp. 47-48) is followed here. 


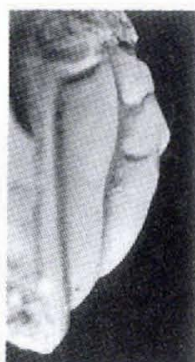

$1 \mathrm{a}$

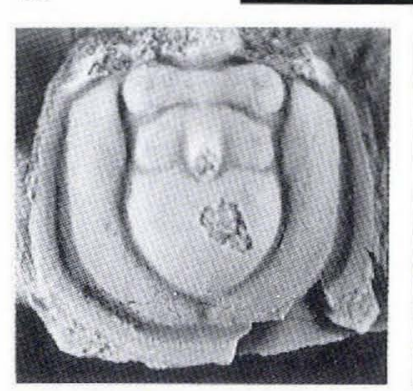

$1 \mathrm{~b}$

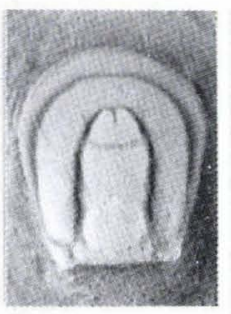

2

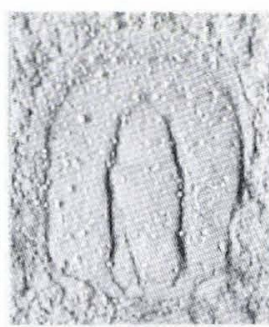

3

Linguagnostus groenwalli Kobayashi, 1939

Fig. 10

Agnostus kjerulfi Brøgger, Grönwall, 1902, pp. 69-70, pl. 1, fig. 11

Linguagnostus kjerulfi forma grönwalli, Kobayashi, 1939, pp. 142-143

Linguagnostus grönwalli Kobayashi, Westergård, 1946, pp. 63-64, pl. 8, figs 30a, b; Pokrovskaya in Chernysheva, 1960 pl. 1, fig. 5; Egorova, Pegel \& Chernysheva in Egorova et al. 1982, p. 62 , pl. 12 , fig. 3 , pl. 14 , fig. 6 , pl. 16, figs 11,12

New material. Four cephala and 6 pygidia are in GGU 319789 and 319790.

Emended diagnosis. Cephalon having narrow border and very wide, shallow border furrow; acrolobe unconstricted. Glabella broad, subcylindrical; width of anteroglabella about twice its length; F3 shallow, narrow, straight or slightly bowed rearward; posteroglabella with carinate median node anterior from midpoint. Thorax having wide axis. Pygidium zonate in late holaspid period; collar thread-like, bowing forward onto posterior border furrow. Acrolobe constricted and bordered posteriorly by narrow sinuous ridge that fades posterolaterally into prong-like projections extending toward border spines. Axis broad; F1 and F2 mostly effaced; anteroaxis subquadrate with carinate tubercle mostly confined to M2; posteroaxis having well-developed transverse sulcus and associated secondary median node near anterior margin, part behind sulcus reduced to small triangular vestige. Pleural fields narrow between axis and posterior border furrow, having pair of low, transversely elongate swellings that may be separated by postaxial depression

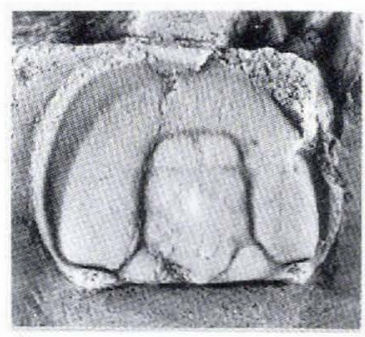

1

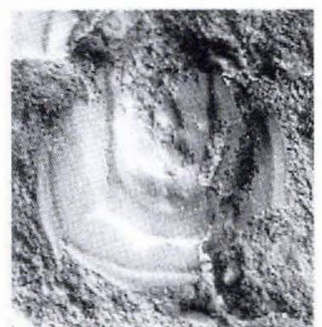

4

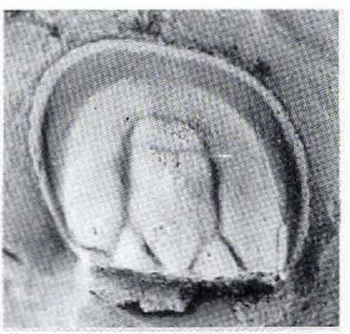

2

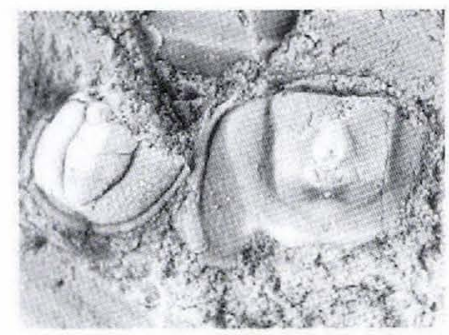

5

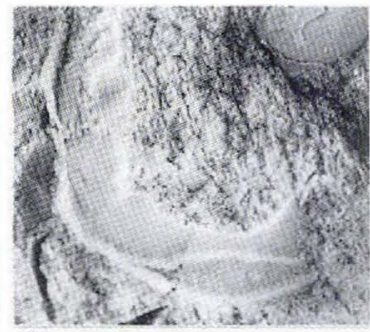

3

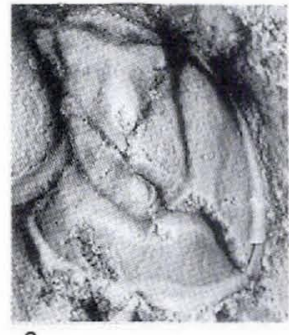

6
Fig. 10. Linguagnostus groenwalli Kobayashi. 1, cephalon, MGUH 21.359 from GGU $319790, \times 5.5 .2$, cephalon from MGUH 21.360 from GGU $319789, \times 6.3$, incomplete pygidium, MGUH 21.361 from GGU $319790, \times 6$. 4, latex cast of pygidium, MGUH 21.362 from GGU $319789, \times 6.5$, incomplete pygidium associated with smaller pygidium of Ptychagnostus affinis (left), MGUH 21.363 from GGU $319790, \times 6.6$. deformed pygidium. MGUH 21.364 from GGU 319790, × 6 . 
or furrow. Pygidial border furrow very wide, shallow, and irregular in width; border narrow, bispinose.

Remarks. The few new specimens of this species are fragmentary or deformed, or both. Nevertheless, their number and condition is sufficient to demonstrate most characters of the cephalon and pygidium. Such diagnostic characters of the pygidium as advanced effacement of ring furrows, a carinate tubercle mostly confined to the second ring, shape of the acrolobe, and a pair of low swellings between the axis and posterior border furrow, closely match those of rare and small specimens of Linguagnostus groenwalli from Scandinavia (Westergård, 1946, pp. 63-64). Most of the pygidia from Greenland are larger than those previously described from Scandinavia, however, and have a shallow postaxial depression rather than a median furrow, a wider border furrow, and a pygidial collar (sensu Öpik, 1967, p. 62). All of these differences are likely to be of ontogenetic origin, and the new specimens are therefore assigned to $L$. groenwalli.

In discussing Linguagnostus, Öpik $(1979$, p. 52) concluded that $L$. groenwalli "is an aberrant form with a nonzonate pygidium" that "cannot be convincingly accommodated in this [Linguagnostus] or any other genus of Diplagnostidae." With the discovery in Siberia (Egorova et al., 1982, pl. 14, fig. 6) and Greenland of larger specimens having a zonate pygidial border, $L$. groenwalli now accords well with a recent diagnosis of Linguagnostus (Shergold et al., 1990, pp. 47-48). As size increases, the larger holaspid pygidia show progressively greater separation of the posterior border and the narrow but distinct collar (Fig. 10.3, 4, 6). Comparison of new specimens indicates that the ontogenetic appearance of a collar in L. groenwalli was delayed until the middle of the holaspid period.

The transverse ridge on the posterior border furrow of $L$. groenwalli (Fig. 10.3, 4, 6) and the ridge separating the posterior acrolobe and border furrow of $L$. kjerulfi (e.g., Westergård, 1946, pl. 8, fig. 32) both fall within the definition of a pygidial collar (sensu Öpik, 1967, p. 62; Shergold et al., 1990, p. 16). Two separate ridges on pygidia in Fig. 10.4 and 10.6 demonstrate that some ridges previously identified as pygidial collars are not homologous. Better preserved specimens should help to evaluate the relationship and significance of these ridges.

Occurrence. L. groenwalli has been reported from the Ptychagnostus punctuosus Zone of Denmark and Sweden, as well as approximately correlative levels in the Anapolenus Zone of Russia (Siberia). New specimens from Greenland are all from the basal beds of the Kap Stanton Formation in Nyeboe Land, and are from the upper Ptychagnostus atavus Zone.

\section{Family Doryagnostidae Shergold et al., 1990}

Emended diagnosis. Agnostoids with preglabellar median furrow variably developed. Border furrow may expand as small triangular depression (deltoid area) at junction with preglabellar median furrow. Axial furrow well developed. Glabella cylindrical to slightly tapered, unequally divided by transglabellar furrow (F3), rounded posteriorly. Basal lobes simple. Genae smooth. Pygidium axiolobate and simplimarginate. Axis terminating short of posterior border furrow; $F 1$ and F2 undeveloped or weakly developed only near axial furrow. Anteroaxis with node on M2. Posteroaxis lanceolate to weakly ogival, commonly with acuminate tip; transverse sulcus and secondary node appearing during phylogeny. Postaxial median furrow present. Margin of pygidium rounded posteriorly, bispinose. Cephalic and pygidial border furrows of moderate width.

Remarks. The subfamily Doryagnostinae was erected by Shergold et al. (1990, p. 44), who assigned it to the family Spinagnostidae Howell, 1935a. From review of the type collection of Spinagnostus franklinensis Howell, 1935a, the type species of Spinagnostus, it is noted that the specimens are from multiple localities, all are disarticulated, and all are poorly preserved. In my opinion, the specimens lack diagnostic characters for differentiation at the generic and family level, and a question about the correct association of disarticulated parts is open. Therefore, I consider both Spinagnostus and Spinagnostidae to be unrecognisable taxa.

As emended below, the inferred ancestral species of Doryagnostus, D. vinicensis (Šnajdr, 1957), seemingly evolved from Peronopsis gaspensis Rasetti, 1948 by development of a preglabellar median furrow (Robison, 1978). A similar furrow, apparently from iterative evolution, is also present in such genera as Agnostus and Ptychagnostus. Based on the inferred phylogeny of Doryagnostus, I concur with Shergold et al. (1990) in assigning it to a separate family-group taxon, but I here elevate it from subfamily to family rank. Such rank corresponds to that of the Ptychagnostidae, which is inferred to have arisen from Peronopsis brighamensis Resser, 1939 by independent evolution of a preglabellar median furrow (Robison, 1978).

Without discussion, Shergold et al. (1990, pp. 44-45) assigned Doryagnostus Kobayashi, 1939, Itagnostus Öpik, 1979, and Rhodotypiscus Öpik, 1979 to their Doryagnostinae. Of these genera, I consider Itagnostus to be a junior synonym of Peronopsis. The type species of Itagnostus, Agnostus elkedraensis Etheridge, 1902, lacks any reported evidence of a preglabellar median furrow. 
Moreover, it differs from Peronopsis montis (Matthew, 1899 ) by only its slightly more posterior median node on the glabella and slightly more quadrate cephalon and pygidium. Whether these differences are genotypic or phenotypic is problematic, but in my opinion they lack generic significance. An emended diagnosis of Peronopsis is given below, which is broader in concept than that of Shergold et al. (1990). The type species of Rhodotypiscus, $R$. nasonis Öpik, 1979 has an incomplete preglabellar median furrow. A preglabellar median furrow is variably developed in Doryagnostus vinicensis (Šnajdr, 1957, emended below), and commonly it is incomplete in some populations (e.g., Robison, 1978, pp. 8-9). All other characters of $R$. nasonis are shared with representative species of Doryagnostus, and Rhodotypiscus is therefore suppressed as a subjective junior synonym. With these taxonomic emendations, Doryagnostus is the only genus presently assigned to the Doryagnostidae.

Doryagnostids can usually be distinguished from furrowed ptychagnostids by lesser development of pygidial ring furrows. Also, some doryagnostids have a deltoid area on the cephalon, which is absent on ptychagnostids. Effacement of furrows on the acrolobes is a common evolutionary trend in ptychagnostids, but has not been reported in doryagnostids.

\section{Genus Doryagnostus Kobayashi, 1939}

Doryagnostus Kobayashi, 1939, p. 148; Robison, 1978, p. 5 (synonymy to date); Öpik, 1979, pp. 81-82; Shergold et al., 1990, pp. 44-45

Ceratagnosius Whitehouse, 1939, pp. 255-256

Rhodotypiscus Öpik, 1979, p. 79; Shergold et al., 1990, p. 45

Type species. Agnostus incertus Brøgger, 1878, pp. $70-71$.

Emended diagnosis. As for family.

Remarks. Species here included in Doryagnostus are D. incertus (Brøgger, 1878) ( = Ceratagnostus magister Whitehouse, 1939), D. vinicensis (Šnajdr, 1957; see synonymy below), $D$. deltoides Robison in Jell \& Robison, 1978 ( = D. notalibrae Öpik, 1979), D. nasonensis (Öpik, 1979), D. solidus Öpik, 1979, D. sayramhuensis (Zhang, 1981), and D. sectilis Xiang \& Zhang, 1985. Reasons for and against the synonymy of $D$. incertus and $D$. magister have been discussed by Robison (1978, p. 7) and Nikolaisen \& Henningsmoen (1990, p. 61).

Öpik (1979, p. 82) observed that a species of Doryagnostus, possibly new, is present in Utah, and is represented by some specimens that I previously illustrated (Robison, 1964, pl. 79, figs 8, 11) as ?Ptychagnostus sp. and Ptychagnostus hybridus. I concur, but a search for additional specimens has not been successful.

\section{Doryagnostus vinicensis (Šnajdr, 1957)}

Fig. 11

Ptychagnostus (Triplagnostus) vinicensis Šnajdr, 1957, p. 235, pl. 1, fig. 1; Šnajdr, 1958 (in part), pp. 71-72, pp. 243-244, pl. 4, figs 21, ?22 (not pl. 4, figs 19, 20, 23, 24)

Doryagnostus wasatchensis Robison, 1978, pp. 8-9, pl. 1, figs $1-4,6$; pl. 2, figs $6,9-13$

Triplagnostus vinicensis (Šnajdr), Fatka et al., 1981, pp. 367368 , pl. 1, fig. 1, pl. 2, figs 6, 7

Doryagnostus vinicensis (Šnajdr), Fatka \& Kordule, 1992, pl. 2, fig. 4

New material. More than 20 disarticulated cephala and pygidia are in GGU 298970.

Emended diagnosis. Doryagnostus having relatively broad glabella, its width being about equal to or slightly greater than that of adjacent genae at level of F3. Anteroglabella large and broadly rounded to obtusely pointed at front. Posteroglabella tumid at rear, with median node behind midpoint. Pygidium characterised by small border spines. Posteroaxis lanceolate to slightly ogival, and usually without transverse sulcus.

Remarks. Several new specimens from North Greenland

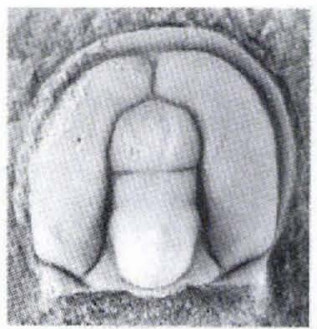

1a

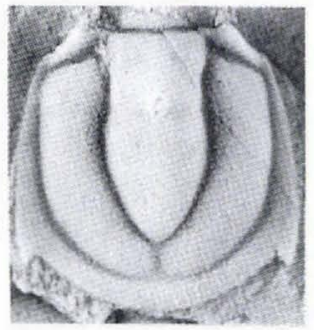

$3 a$

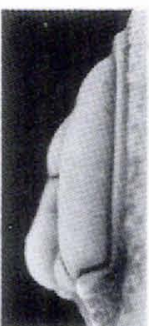

$1 b$

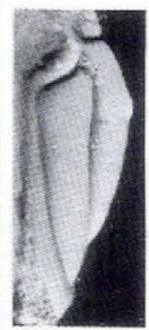

$3 b$

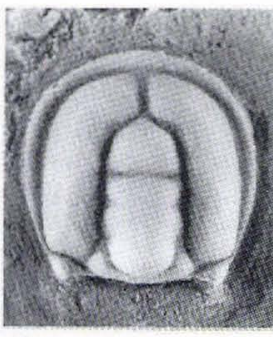

2

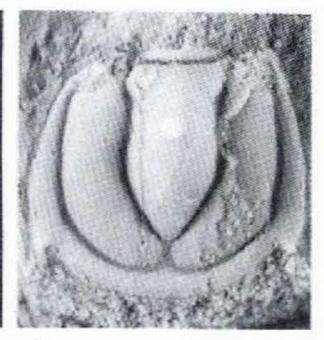

4
Fig. 11. Doryagnostus vinicensis ( $\breve{n a j d r) . ~ A l l ~ s p e c i m e n s ~ f r o m ~}$ GGU 298970 and all $\times 8$. 1, cephalon in dorsal and lateral views, MGUH 21.365. 2, cephalon, MGUH 21.366. 3, pygidium in dorsal and lateral views, MGUH 21.367. 4, pygidium, MGUH 21.368 . 
have characters that accord closely with the emended diagnosis of $D$. vinicensis.

The original description of Ptychagnostus (Triplagnostus) vinicensis was confused because it was based in part on a holotype cephalon of Doryagnostus and in part on pygidia of Lejopyge hybridus, as here reassigned. With the aid of additional specimens, some complete, that erroneous association of sclerites was recognised by Fatka et al. (1981), but the species was assigned to Triplagnostus. In subsequent discussion of new localities by Fatka \& Kordule (1992), however, the species was reassigned without taxonomic comment to Doryagnostus.

Doryagnostus wasatchensis Robison, 1978, which was described from Utah, is now considered to be a subjective junior synonym of $D$. vinicensis. Minor differences between the type specimens of these taxa seem to have been accentuated by taphonomic processes. On one hand, the illustrated specimens from Czechoslovakia are preserved as moulds in shale and show internal features of the exoskeleton. On the other hand, the illustrated specimens from Utah are preserved in limestone and show external features of the exoskeleton.

The preglabellar median furrow is variably developed in observed populations from Utah, but is uniformly present in known specimens from Czechoslovakia and Greenland. The more variable specimens from Utah are inferred to represent an earlier stage of phylogeny.

Occurrence. The new specimens are from the middle Henson Gletscher Formation, and are from the Ptychagnostus gibbus Zone. The species has been reported elsewhere from the Eccaparadoxides pusillus Zone of Czechoslovakia and the upper $P$. gibbus Zone of the United States (Utah).

\section{Family Metagnostidae Jaekel, 1909 Genus Diplorrhina Hawle \& Corda, 1847}

Diplorrhina Hawle \& Corda, 1847, pp. 46-47; Lermontova, 1940, p. 123; Öpik, 1967, pp. 75-76; Pek \& Vaněk, 1971, pp. 271-272; Shergold et al., 1990, p. 46

Mesospheniscus Hawle \& Corda, 1847, p. 46

Quadragnostus Howell, 1935a, p. 219; Howell in Harrington et al., 1959, p. O186; Shaw, 1966, p. 849; Shergold et al., 1990 , p. 56

?Pseudoperonopsis Harrington, 1938, p. 151; Shergold et al., 1990, p. 45

Type species. Diplorrhina triplicata Hawle \& Corda, 1847 , p. 47 ; subsequent designation by Pek \& Vaněk, 1971, p. 271 [ = Battus cuneifer Barrande, 1846, p. 18].

Emended diagnosis. Cephalon commonly subquadrate.
Glabella subcylindrical, length about two-thirds that of cephalon, broadly angular at posterior; F3 well developed to effaced, bowed rearward if developed, commonly weakening abaxially. Anteroglabella short, subcircular to elliptical. Posteroglabella laterally swollen at anterior M3, slightly constricted at F2; median node near anterior edge of M2. Basal lobes simple, anteriorly indenting glabella. Genae confluent, smooth to scrobiculate. Thorax unmodified. Pygidium axiolobate and simplimarginate; width greater than length. Axis moderately long to long; F1 and F2 weak or effaced; median tubercle moderate in size, commonly elongate. Posteroaxis, if elongate, having weak transverse sulcus and secondary median node. Pleural fields smooth. Border flat, widening posterolaterally into pair of marginal spines.

Remarks. The generic names Diplorrhina and Mesospheniscus, here considered to be synonyms, were first published on the same page by Hawle \& Corda (1847, p. 46). Eleven species were assigned to Diplorrhina by Hawle \& Corda (1847, pp. 47-50), and from these Pek \& Vaněk (1971, p. 271) subsequently designated $D$. triplicata as the type species. The type species of Mesospheniscus by monotypy is Battus cuneifer Barrande, 1846. Lectotypes for both $D$. triplicata and $B$. cuneifer were selected by Šnajdr (1958, pl. 3, fig. 9 and pl. 2, fig. 30, respectively), but he reassigned cuneifer to Peronopsis, and he listed triplicata as a junior synonym of $P$. cuneifer. Genal surfaces of specimens illustrated by Šnajdr as $P$. cuneifer vary from smooth to moderately scrobiculate, which he attributed to 'pelomorphic' deformation (compare Pek \& Vaněk, 1971, p. 271). After further study of the same specimens, Pek \& Vaněk (1971) reassigned those with smooth genae to Peronopsis cuneifer and those with scrobiculate genae to Diplorrhina triplicata.

New specimens from North Greenland have characters similar to those of specimens illustrated by Šnajdr (1958) as Peronopsis cuneifera, including genae that grade from smooth to moderately scrobiculate (see Fig. 12.1-5). Such scrobiculation is here judged to be a primary character rather than a secondary condition resulting from taphonomic processes. Therefore, based on the apparent variability in scrobiculation, in combination with shared characters of the axial lobe and borders, I agree with Šnajdr (1958) that D. triplicata Hawle \& Corda, 1847 is a junior synonym of Battus cuneifer Barrande, 1846.

Some authors, including myself (Robison, 1964, p. 529), have previously considered Diplorrhina and Mesospheniscus to be synonyms of Peronopsis. Based on new material and further analysis, I now consider Diplorrhina and Mesospheniscus to be synonyms because of the synonymy of their type species, but not synonyms of Peronopsis. Because such taxonomy has not been previously 
suggested, I follow the Principle of the First Reviser (International Code of Zoological Nomenclature, 1985, Article 24) and here select Diplorrhina to have precedence as the senior synonym. This choice is influenced by the fact that the lectotype of $D$. triplicata, the type species of Diplorrhina, is a complete holaspid (Šnajdr, 1958 , pl. 4, fig. 9) with a full complement of differential characters. In comparison, the lectotype of Battus cuneifer Barrande, the type species of Mesospheniscus, is a meraspid stage 0 instar (Šnajdr, 1958, pl. 3, fig. 30) with few differential characters.

Diplorrhina, as emended, is characterised by a posteriorly bowed glabellar F3, anterolateral swelling of the glabellar M3, and a flattened, posterolaterally expanded, spinose pygidial border. All of these characters may be weakly developed or absent in early instars, and were generally accentuated during ontogeny. Length of the pygidial axis seems to have increased during phylogeny, commonly reaching almost to the posterior border furrow. With elongation, the posteroaxis developed a weak transverse sulcus with a secondary median node. Size of the pygidial spines also increased during phylogeny, primarily by increase in basal width. Expression of segmental furrows on the axial lobe and development of genal scrobiculation are both variable.

Among species here assigned or reassigned to Diplorrhina are Battus cuneifer Barrande, 1846, Agnostus quadratus Tullberg, 1880, Quadragnostus solus Howell, 1935a, Peronopsis cylindrica Westergård, 1946, Peronopsis scaphoa Öpik, 1961, and Diplorrhina oncota $\mathrm{n}$. sp. Other representatives of Diplorrhina are $D$. redita Pek \& Vaněk, 1971 (pp. 274-275, pl. 1, figs 4, 5), which may be a junior synonym of $D$. cuneifer, and Peronopsis fallax depressa Westergård, 1946 (pp. 27-38, pl. 2, figs 25, 26), which may be a junior synonym of $D$. cylindrica. The origin of Diplorrhina is unclear, but comparative morphology and stratigraphic ranges suggest that it arose by cladogenesis from either Peronopsis fallax or Peronopsis ferox.

Specimens of $Q$. solus Howell, the type species of Quadragnostus Howell, 1935a, have been previously illustrated with only retouched photographs (Howell, 1935a, pl. 22, figs 6, 7; Howell in Harrington et al., 1959, fig. $126.6 \mathrm{a}, \mathrm{b})$ that convey false information about characters. The same specimens, which include the holotype pygidium and a paratype cephalon, are illustrated here with unaltered photographs (see Fig. 13). Although poorly preserved, these specimens appear to possess the differential characters of Diplorrhina, and therefore $Q u a$ dragnostus is considered to be a junior synonym.

Another species of Diplorrhina seems to be represented by poorly preserved specimens having a slightly shorter pygidial axis than do the species mentioned above. Some such specimens from France have been assigned to Peronopsis sallesi (Munier-Chalmas \& Bergeron) by Howell (1935b, pp. 226-227, pl. 22, figs 17 , 18?). Other specimens from Spain and France have been assigned to Peronopsis fallax sallesi by Sdzuy (1961, pp. $523-524$, pl. 2, figs 1-8), Courtessole (1973, pp. 116117, pl. 2, figs 4-14), and Gil Cid (1981, pp. 118-119). Similar specimens from northern Norway have been assigned to Peronopsis ferox sallesi by Nikolaisen \& Henningsmoen (1990, pp. 57-59, fig. 6.A-G). Although most of these specimens appear to represent Diplorrhina, the species name is in question because the type specimen of Agnostus sallesi Munier-Chalmas \& Bergeron in Bergeron, 1889 is assumed to be lost (Laurie, 1990, p. 319). This has further taxonomic implications because $A$. sallesi is the type species of Pseudoperonopsis Harrington, 1938. The taxonomic affinity of Pseudoperonopsis is therefore difficult to evaluate without more knowledge about characters of the type specimen of A. sallesi, and the genus is listed here as a questionable synonym of Diplorrhina.

Most characters of Diplorrhina are closely similar to those of the Metagnostidae (sensu Fortey, 1980, pp. 24 29) of Ordovician age. A notable exception is the longer axis on the pygidium of Diplorrhina. Based on these similarities, I suggest that the metagnostids may have originated from Diplorrhina, and that one change in the transitional lineage was reduction of the posteroaxis behind the transverse sulcus. More information from Late Cambrian agnostoids is needed to test this hypothesis. In the meantime, Diplorrhina is questionably assigned to the Metagnostidae as its ancestral genus. Variable development of genal scrobiculation in Diplorrhina may be significant because metagnostids are the only Ordovician agnostoids having that character.

Diplorrhina, as emended, is known from Czechoslovakia, Sweden, Norway, Denmark, England, France, Spain, Russia (Siberia), Australia (Queensland), the United States (Vermont), Canada (eastern Newfoundland), and Greenland. It has an observed stratigraphic range from the Ptychagnostus atavus Zone to the lower Lejopyge laevigata Zone, and questionably from the upper Ptychagnostus gibbus Zone.

\section{Diplorrhina oncota $n$. sp.}

Fig. 12

Etymology. Greek onkotos, swollen; referring to the anterolateral swelling of the glabellar M3.

Holotype. Cephalon (Fig. 12.1a-c), MGUH 21.369 from GGU 301313. 
Fig. 12. Diptorrhina oncota n. sp. All specimens from GGU 301313 and all $\times 10$, unless otherwise stated; relative width of the pygidia has probably been accentuated by taphonomic compression. 1, holotype cephalon in dorsal (a, b, stereogram) and lateral (c) views, MGUH 21.369. 2, 4, 5 cephala, MGUH 21.370-21.372. 3, cephalon, MGUH 21.373 from GGU 313115, x 8.6, 8. pygidia, MGUH 21.374 and 21.375 from GGU 313115. 7, pygidium, MGUH 21.376.

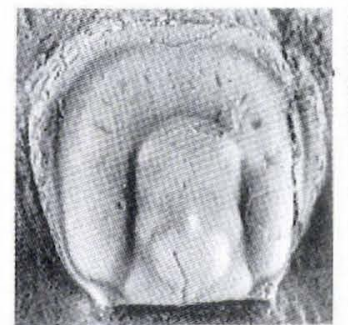

$1 \mathrm{a}$

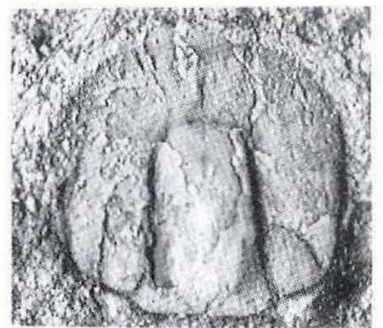

3

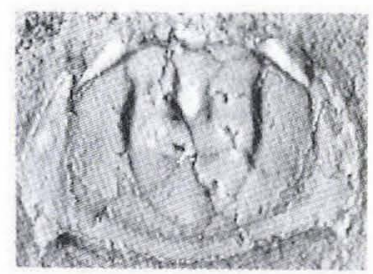

6

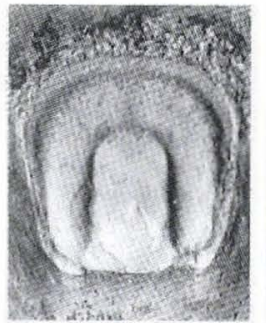

2

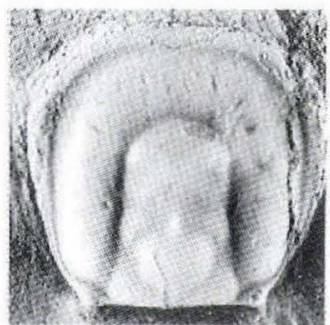

$1 b$

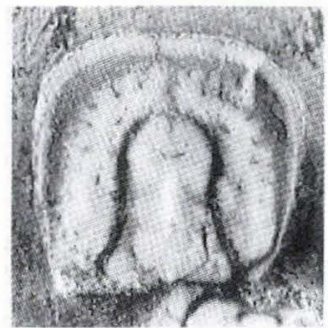

4

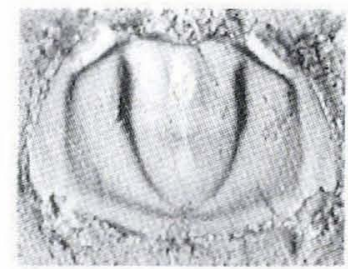

7

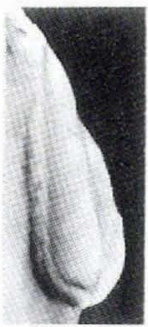

$1 \mathrm{c}$

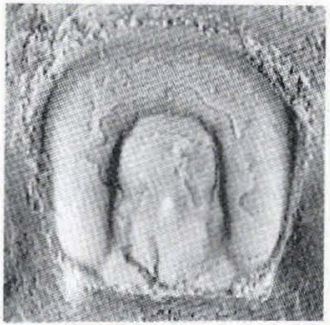

5

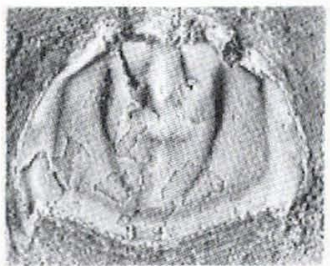

8
Material. More than 20 specimens are in GGU 301313 and 313115 .

Diagnosis. Diplorrhina with glabellar F3 effaced or with only medial development, and M3 prominently swollen at anterolateral corners. Genae smooth to moderately scrobiculate. Pygidium wider than long; axis subcylindrical forward of transverse sulcus, but weakly constricted at $\mathrm{M} 2 ; \mathrm{F} 1$ and F2 mostly effaced; posteroaxis tapers to broadly rounded point behind transverse sulcus. Lateral pygidial borders unusually wide and flat.

Remarks. D. oncota most closely resembles $D$. cuneifer (Šnajdr, 1958, pl. 3, figs 13-37, pl. 4, figs 1-11) and $D$. cylindrica (Westergård, 1946, pl. 3, figs 17-21) but differs from both by having a smaller anteroglabella, common effacement of the glabellar F3, and greater effacement of ring furrows on the pygidium. D. cuneifer mainly differs from $D$. cylindrica by having more scrobiculae and a larger median tubercle on the pygidium.

D. solus (Howell, 1935a) is based on poorly preserved specimens (Fig. 13) that differ little from those of $D$. quadrata (Tullberg, 1880), and D. solus may be a junior synonym. Those two taxa are easily differentiated from
D. oncota by their more evenly tapered pygidial axis and better developed glabellar F3.

Occurrence. All specimens of $D$. oncota are from basal beds of the Kap Stanton Formation in Peary Land, and are from the lower Lejopyge laevigata Zone.

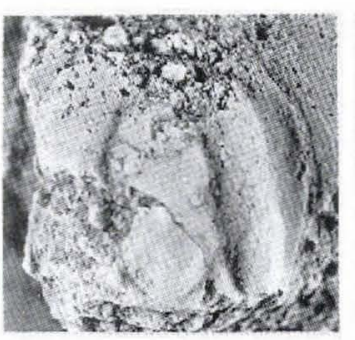

1

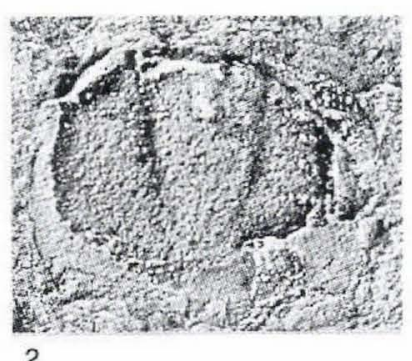

Fig. 13. Diplorrhina solus (Howell) from the St. Albans Shale of Vermont. 1, paratype cephalon, Princeton University no. 40126, $\times 5$. 2, holotype pygidium, Princeton University no. 9793, $\times 5$. 


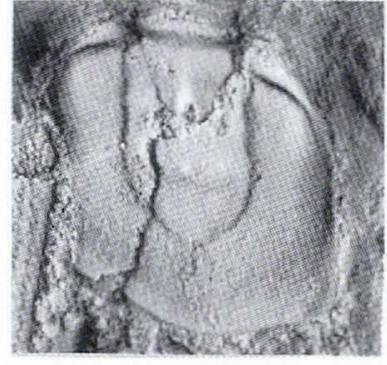

1

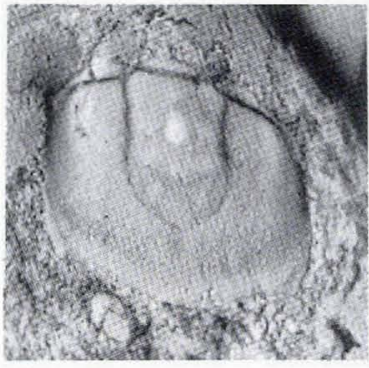

2

Fig. 14. Diplorrhina cf, sallesi (Munier-Chalmas \& Bergeron) from GGU 319789. 1, 2, pygidia, MGUH 21.377 and 21.378, both $\times 8$.

\section{Diplorrhina cf. sallesi (Munier-Chalmas \& Bergeron in Bergeron (1889) \\ Fig. 14}

Remarks. The taxonomy of $D$. sallesi, as reassigned here, has been recently reviewed by Nikolaisen \& Henningsmoen (1990, pp. 57-59), who referred the taxon to Peronopsis ferox sallesi. Two pygidia in GGU 319789 closely resemble those previously assigned to the taxon (for synonymy, see Nikolaisen \& Henningsmoen, 1990, pp. 57-58), but their assignment to genus and species is open to question in the absence of associated cephala. Although seemingly affected by taphonomic compression, the two pygidia show the characteristic axial form of $D$. sallesi and such other features as effaced ring furrows, moderate-sized median tubercle, sulcate posteroaxis, and robust border spines (indicated by broken stubs). The specimens are from basal beds of the Kap

Stanton Formation in Nyeboe Land, and are from the upper Ptychagnostus atavus Zone.

Family Peronopsidae Westergård, 1936 Genus Hypagnostus Jaekel, 1909

Type species. Agnostus parvifrons Linnarsson, 1869, p. 82.

\section{Hypagnostus brevifrons (Angelin, 1851)}

Fig. 15

Agnostus brevifrons Angelin, 1851, p. 6, pl. 6, fig. 4; Brøgger, 1878, pp. 57-58, pl. 6, fig. 10; Tullberg, 1880, pp. 35-36, pl. 2, fig. 29a, b; Grönwall, 1902, p. 76

Metagnostus brevifrons (Angelin), Jaekel, 1909, p. 399

Hypagnostus brevifrons (Angelin), Whitehouse, 1936, p. 104; Kobayashi, 1939, p. 123, 125; Whitehouse, 1939, pp. 263264: Westergård, 1946, pp. 48-49, pl. 5, figs 24-29; Öpik, 1961, pp. 58-59, pl. 18, figs 6-10; Wang et al., 1963, p. 27 , pl. 2, figs 12-15; Lu et al., 1965, pp. 44 45, pl. 4, figs 21-24; Khajrullina, 1970, p. 13, pl. 1, fig. 2; Khajrullina, 1973, pp. 42-44, pl. 2, figs 6, 9, 11, 12; Repina et al., 1975, p. 116, pl. 10, figs 7-10, pl. 11, figs 1-3; Rosova, 1977, p. 166, pl. 23, figs 9-12; Ergaliev, 1980, pl. 4, figs 9-11; Yang, 1982, pl. 2, figs 6, 7; Egorova, Pegel \& Chernysheva in Egorova et al., 1982, p. 70, pl. 18, fig. 5, pl. 21, figs 3, 5, pl. 34, fig. 17, pl. 46, fig. 2a; Xiang \& Zhang, 1985, p. 67, pl. 17, figs 11, 12; Lu \& Lin, 1989, pp. 106-107, 223, pl. 11, figs 1, 2

Cyclopagnostus brevifrons (Angelin), Howell, 1937, p. 1166; Öpik, 1979, p. 66

Hypagnostus brevifrons vulgarus Qian \& Qiu in Qiu et al., 1983 , p. 41 , pl. 14 , figs 5,6
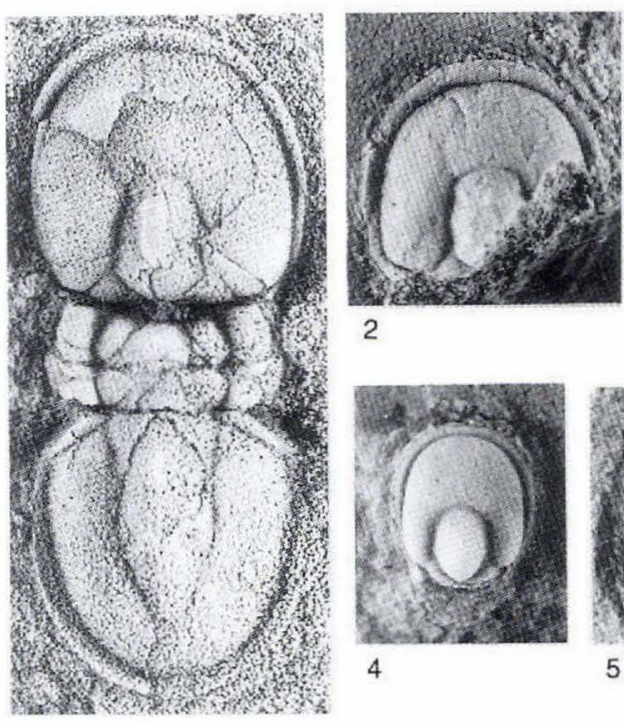

2

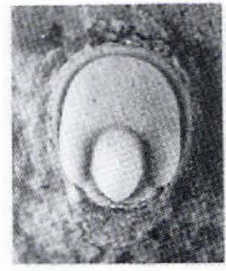

4

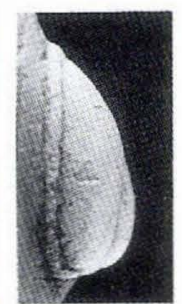

$3 a$

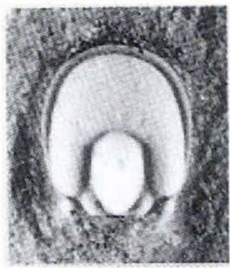

5

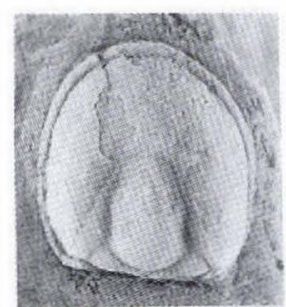

$3 b$

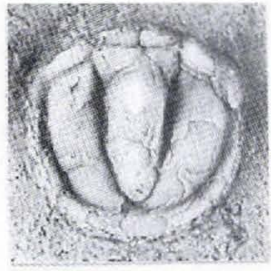

6
Fig. 15. Hypagnostus brevifrons (Angelin). All specimens from GGU 313115 , unless stated otherwise. 1, dorsal exoskeleton, MGUH 21.379, $\times 5.2$, incomplete cephalon, MGUH $21.380, \times 10.3 \mathrm{a}, \mathrm{b}$, cephalon in lateral and dorsal views, MGUH $21.381, \times 8.4$, cephalon, MGUH $21.382, \times 15.5$, cephalon, MGUH 21.383 from GGU 301313, $\times$ 15. 6 , pygidium, MGUH 21.384, × 10 . 
New material. Thirteen specimens are in GGU 301312 , 301313 , and 313115.

Emended diagnosis. Hypagnostus with short, anteriorly tapering remnant glabella; length less than half that of cephalon. Pygidial axis unfurrowed, well separated from posterior border furrow in late holaspid period; posteroaxis varies from subcylindrical with broadly rounded rear to moderately tapered. Pleural fields confluent in larger holaspides. Posterior border uniform in width.

Remarks. $H$. brevifrons differs from $H$. parvifrons, the type species of Hypagnostus, by its shorter pygidial axis in the late holaspid period and by lacking a medial expansion of the posterior border. Also, its glabella is usually more tapered.

The new specimens from Greenland have a considerable range in holaspid size and show some related changes in morphology. For example, the anterior glabella usually is more tapered on larger holaspid cephala (compare Fig. 15.1-5). On the pygidium, the axis extends almost to the posterior border furrow on smaller holaspides (Fig. 15.6), but is well separated on large holaspides (Fig. 15.1).

Howell (1937) described Cyclopagnostus hesperius as a new genus and new species. At the same time, he reassigned Agnostus brevifrons Angelin to Cyclopagnostus, and both taxa were assigned to the new subfamily Cyclopagnostinae and new family Cyclopagnostidae. Soon after, Kobayashi (1939, pp. 123, 127-128) suppressed Cyclopagnostus as a junior synonym of Hypagnostus. That synonymy has been generally accepted, although Howell in Harrington et al. (1959, p. O175) and Öpik (1979, p. 66), both without explanation, continued to recognise Cyclopagnostus as a valid genus. For comparison with $H$. brevifrons, the type specimens of $C$. hesperius are here reillustrated with photographs that are not retouched (Fig. 16). From review of these types, I conclude that the holotype of C. hesperius (Fig. 16.2) is an agnostoid, but its characters are inadequate for identification at lower taxonomic levels. The holotype was identified by Howell as a pygidium, but even that determination, in my opinion, is not entirely certain. The only previously illustrated paratype (Fig. 16.1) is a cephalon with characters similar to specimens of Hypagnostus, but Howell's handwritten label indicates that it is from a different locality than the holotype. Assignment of these two types to the same species cannot be verified, and the holotype lacks definitive characters. Therefore, I suggest that the name Cyclopagnostus hesperius be restricted to the holotype, and that Cyclopagnostus be regarded as an unrecognisable agnostoid genus.

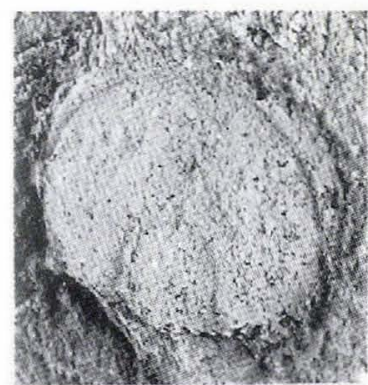

1

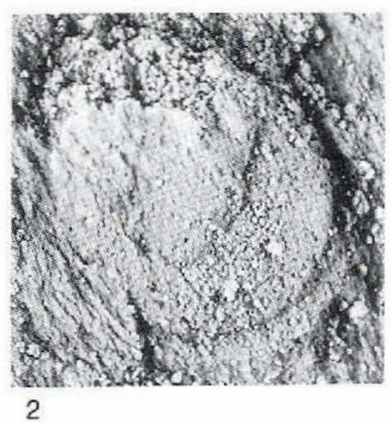

2
Fig. 16. Cyclopagnostus hesperius Howell from the St. Albans Shale of Vermont. 1, paratype cephalon, Princeton University no. 9797, $\times 8$. 2, latex cast of holotype, probably a pygidium, Princeton University no. 9796, $\times 8$.

Occurrence. H. brevifrons is cosmopolitan in open-marine lithofacies. Its observed stratigraphic range is from at least the middle Ptychagnostus punctuosus Zone to the middle Lejopyge laevigata Zone. All new specimens are from basal beds of the Kap Stanton Formation in Peary Land, and are from the lower $L$. laevigata Zone.

\section{Hypagnostus parvifrons (Linnarsson, 1869) Fig. 17}

New material. Three cephala and 4 pygidia are in GGU 298969, 319789, and 319790 .

Remarks. H. parvifrons is a common agnostoid species (e.g., Westergård, 1946, p. 45; Robison, 1964, p. 529; Öpik, 1979, pp. 66-67; Egorova et al., 1982, p. 69; Zhang \& Jell, 1987, p. 43-44; Sun, 1989, pp. 89-90; Samson et al., 1990, p. 1466) with cosmopolitan distribution in open-marine lithofacies. It is characterised by a glabellar length less than half that of the cephalon, an unfurrowed and moderately tumid pygidial axis, and a posteriorly widened pygidial border with a medial forward projection. The axis commonly extends to meet the medial projection of the border, but the two may connect by a short postaxial furrow. The new specimens from Greenland, like many from North America, have a shorter axis and a short postaxial median furrow.

Occurrence. The new specimens are from the upper Henson Gletscher Formation and the basal Kap Stanton Formation in Nyeboe Land, and they are from the Ptychagnostus atavus Zone and possibly basal $P$. punctuosus Zone. 


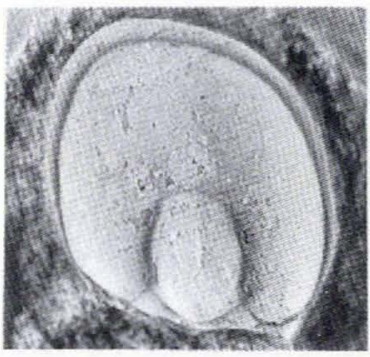

1

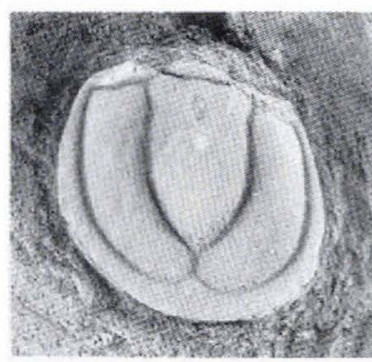

2
Fig. 17. Hypagnostus parvifrons (Linnarsson). 1, tectonically deformed cephalon, MGUH 21.385 from GGU 319789, × 8. 2 . pygidium, MGUH 21.386 from GGU $319790, \times 8$.

\section{Genus Peronopsis Hawle \& Corda, 1847}

Subjective junior synonyms include Mesagnostus Jaekel, 1909, Euagnostus Whitehouse, 1936, Eoagnostus Resser \& Howell, 1938, Archaeagnostus Kobayashi, 1939, Itagnostus Öpik, 1979, Svenax Öpik 1979, Axagnostus Laurie, 1990; questionable synonyms include Acadagnostus Kobayashi, 1939 and Micagnostus Khajrullina in Repina et al., 1975.

\section{Type species. Battus integer Beyrich, 1845, p. 44.}

Emended diagnosis. Genae anteriorly confluent. Glabella subcylindrical to slightly conical, rounded posteriorly, unequally divided by straight or nearly straight F3. Axial furrow may be incompletely effaced around anteroglabella. Basal lobes simple. Pygidium axiolobate and simplimarginate with ring furrows $(\mathrm{F} 1, \mathrm{~F} 2)$ variably developed. Posteroaxis ogival to lanceolate.

Remarks. More that a hundred species-group taxa having primitive agnostoid characters have been assigned to $P e$ ronopsis Hawle \& Corda, 1847, including some of the oldest known agnostoids of late Early Cambrian age. Some species are based on large populations of wellpreserved specimens that have been well documented. Many others, however, are based on one or a few specimens that commonly are incomplete, immature, poorly preserved, or otherwise inadequate for differential diagnosis. Since 1847, several Peronopsis-like genera have been proposed, but little attention has been given to phylogenetic relationships between them or to the taxonomic value of defining characters. In recent comments on the subject, Zhang \& Jell (1987, p. 45) concluded that "until these genera are interpreted on an international basis and their morphological features found to be consistent it serves no purpose to distribute one or two species among these very closely related and typologically erected genera." I concur in principle with that conclusion.

Many species that have been assigned to Peronopsis seem to represent a plexus of gradational lineages. During more than three decades of investigating such agnostoids, I have from time to time attempted to differentiate and define early peronopsid lineages as a prelude to possible application of either available or new generic names. From these investigations, I have been unable to identify characters, or sets of characters, with which I have confidence in their value for differentiation of phylogenetic lineages. Therefore, I continue the common practice of assigning agnostoid species with primitive characters to Peronopsis in the broad sense.

Peronopsis, as here diagnosed, includes the oldest known agnostoids. These are characterised by small lateholaspid size, commonly a bipartite glabella, simple basal lobes, confluent genae, narrow border furrows on the cephalon and pygidium, a short, broad, unfurrowed pygidial axis with weak median node, and lack of spines. Some early species (e.g., P. roddyi and its probable synonyms $P$. acrorhachis and $P$. primigenea; compare Rasetti \& Theokritoff, 1967, pp. 193-194, pl. 20, figs 1-22) show variable effacement of the axial furrow around the anteroglabella, and it is unclear whether this is a primitive or derived character. Such effacement also is variable in some later species (e.g., P. opimus Whitehouse; compare Robison in Jell \& Robison, 1978, pp. 9-10, pl. 2, figs 1-6), but it became complete and stable as a holaspid character in some clades that have been designated by generic names (e.g., Hypagnostus, Kormagnostus).

Among evolutionary trends demonstrated by some later species of Peronopsis are increase in maximum holaspid size, lengthening of the pygidial axis, variable development of ring furrows (F1, F2) on the pygidium, enlargement of the median node to a tubercle on the pygidial M2, widening of cephalic and pygidial border furrows, and appearance of a pair of spines on the posterior pygidial border. Weak genal scrobiculae rarely appeared during late generic phylogeny. Early species generally lack constriction of the pygidial axis, whereas most later species have a constricted M2 ring. With M2 constriction, the associated posteroaxis is commonly ogival, but may become lanceolate. Most of these characters also vary during ontogeny, and character transformations are interpreted to be heterochronic in origin. It is these collective factors that make taxonomic subdivision of Peronopsis difficult.

In comparing the type species of Peronopsis and Axagnostus (Peronopsis integra and Agnostus fallax, respectively), differential characters cited by Laurie (1990, p. 318 ) include shape of the anteroglabella, size of basal lobes, convexity of the pygidial border, constriction of 
the pygidial M2, length of the pygidial axis, and shape of the posteroaxis. In my opinion, the morphological differences between these two taxa are minor and are comparable to those commonly encountered between two species of the same agnostoid genus. At this time, I see little advantage in recognising two genera, and therefore consider Axagnostus to be a junior synonym of Peronopsis.

Peronopsis is cosmopolitan and eurytopic in marine lithofacies. It has an observed stratigraphic range from the upper Lower Cambrian to the upper Middle Cambrian.

\section{Peronopsis bulkurensis Pokrovskaya \&}

Pegel in Egorova et al., 1982

Fig. 18

Peronopsis bulkurensis Pokrovskaya \& Pegel in Egorova et al., 1982, p. 68 , pl. 56 , figs 11,12

New material. Six cephala and 7 pygidia are in GGU 298975.

Remarks. The cephalon of Peronopsis bulkurensis is not very distinctive. The late holaspid pygidium, however, is as much as $50 \%$ wider than long and is characterised by a swollen axis with a straight articulating furrow, weakly developed ring furrows, moderate-sized median tubercle, tumid posteroaxis, wide border furrow, and paired border spines of moderate size. During holaspid ontogeny, the pygidial axis anisometrically became wider, longer and more tumid, and the postaxial median furrow decreased in relative length and became less well defined.

Specimens of $P$. bulkurensis closely resemble those of P. lata Shabanov in Savitsky et al. (1972, p. 65, pl. 7, figs $13,14)$ and $P$. recta Pokrovskaya \& Egorova in Savitsky et al. (1972, pp. 65-66, pl. 7, figs 9, 10). Differences between these species appear to be more taphonomic than genetic, and the names may be synonyms. Further investigation of Siberian material is needed in order to test this possibility.

Pygidia of $P$. bulkurensis somewhat resemble those of P. fallax but the posteroaxis is more tumid, the ring furrows are better developed, the postaxial median furrow is not effaced on larger holaspides, and the posterior border is narrower and not as flat.

Occurrence. Peronopsis bulkurensis has been previously reported from Siberia in the upper part of the Ptychagnostus atavus Zone. The new specimens are from the upper Henson Gletscher Formation of Nyeboe Land, and are also from the Ptychagnostus atavus Zone.

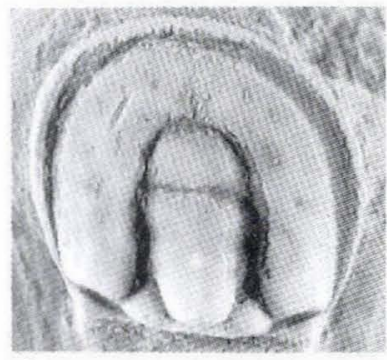

1

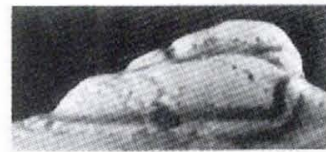

$2 b$

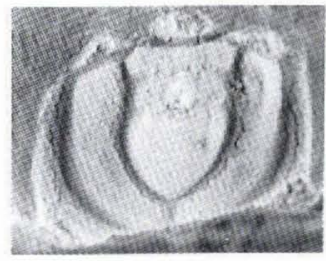

4

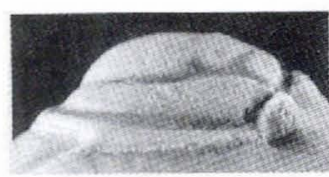

$5 a$

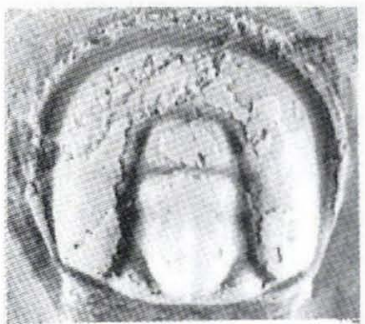

$2 a$
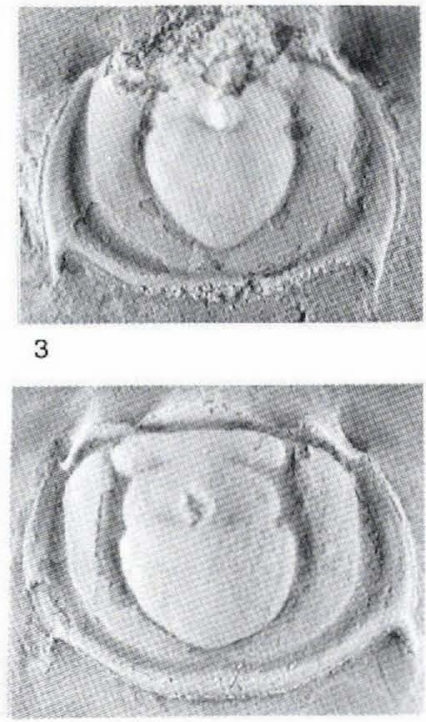

$5 b$
Fig. 18. Peronopsis bulkurensis Pokrovskaya \& Pegel. All specimens from GGU 298975. 1, cephalon with weak scrobicular pits on the genae and partly exfoliated furrows, MGUH 21.387, $\times 8.2 \mathrm{a}, \mathrm{b}$, partly exfoliated cephalon in dorsal and lateral views, MGUH 21.388, × 8. 3, 4, incomplete pygidia, MGUH 21.389 and 21.390 , both $\times 8$. 5, pygidium in lateral and dorsal views, MGUH 21.391, $\times 7$.

\section{Peronopsis fallax (Linnarsson, 1869)}

Fig. 19.3, 4

New material. Six pygidia are in GGU 319789 and 319790. Cephala of $P$. fallax are probably present in these collections, but I have been unable to identify them with confidence, partly because of poor preservation, and partly because closely similar cephala of other species of Peronopsis are present in the same collections.

Remarks. The taxonomy of $P$. fallax has been previously reviewed (Robison, 1982, pp. 152-156). In a subsequent study by Laurie (1990), fallax was reassigned as the type species of a new genus Axagnostus, and the concept of the species was significantly restricted. Upon further review of this species, I concede that inclusion of some 


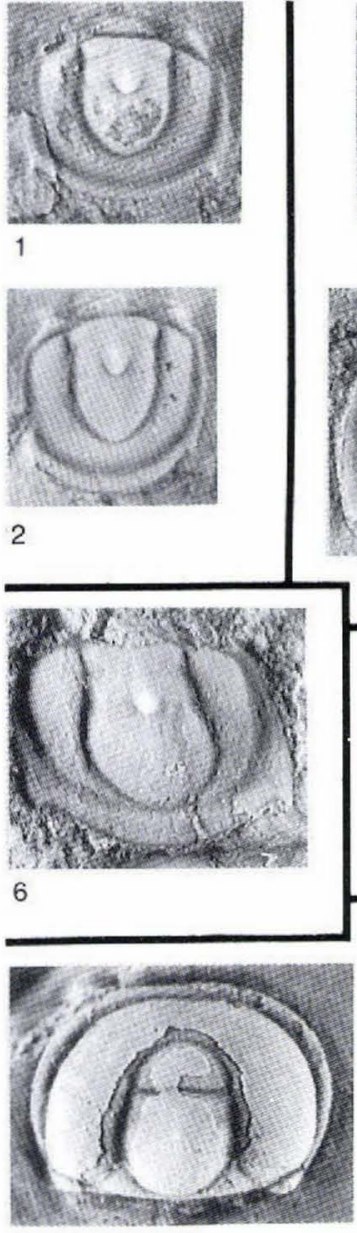

8

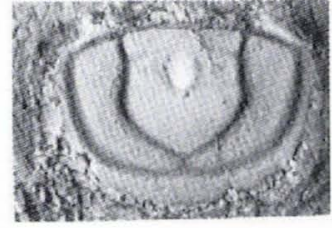

3

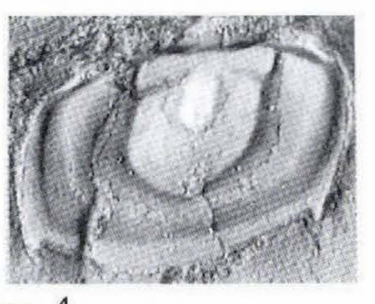

4

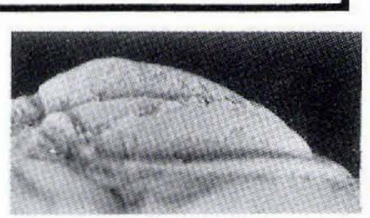

$7 a$

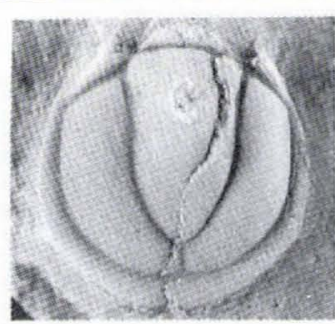

9

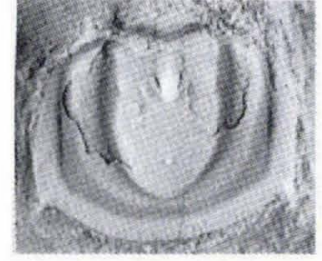

5

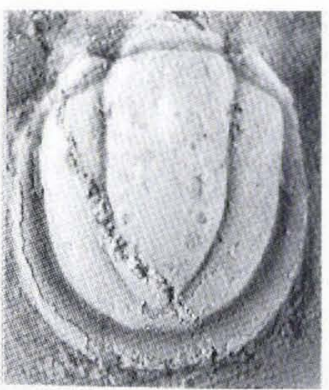

$7 \mathrm{~b}$

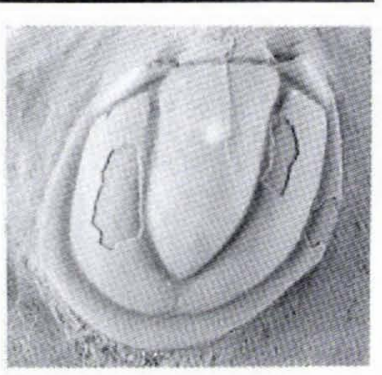

10

Fig. 19. Some species of Peronopsis. 1, 2, Peronopsis ferox (Tullberg); pygidia, MGUH 21.392 and 21.393 from GGU 298975, both $\times 10$.

3, 4, Peronopsis fallax (Linnarsson), both from GGU 319790. 3, pygidium, MGUH 21.394, × 10. 4, pygidium, MGUH $21.395, \times 7$.

5, Peronopsis sp. 3; pygidium, MGUH 21.396 from GGU 301313, $\times 10$.

6, Peronopsis sp. 2; latex cast of pygidium, MGUH 21.397 from GGU $319790, \times 8$.

7, Peronopsis sp. 1; lateral (a) and dorsal (b) views of pygidium, MGUH 21.398 from GGU 319789, $\times 8$.

8-10, Peronopsis interstricta (White) from GGU 319790. 8, cephalon, MGUH $21.399, \times 8.9,10$, pygidia, MGUH 21.400 and 21.401 . both $\times 6$.

specimens in my synonymy list of 1982 may warrant reconsideration, primarily because of their poor preservation or inadequate illustration. Nevertheless, my concept of fallax remains essentially unchanged, and is based on greater intrapopulation variability than seems to be accepted by Laurie.

Specimens of $P$. fallax are rare in the new collections and are not well preserved.

Occurrence. The new specimens are from basal beds of the Kap Stanton Formation in Nyeboe Land, and are from the upper Ptychagnostus atavus Zone.

\section{Peronopsis ferox (Tullberg, 1880)}

Fig. 19.1, 2

New material. Two small holaspid pygidia of $P$. ferox are in GGU 298975. Cephala of this species also may be present, but if so I have been unable to confidently differ- entiate them from cephala of other species of Peronopsis in the collection.

Remarks. Specimens of $P$. ferox are common at some localities in the western United States. A description of these and a taxonomic review of the species are being prepared for separate publication. The new pygidia are assigned to the species because of the short axis, effaced ring furrows, confluent pleural fields of uniform breadth, and pair of small marginal spines (compare Westergård, 1946, p. 38, pl. 2, fig. 27, pl. 3, fig. 2; Robison, 1972a, pp. 242-243, fig. 2A-F; Öpik, 1979, pp. 54-55, pl. 4, figs 4-7). They resemble pygidia of Agnostus lophotus n. sp., but differ by having a more straight articulating furrow and a posterior border that narrows toward the marginal spines.

Occurrence. P. ferox is rare in one collection from the upper Henson Gletscher Formation in Nyeboe Land, and the collection is from the Ptychagnostus atavus Zone. 
Peronopsis interstricta (White, 1874)

Fig. 19.8-10

Agnostus interstrictus White, 1874 , p. 7

Peronopsis interstricta (White), Robison, 1964, p. 530 (synonymy to date), pl. 81 , fig. 29 , pl. 82 , figs 1-15, 18; Robison, 1972a, pp. 244-245, fig. 4A-C; Gunther \& Gunther, 1981, pl. 44, fig. B; Robison, 1982, pp. 156-157, pl. 6, pp. 9-11; Young \& Ludvigsen, 1989, p. 11, pl. 1, figs 21-26, pl. 2, figs 1, 2; Robison, 1991, fig. 8.3

New material. More than 50 specimens, most tectonically deformed, are in GGU 319789 and 319790.

Remarks. The new specimens conform well with previous diagnoses (e.g., Robison, 1964, p. 530; Young \& Ludvigsen, 1989, p. 11).

Specimens of $P$. interstricta from North America and Greenland closely resemble those of $P$. opimus (Whitehouse, 1936) from Australia, differing mainly in less effacement of the axial furrow around the anteroglabella, slightly more posterior placement of the glabellar node, and a shorter pygidial axis (compare Robison in Jell \& Robison, 1978, p. 10). The chronostratigraphic range of $P$. interstricta encloses that of $P$. opimus, and it is possible that these minor differences may be phenotypic rather than genotypic. In the absence of a test for this hypothesis, however, I continue to recognise $P$. opimus as a separate species.

Occurrence. P. interstricta has been previously reported from the United States (Nevada, Utah) and Canada (western Newfoundland). In North Greenland, new specimens were collected from basal beds of the Kap Stanton Formation in Nyeboe Land. The composite observed species range is from the basal Ptychagnostus gibbus Zone into the Ptychagnostus punctuosus Zone. Associated agnostoids indicate that the Greenland specimens are from the upper Ptychagnostus atavus Zone.

\section{Peronopsis cf. pusilla (Tullberg, 1880)}

Fig. 20

Material. About 25 specimens are in GGU 298974, 298975 , and 319790 .

Remarks. Several specimens of Peronopsis from North Greenland closely resemble Swedish representatives of $P$. pusilla (e.g. Westergård, 1946, pp. 42-43, pl. 4, figs 12-18), a species characterised by weak genal scrobiculae, low relief of the anteroglabella, a short pygidial axis with effaced ring furrows, and a longer than usual postaxial median furrow. The new specimens differ, however, in having smooth genae, greater relief of the anteroglabella, and wider cephalic and pygidial borders. Although minor, these differences are stable in the small samples from North Greenland. Whether these are phenotypic or genotypic differences is an open question, and I therefore leave open the species assignment of these specimens.

Some of the specimens from Greenland are larger than any previously illustrated for $P$. pusilla. The entire population demonstrates ontogenetic elongation of the pygidial axis, correlative shortening and final effacement of the postaxial median furrow, and incipient development of a transverse sulcus on the posteroaxis (Fig. 20.4). In outline, the pygidium also grades from subcircular in small holaspides to subquadrate in large holaspides. The largest pygidium (Fig. 20.4) has fine radial ridges on the pleural fields.

Öpik (1979, pp. 64 65) reassigned $P$. pusilla as the type species of a new genus Svenax. For reasons stated in the remarks on Peronopsis, I consider Svenax to be a junior synonym.

Occurrence. Specimens are common in two collections

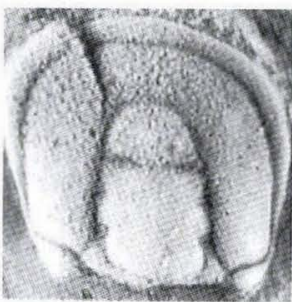

$1 \mathrm{a}$

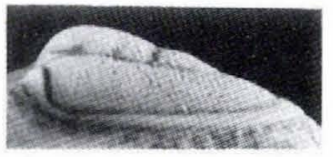

$1 \mathrm{~b}$

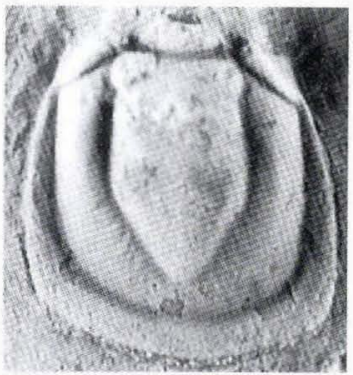

$4 a$

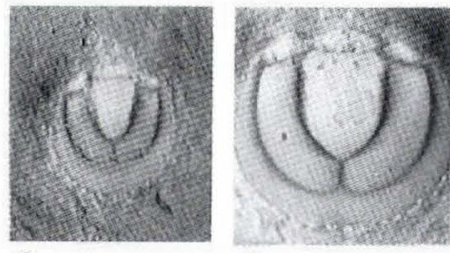

3
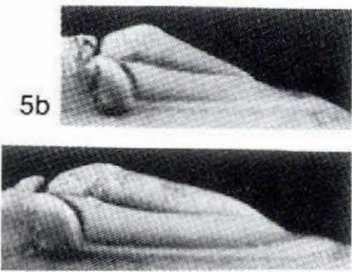

$4 b$

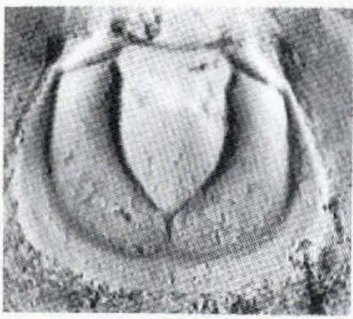

$5 a$
Fig. 20. Peronopsis cf. pusilla (Tullberg). All specimens from GGU 298975. 1a, b, cephalon in dorsal and lateral views, MGUH $21.402, \times 7.2,3$, smaller holaspid pygidia, MGUH 21.403 and 21.404 , both $\times 10.4,5$, larger holaspid pygidia in dorsal (a) and lateral (b) views, MGUH 21.405 and 21.406, both $\times 8$. 


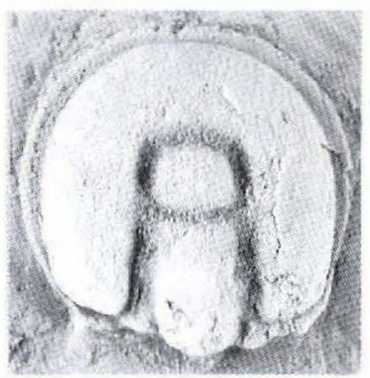

2

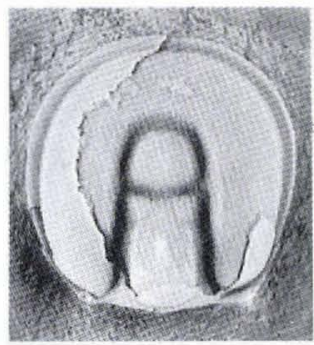

$4 a$

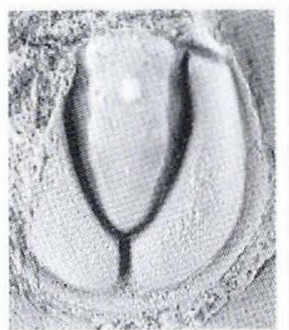

$7 a$

$7 \mathrm{~b}$

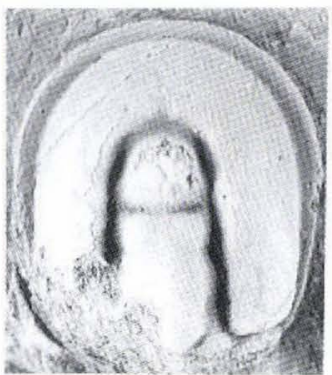

$3 a$

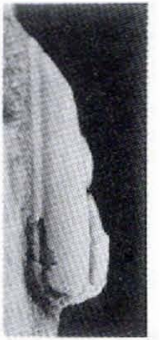

$4 b$

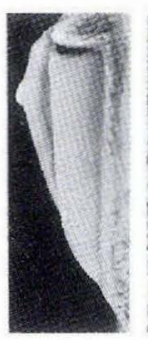

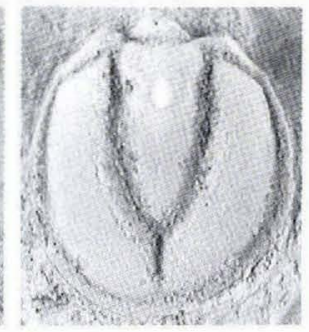

$8 a$

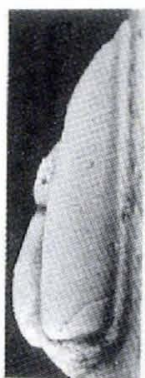

3b

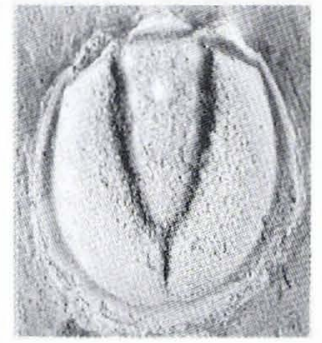

6

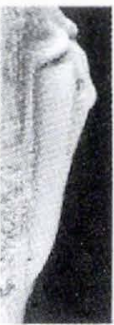

$8 b$

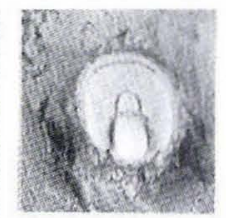

1

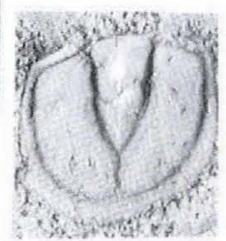

5

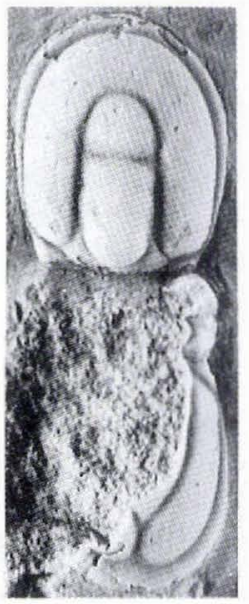

9

Fig. 21. Peronopsis scutalis (Hicks). 1, small holaspid cephalon, MGUH 21.407 from GGU 298969, × 10. 2, mostly exfoliated, large holaspid cephalon, MGUH 21.408 from GGU $298969, \times 5.3 \mathrm{a}, \mathrm{b}$, dorsal and lateral views of partly exfoliated cephalon showing posterior development of incipient preglabellar median furrow, MGUH 21.409 from GGU $298970, \times 5.4 a, b$, dorsal and lateral views of partly exfoliated cephalon having finely punctate genae, MGUH 21.410 from GGU 298969, $\times 5.5$, small holaspid pygidium, MGUH 21.411 from GGU 298969, $\times 8$. 6, exfoliated pygidium, MGUH 21.412 from $298969, \times 5.7 a, b$, exfoliated, incomplete pygidium in dorsal and lateral views, MGUH 21.413 from GGU 298970, × 5. 8a, $\mathrm{b}$, exfoliated pygidium in dorsal and lateral views, MGUH 21.414 from GGU 298969, × 5. 9, mostly testate but incomplete exoskeleton, MGUH 21.415 from GGU 310790, × 6 .

from the upper Henson Gletscher Formation and one pygidium is in a collection from the basal Kap Stanton Formation, all from Nyeboe Land. All three collections are from the Ptychagnostus atavus Zone. For comparison, Peronopsis pusilla has been previously reported from Sweden, Norway, Denmark, and Australia where it has a composite observed stratigraphic range from the $P$. atavus Zone to the P. punctuosus Zone (Westergaird, 1946, p. 43, Öpik, 1979, pp. 64-65). Howell (1925, pp. 37-38) also reported Peronopsis cf. pusilla and Ptychagnostus punctuosus in a faunal list for eastern Newfoundland, Canada.

\section{Peronopsis scutalis (Hicks, 1872)}

Fig. 21

New material. More than 100 specimens are in GGU 298969, 298970, 319789, and 319790.

Emended diagnosis. Peronopsis having narrow border furrows, moderately deep to deep axial furrow, and no border spines. Cephalon subcircular to subquadrate. Gla- bella slightly tapering toward anterior, length approximately two-thirds that of cephalon, F3 well defined; anteroglabella slightly wider than long, broadly rounded anteriorly; posteroglabella with median node near midlength. Pygidium subcircular to ovoid. Axis variable in length, with posterior end depressed; F1 and F2 mostly or entirely effaced; median tubercle on M2 small but prominent; posteroaxis lanceolate with secondary median node at about midlength. Postaxial median furrow deep.

Remarks. Peronopsis scutalis is used here in the broad sense of Westergård (1946, pp. 41-42) and Rushton (1979, pp. 50-51). The name is applied to a common group of Peronopsis in which length and terminal shape of the pygidial axis is variable. Several authors, including myself (Robison, 1988, p. 48), have attempted to taxonomically differentiate this group. After further study, partly based on new material, I now conclude that published information is an inadequate basis for meaningful taxonomic subdivision of the group. Further progress will probably require detailed analysis of type material of several taxa, most of which is not available to me at this 
time. Smaller holaspides from Greenland closely resemble the lectotype of Agnostus exaratus tenuis Illing, 1916, which was reillustrated as Peronopsis scutalis tenuis by Rushton (1979, fig. 3G).

Westergård (1946, p. 41) mentioned that most cephala and pygidia of $P$. scutalis in collections from Sweden are between 2 and $3 \mathrm{~mm}$ long, and shields 5 to $6 \mathrm{~mm}$ long are rare. In comparison, cephala and pygidia 5 to $6 \mathrm{~mm}$ long are common in new GGU collections from Greenland. These larger specimens usually have much deeper and stronger axial and postaxial median furrows than do smaller holaspides, especially those with a cephalon or pygidium less than about $3 \mathrm{~mm}$ long. Some accentuation of dorsal furrows on the larger holaspides, however, may be related to taphonomic compression in an argillaceous matrix. During holaspid ontogeny of Greenland specimens the posterior end of the pygidial axis changed from acutely pointed (Fig. 21.5) to sharply rounded (Fig. 21.7a). Larger holaspides also may have a shallow transverse sulcus on the posteroaxis.

Specimens that I previously assigned to Peronopsis tenuis (Robison, 1988, pp. 47-48, fig. 10.7, 8, 10-12)) are here reassigned to $P$. scutalis in the broad sense. Those preserved in grainstone have a secondary median node near the posterior end of the axis (Robison, 1988, fig. $10.10,11$ ), whereas new specimens preserved in argillaceous mudstone have a secondary node further forward on the axis (Fig. 21.7a). Whether or not these nodes are homologous and whether or not their positions are genotypically or phenotypically controlled are all unknown. Therefore, the position of such nodes is not here accorded taxonomic value.

Occurrence. Peronopsis scutalis is widespread in openmarine lithofacies that mostly seem to represent coolwater environments. It has a composite observed stratigraphic range from the Ptychagnostus gibbus to the Lejopyge laevigata zones. The new specimens are from the upper Henson Gletscher Formation and the basal Kap Stanton Formation, both in Nyeboe Land, and these specimens have an observed range from the $P$. gibbus Zone to the upper Ptychagnostus atavus Zone.

\section{Peronopsis sp. 1}

Fig. 19.7

Remarks. A single pygidium in GGU 319789 lacks spines and is characterised by an unusually long posteroaxis. It closely resembles a pygidium from the Lejopyge laevigata Zone of Sweden that Westergård (1946, p. 43, pl. 3, fig. 16) illustrated as Peronopsis ef. insignis (Wallerius), but differs by having a more elongate and less distinct axial node, a less angular lateral profile, and by lacking paired muscle scars. The new specimen is from basal beds of the Kap Stanton Formation of Nyeboe Land, and is from the upper Ptychagnostus atavus Zone.

\section{Peronopsis sp. 2}

Fig. 19.6

Remarks. A single undetermined pygidium of Peronopsis is in GGU 319790 from the upper Ptychagnostus atavus Zone in basal beds of the Kap Stanton Formation, Nyeboe Land. Its lateral margins diverge slightly toward the posterior and it has a long axis that extends to the posterior border. Ring furrows are nearly effaced and the median node is strong and elongate. The posteroaxis is laterally expanded and has a broadly angular posterior margin. The border furrow is moderately wide, the posterior border is medially expanded, and a pair of border spines are of moderate size. The taxonomic affinities of this specimen within Peronopsis are unclear. It superficially resembles the pygidium of Iniospheniscus incanus Öpik, but its axis is narrower, its lateral margins diverge rather than converge toward the posterior, and its border spines are larger.

\section{Peronopsis sp. 3}

Fig. 19.5

Remarks. A small, single, undetermined pygidium of Peronopsis is in GGU 301313 from the Lejopyge laevigata Zone in basal beds of the Kap Stanton Formation, Peary Land. It is characterised by an elongate, subcylindrical axis that extends almost to the posterior border furrow. The median node is carinate, ring furrows are very weak on the exfoliated surface, and a secondary median node is on a long posteroaxis about one-third of its length from the back margin. The border furrow is wide, the lateral and posterior borders are subequal in width except anterolaterally where they narrow, pleural fields are narrow but confluent behind the axis, and two border spines are small. This pygidium resembles that of smaller holaspides of Peronopsis bulkurensis, but it has a longer axis, lacks a postaxial median furrow, and has a secondary median node. It also resembles the pygidium of Peronopsis sp. 2 but its posteroaxis is not laterally swollen and its exterior border is more uniform in width.

\section{Family Ptychagnostidae Kobayashi, 1939}

Remarks. The family diagnosis of Robison (1984) is followed here. Further phylogenetic analysis during this study, in part based on new material, has identified two ptychagnostid lineages showing parallel evolution. Each 
lineage commenced with a furrowed species and each evolved highly effaced, homeomorphic species. The available names Lejopyge Hawle \& Corda, 1847 and Pseudophalacroma Pokrovskaya, 1958 are here applied to these lineages. The diagnosis of each genus is emended accordingly (see below).

In previous discussion of Lejopyge, Öpik (1979, pp. 158-159) concluded that a high degree of effacement evolved twice in separate lineages within the genus, and that one lineage maintained its continuity in the species of Pseudophalacroma. Although the two lineages discussed by Öpik share some species with the two lineages identified here, our conclusions differ significantly on the source of each lineage and its species content (see remarks below on Lejopyge and Pseudophalacroma).

The Ptychagnostidae, after generic emendations that follow, includes Ptychagnostus, Goniagnostus, Lejopyge, Myrmecomimus, Pseudophalacroma and Tomagnostus. Tomagnostella is questionably assigned to the family.

\section{Genus Lejopyge Hawle \& Corda, 1847}

Lejopyge Hawle \& Corda, 1847, p. 51; Kobayashi, 1937, pp. 437-447; Kobayashi, 1939, pp. 131-132; Lermontova, 1940, p. 130; Westergård, 1946, p. 87; Pokrovskaya, 1958, pp. 72-76; Howell in Harrington et al., 1959, p. 178; Pokrovskaya in Chernysheva, 1960, p. 60; Öpik, 1961, p. 85; Robison, 1964, p. 521; Palmer, 1968, p. 27; Daily \& Jago, 1975, pp. 527-550; Jago, 1976, p. 12; Öpik, 1979, pp. 157-159; Robison, 1984, pp. 36-37; Robison, 1988, p. 48; Laurie, 1989, pp. 186-188; Shergold et al, 1990, p. 40

Miagnostus Jaekel, 1909, p. 401

Onymagnostus Öpik, 1979, pp. 107-108; Robison, 1984, pp. 50-51; Laurie, 1988, p. 187; Shergold et al., 1990, p. 41

Onymagnostus (Agnostonymus) Öpik, 1979, p. 114

Type species. Battus laevigatus Dalman, 1828, pp. 136137.

Emended diagnosis. Ptychagnostidae with furrows on acrolobes well developed to mostly effaced. Glabella elongate, slightly and irregularly tapered, rounded to bluntly pointed anteriorly. Basal lobes slightly elongate to simple. Cephalic border of variable width in furrowed species, becoming very narrow in highly effaced species. Genae smooth to weakly scrobiculate. Pygidial axis long to moderately long; M2 hexagonal; posteroaxis commonly ogival on furrowed species, becoming almost lanceolate with near effacement of axial furrow. Postaxial median furrow becoming effaced and pygidial pleurae becoming confluent during ontogeny, usually by early stages of holaspid period. Pygidial border fairly uniform in width laterally and posteriorly, narrowing at anterolateral corners; moderately wide in furrowed species, be- coming narrow in effaced species. Spine development variable and iterative on posterior cephalic border, thorax, and posterior pygidial border.

Remarks. After further phylogenetic analysis, the concept of Lejopyge Hawle \& Corda, 1847 is here emended from previous discussion (Robison, 1984, pp. 36-37). It also is broadened to include species that have not been previously assigned to the genus, and the generic synonymy is significantly modified.

Prior to 1979 , authors assigned to Lejopyge only species having advanced effacement of furrows on the acrolobes. In his monograph on Swedish agnostoids, Westergård (1946, p. 87) summarised the taxonomic history of Lejopyge, and concluded (p. 75) that "Ptychagnostus (Tr.) elegans, elegans laevissimus, and Lejopyge laevigata constitute an evolutional series with very small intervals." In 1979, Öpik (p. 158) noted his acceptance of Westergård's phyletic concept, but assigned all three of the taxa cited by Westergård to Lejopyge. To the beginning of the phyletic series, and to the genus Lejopyge, he also reassigned Agnostus lundgreni Tullberg, 1880 and $A$. lundgreni var. nana Grönwall, 1902, which are furrowed taxa. Following Öpik, I (Robison, 1984, p. 37) accepted lundgreni as the ancestral species of Lejopyge, and further suggested (p. 46) that L. lundgreni probably originated from a lineage containing Ptychagnostus intermedius. Laurie (1989, p. 176) also included lundgreni in Lejopyge, but re-evaluated some morphology to support an alternative suggestion "that an origin for Lejopyge lies somewhere within Onymagnostus."

As a test of the phylogeny suggested by Laurie, I have analysed the characters of several species of Lejopyge and Onymagnostus using PAUP (Swofford, 1990). Ptychagnostus praecurrens was selected as the outgroup because it is the oldest known species of the Ptychagnostidae (Robison, 1978, p. 2) and it has character states that are inferred to be primitive for the family. It was found that most species of Lejopyge cluster closely with those of Onymagnostus, but they do not cluster closely with lundgreni, which supports Laurie's suggestion regarding the source of Lejopyge. Further phylogenetic analysis of species (Fig. 22 and Table 2), based in part on new and well-preserved specimens from North Greenland, has indicated that Agnostus barrandei Hicks, 1872 and Agnostus elegans Tullberg, 1880 fill intermediate positions in a multi-character morphological gradient leading from $\mathrm{Ag}$ nostus hybridus Brøgger, 1878, the type species of Onymagnostus, to Battus laevigata Dalman, 1828, the type species of Lejopyge. In an exhaustive search in which all characters were equally weighted, five parsimony trees were discovered. The majority-rule consensus tree (Fig. 22) has the same arrangement of species as one of the 
Fig. 22. Majority-rule consensus tree for species of Lejopyge constructed from character data in Table 2. The outgroup is Ptychagnostus praecurrens.

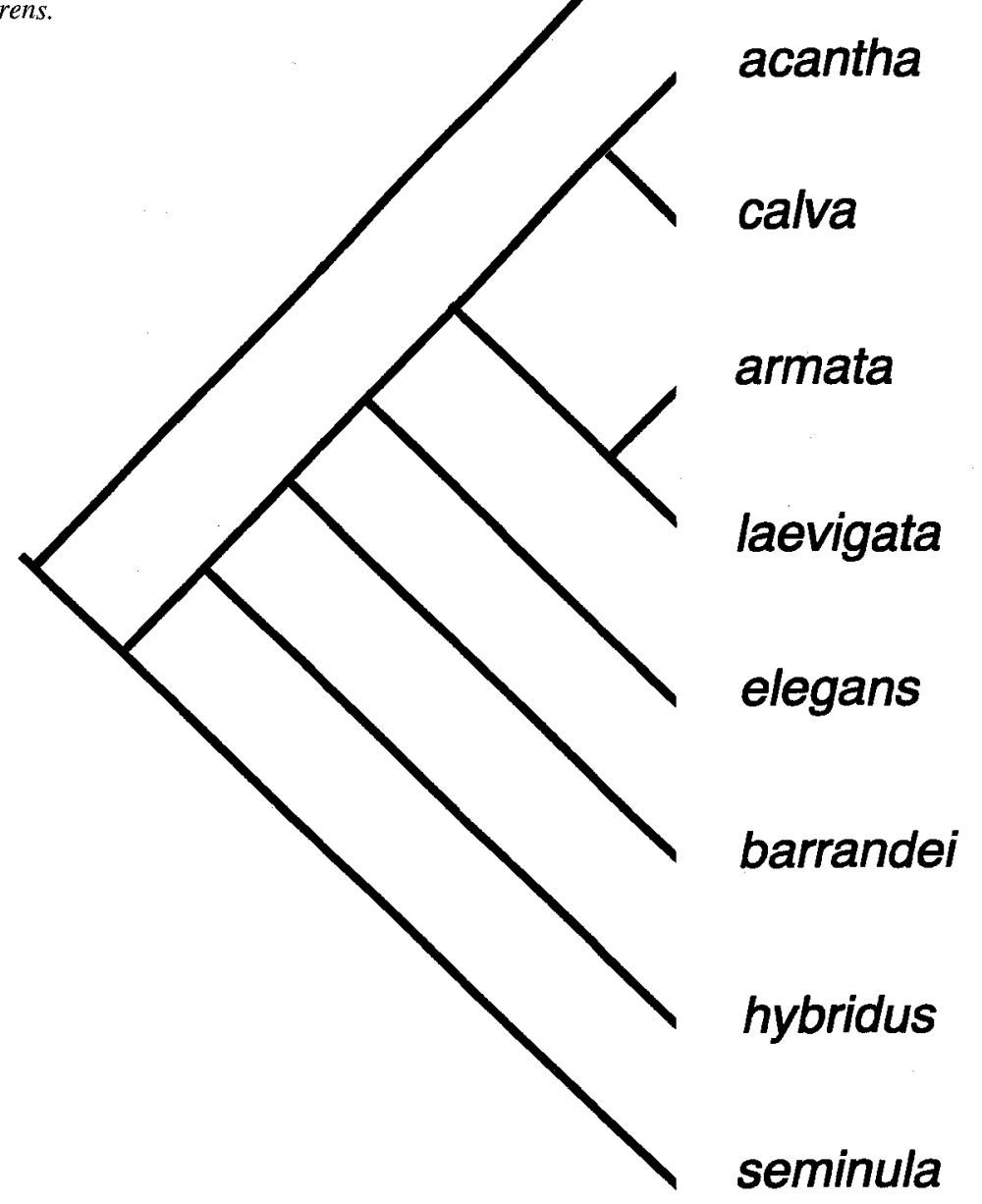

parsimony trees. The morphological changes between each of the analysed species are judged to be taxonomically trivial. Also, it is clear from Fig. 22 that Onymagnostus, as recognised by previous authors, is paraphyletic. For these reasons, I now propose the suppression of Onymagnostus as a subjective junior synonym of Lejopyge.

As emended, Lejopyge includes L. laevigata (Dalman, 1828), L. armata (Linnarsson, 1869), L. barrandei (Hicks, 1872), L. hybridus (Brøgger, 1878), L. elegans (Tullberg, 1880), L. seminula (Whitehouse, 1939), L. calva Robison, 1964, and L. acantha Robison 1984. The inferred phylogenetic relationship of these species is shown by Fig. 22. With further evaluation, other previously named species may also warrant assignment to Lejopyge.

The described morphological differences between $L$. seminula and Onymagnostus semiermis Öpik, 1979 are praecurrens

acantha

calva

armata

laevigata

elegans

seminula

comparable to the variation observed within large populations of $L$. hybridus, and I therefore further propose the suppression of semiermis as a subjective junior synonym of $L$. seminula. The geographic source and age of the holotype of $L$. seminula are questionable (Robison, 1982, pp. 148-150).

Some species that were previously assigned to Lejopyge, including $A$. lundgreni and Lejopyge rigbyi Robison, 1984, are here reassigned to Pseudophalacroma (see below).

Lejopyge, as emended, is interpreted to be a monophyletic (holophyletic) genus that commences with $L$. seminula, an inferred descendent of Ptychagnostus praecurrens. Some species of Lejopyge retain a primitive furrowed condition and others show variable effacement of acrolobe features. Furrowed species are characterised by an elongate axial lobe. The glabella has a minor and irregular taper. A median node is anterior from the mid- 


\section{Table 2. Characters, character states and data matrix for Ptychagnostus praecurrens and Lejopyge used to construct the cladogram}

Late holaspid characters, character states, and data matrix for Ptychagnostus praecurrens and eight species of Lejopyge, which were used to construct the cladogram in Fig. 22. Characters not preceded by an asterisk and scored ' 0 ' represent the ancestral state, and the same characters scored ' 1 ,' ' 2 ,' ' 3 ,' or ' 4 ' represent derived states coded as additive transformations. For characters preceded by an asterisk $(*)$, the character states are unordered. A question mark (?) indicates missing data. If multistate characters are present in a species, the most common state is scored in the data matrix.

*1. Cephalic border spines: absent (0) or present (1).

2. Preglabellar median furrow: present (0) or effaced (1).

*3. Axial furrow of cephalon: fully developed (0), uniformly weak (1), effaced anterior of F3 (2), effaced anterior of F2 (3), or effaced anterior of basal lobes (4).

*4. Basal lobes: slightly elongate $(0)$, simple (1), or elongate (2).

5. Cephalic F3: fully developed (0), weak (1), or effaced (2)

*6. Median node of posteroglabella: behind midpoint $(0)$, at midpoint (1), or in front of midpoint (2).

*7. Pygidial border spines: absent (0), incipient (1), or fully developed (2).

8. Postaxial median furrow: present (0) or effaced (1).

*9. Separation of pygidial axis and posterior border furrow: moderate $(0)$, narrow (1), or wide (2).

$* 10$. Axial furrow of pygidium: fully developed (0), weak (1), effaced behind F2 (2), or effaced behind F1 (3).

11. Pygidial F1: fully developed (0), weak (1), or effaced (2).

12. Pygidial F2: fully developed (0), weak (1), or effaced (2).

*13. Pygidial M2 with median: node (0), tubercle (1), or spine (2).

14. Posteroaxis: ogival (0) or lanceolate (1).

Species

Character

$\begin{array}{llllllllllllll}1 & 2 & 3 & 4 & 5 & 6 & 7 & 8 & 9 & 10 & 11 & 12 & 13 & 14\end{array}$

$\begin{array}{lllllllllllllll}P \text { p praecurrens } & 0 & 0 & 0 & 0 & 0 & 0 & 0 & 0 & 0 & 0 & 0 & 0 & 0 & 0\end{array}$

$\begin{array}{lllllllllllllll}\text { L. acantha } & 1 & 1 & 4 & 1 & 2 & \text { ? } & 0 & 1 & \text { ? } & 3 & 2 & 2 & 0 & \text { ? }\end{array}$

$\begin{array}{lllllllllllllll}\text { L. armata } & 1 & 1 & 3 & 1 & 2 & 0 & 2 & 1 & 0 & 2 & 2 & 2 & 0 & \text { ? }\end{array}$

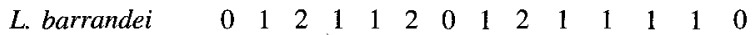

$\begin{array}{llllllllllllllll}\text { L. calva } & 0 & 1 & 4 & 1 & 2 & \text { ? } & 0 & 1 & \text { ? } & 3 & 2 & 2 & 0 & \text { ? }\end{array}$

$\begin{array}{lllllllllllllll}\text { L. elegans } & 0 & 1 & 1 & 1 & 1 & 1 & 0 & 1 & 0 & 1 & 1 & 1 & 0 & 1\end{array}$

$\begin{array}{lllllllllllllll}\text { L. hybridus } & 0 & 0 & 0 & 1 & 0 & 2 & 0 & 1 & 0 & 0 & 0 & 0 & 1 & 0\end{array}$

$\begin{array}{lllllllllllllll}\text { L. laevigata } & 0 & 1 & 3 & 1 & 2 & 0 & 0 & 1 & \text { ? } & 2 & 2 & 2 & 0 & \text { ? }\end{array}$

$\begin{array}{lllllllllllllll}\text { L. seminula } & 0 & 0 & 0 & 0 & 0 & 2 & 1 & 1 & 1 & 0 & 0 & 0 & 1 & 0\end{array}$

point of the posteroglabella in furrowed species, but its more posterior position in some effaced species suggests either migration of a single node during phylogeny or possible suppression of the original node and development of a latent, more posterior node (compare Robison, 1984 , p. 17). Basal lobes are slightly elongate in $L$. seminula, the earliest species of Lejopyge, but are mostly simple in later species of the genus. Width of the cephalic border is fairly uniform within species, but varies during phylogeny, ranging from moderate in furrowed species to very narrow in some effaced species. The pygidial axis is ogival in species with a well-developed axial furrow, but approaches a lanceolate condition with near effacement of that furrow in L. elegans (e.g., Westergård, 1946, pl. 10 , figs 14,19$)$. It is also important to note that taphonomic compression and deformation of furrowed specimens in argillaceous matrix has commonly resulted in deepening of some furrows (especially the axial furrow), narrowing of the axial lobe, and deformation of the axial tip to a pointed, pseudolanceolate condition. On the pygidial axis of furrowed species the second ring is characteristically hexagonal and has a large posteromedian tubercle that deeply embays the second ring furrow (F2). With intermediate effacement of the acrolobe, as in L. barrandei, a smaller node may be superimposed on the median tubercle (see Fig. 23.3), or the F2 and the primary tubercle may disappear, leaving only the smaller secondary node (see Fig. 23.8). Width of the pygidial border is usually moderate and fairly uniform, but may narrow slightly in species with advanced effacement of the acrolobe.

Lejopyge and Pseudophalacroma, as emended, have overlapping geographic and stratigraphic ranges. Early, furrowed species of Lejopyge clearly differ from early, furrowed species of Pseudophalacroma by having a longer axial lobe, a less tapered glabella, a median node that is anterior rather than posterior from the midpoint of the posteroglabella, a larger tubercle on the pygidial M2, usually no postaxial median furrow on late holaspides, and a pygidial border of more uniform width. Advanced effacement of the acrolobes in late species of both Lejopyge and Pseudophalacroma makes generic identification difficult. Nevertheless, late species of Lejopyge differ from late species of Pseudophalacroma by having a pygidial border that is sagittally narrower and which remains more uniform in width.

Some partially effaced agnostoids closely similar to Lejopyge barrandei have been assigned to Cotalagnostus. Review of literature on Cotalagnostus, as well as some type material, suggests that polyphyletic species have been assigned to the genus. It also appears likely that the only two illustrated syntypes of the type species, Agnostus lens Grönwall, 1902, represent two species. Therefore, to stabilise nomenclature and taxonomic concepts, I here select the illustrated syntype pygidium (Grönwall, 1902, pl. 1, fig. 9) to be the lectotype of $A$. lens. That lectotype appears to represent a peronopsid, whereas the illustrated syntype cephalon, except for size, is virtually indistinguishable from the only illustrated syntype cephalon of Agnostus altus Grönwall (1902, pl. 
1, fig. 3), which is here considered to be a junior synonym of Lejopyge barrandei.

Lejopyge, as emended, is widely distributed in openmarine lithofacies and has an observed stratigraphic range from the lower Ptychagnostus gibbus Zone to at least the top of the L. laevigata Zone.

Without an opportunity to observe type material of Phoidagnostus Whitehouse, 1936, I (Robison, 1984, pp. 36-37) previously accepted Öpik's (1961, pp. 54, 86; 1967, p. 76) conclusion that Phoidagnostus is a synonym of Lejopyge. After re-examination of the holotype of $P$. limbatus, the type species of Phoidagnostus, Laurie (1989, pp. 187-188) concluded that Phoidagnostus is not a synonym of Lejopyge. Subsequently, Shergold et al. (1990, p. 56, fig. 18.5) gave a diagnosis of Phoidagnostus, assigning it under 'Familae Incertae Sedis,' and they published the first photograph clearly illustrating the holotype of $P$. limbatus. That holotype is a cephalon and incomplete thorax of an effaced agnostoid that appears to be taphonomically deformed. In my opinion, its poor preservation and lack of diagnostic characters preclude adequate comparison with other effaced agnostoid taxa. Therefore, I now consider Phoidagnostus to be an unrecognisable genus.
Fig. 23. Lejopyge barrandei (Hicks). All specimens preserved with original convexity in calcareous matrix of GGU 298970, unless stated otherwise. 1a, b, large, mostly exfoliated cephalon in dorsal and lateral views, MGUH 21.416, × 5. 2, cephalon, MGUH 21.417, × 6. 3, pygidium, MGUH 21.418, × 8. 4, 6, cephala partially flattened in argillaceous matrix, MGUH 21.419 and 21.420 from GGU $298969, \times 8$ and $\times 6.5$, cephalon, MGUH 21.421, $\times$ 8.7, pygidium, MGUH 21.422, × 6.8, partly exfoliated pygidium having densely spaced, fine punctae in test, MGUH 21.423, × 6. 9, pygidium flattened in argillaceous matrix, MGUH 21.424 from GGU 298969, $\times 6.10 \mathrm{a}, \mathrm{b}$, large, partly exfoliated pygidium in dorsal and lateral views, MGUH 21.425, x 5. 11a, b, pygidium, slightly flattened in argillaceous matrix, in lateral and dorsal views, MGUH 21.426 from GGU $298969, \times 8$.

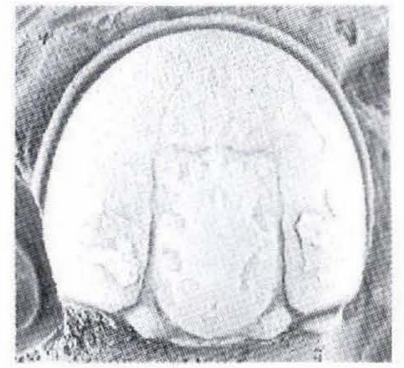

$1 \mathrm{a}$

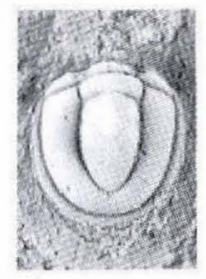

3

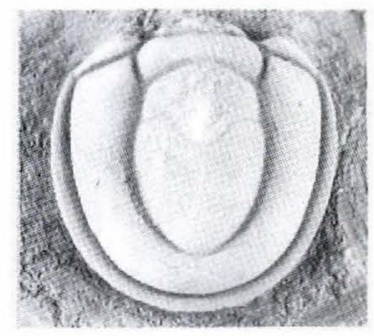

7

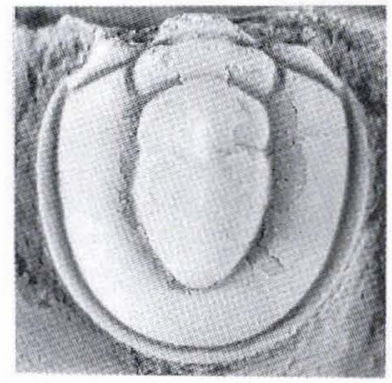

$10 a$

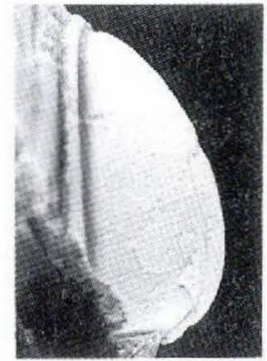

$1 \mathrm{~b}$

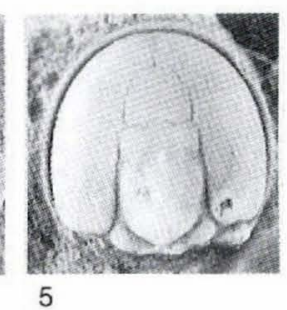

5

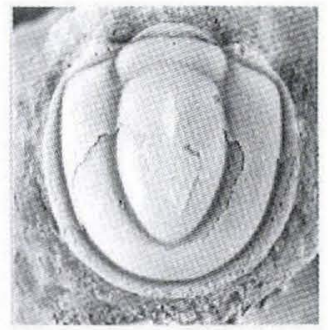

8

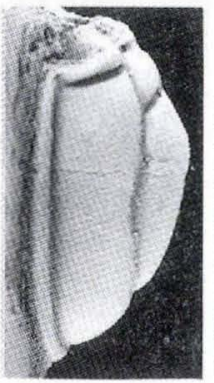

$10 \mathrm{~b}$

$11 \mathrm{a}$

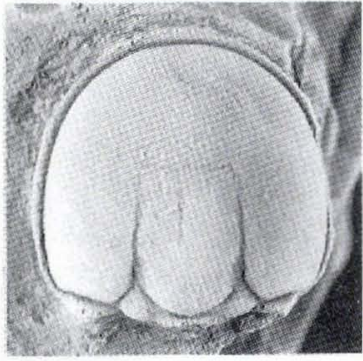

2

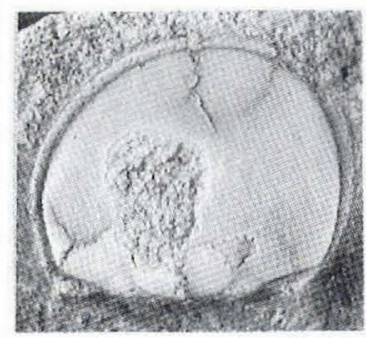

6

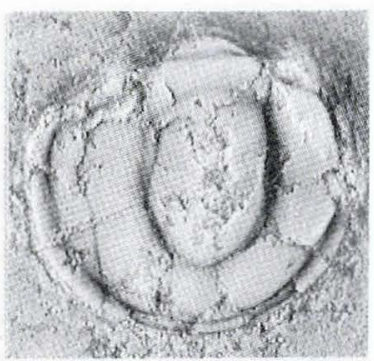

9

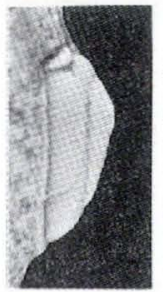

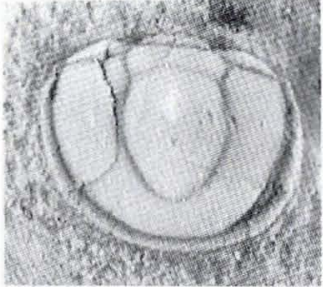

$11 b$ 
Lejopyge barrandei (Hicks, 1872)

Fig. 23

Agnostus barrandei Hicks, 1872, p. 176, pl. 5, figs 5, 6; Lake, 1906 , p. 13, pl. 2, fig. 2; Illing, 1916, p. 413, pl. 30, figs 13, 14; Lake, 1946, p. 338

Agnostus laevigatus var. terranovicus Matthew, 1896, pp. 233234 , pl. 17, figs $1 \mathrm{a}, 1 \mathrm{~b}$

Agnostus laevigatus var. ciceroides Matthew, 1896, p. 234, pl. 17 , figs $3 \mathrm{a}, 3 \mathrm{~b}$

?Agnostus laevigatus var. mammilla Matthew, 1896 (in part), p. 234, pl. 17, fig. 2a (not 2b) [see Hutchinson, 1962, p. 86]

Agnostus altus Grönwall, 1902, pp. 58-59, pl. 1, figs 3, 4; Lake, 1906, pp. 12-13, pl. 2, fig. 1; Illing, 1916, p. 412, pl. 30, figs 9,10

?Agnostus lens Grönwall, 1902 (in part), pp. 65-66, pl. 1, fig. 8 (not 9)

Cotalagnostus altus (Grönwall), Whitehouse, 1936, p. 93; Kobayashi, 1939, p. 129; Pokrovskaya in Chernysheva, 1960, pl. 1, fig. 30

Cotalagnostus barrandei (Hicks), Whitehouse, 1936, p. 93; Kobayashi, 1939, p. 129

Cotalagnostus illingi Kobayashi, 1939, p. 129

Cotalagnostus ciceroides (Matthew), Kobayashi, 1939, p. 129

Cotalagnostus mammillata (Matthew), Kobayashi, 1939, p. 129

Cotalagnostus terranovicus (Matthew), Kobayashi, 1939, p. 129

Ptychagnostus convexus Westergård, 1946, pp. 73-74, pl. 10, figs $5-10$

Ptychagnostus ciceroides (Matthew), Hutchinson, 1962 (in part); 85-86, pl. 9, figs 20-22 (?not 23), pl. 10, figs 2-8 (?not 1); Poulsen, 1969, pp. 5-6, fig. 5a, ?5b

Ptychagnostus barrandei (Hicks), Rushton, 1979, p. 54, fig. 5A-B; Morris, 1988, p. 195

Onymagnostus altus (Grönwall), Öpik, 1979, p. 107

Onymagnostus ciceroides (Matthew), Öpik, 1979, p. 107; Robison, 1984, p. 51; Morris, 1988, p. 155

Onymagnostus convexus (Westergård), Öpik, 1979, p. 107

not Triplagnostus convexus Westergård; Egorova, Pegel \&

Chernysheva in Egorova et al., 1982, p. 65, pl. 2, figs 5, 7 [?= Pseudophalacroma lundgreni (Tullberg)]

Cotalagnostus aff. altus (Grönwall); Egorova, Pegel \& Chernysheva in Egorova et al., 1982, p. 73, pl. 8, figs 3, 8

Onymagnostus pseudomundus Xiang \& Zhang, 1985, p. 76, pl. 16 , figs 12,13

Lectotype. Specimen figured by Hicks (1872, pl. 5, fig. 5) and Lake (1906, pl. 2, fig. 2), selected by Rushton (1979, p. 54).

New material. More than a hundred specimens are in GGU 298969, 298970, 298974, 298975, 319789, and 319790 .

Emended diagnosis. Lejopyge with variable effacement of features on acrolobes. Cephalon and pygidium semicircular, highly convex, nonspinose. Axial furrow of cephalon weakening anteriorly, shallow to nearly effaced laterally, indistinct or effaced around anteroglabella; transglabellar furrow (F3) weak to effaced. Posteroglabella broad, subparallel sided; median node anterior from midpoint. Basal lobes simple. Genae usually smooth; preglabellar median furrow effaced. Cephalic border narrow. Axial furrow of pygidium variable in depth, but distinct, ranging from moderately deep to almost effaced. Pygidial axis relatively short for genus, well rounded posteriorly on later holaspides; F1 moderate to shallow in depth, bowed anteriorly; F2 shallow to effaced, indented by median tubercle of $\mathrm{M} 2$ that may have superimposed node. Postaxial median furrow usually absent on holaspides. Pygidial border moderate to narrow in width.

Remarks. L. barrande i is a species of Lejopyge characterised by intermediate and variable effacement of furrows on the acrolobes. The degree of effacement increased during ontogeny, especially on the cephalon, which has been noted in populations from Sweden (Westergård, 1946, p. 73) and Newfoundland (Hutchinson, 1962, p. 85 ), and is clearly evident in populations from North Greenland. Also, the degree of effacement may be influenced by taphonomy, seemingly being enhanced by compression in argillaceous matrix (Fig. 23.4, 6, 9, 11). Such variability has contributed to a proliferation of taxonomic names from widespread localities (see synonymy).

Some specimens of L. barrandei and Cotalagnostus lens are similarly effaced, making their identification difficult. Usually, however, $L$. barrandei has narrower cephalic and pygidial borders of more uniform width, lacks a postaxial median furrow, and the pygidial F1 is usually evident and clearly deeper than the F2.

Occurrence. L. barrandei, as emended, has been reported from England, Wales, Canada (eastern Newfoundland), Greenland (Nyeboe Land), Denmark, Sweden, Russia (Siberia), and China (Xinjiang). The new material is from the upper Henson Gletscher and the basal Kap Stanton formations of Nyeboe Land. The composite observed stratigraphic range of the species is throughout most of the Ptychagnostus atavus and Ptychagnostus punctuosus zones.

\section{Lejopyge calva Robison, 1964 \\ Fig. 24}

Remarks. A single effaced cephalon and a fragmentary, associated pygidium in collection GGU 301311 are assigned to $L$. calva (compare Robison, 1984, pp. 40-42, fig. 23.1-8). Although the posterior border on the pygidium is slightly wider than usual for this species, the cephalic features, including degree of effacement of fur- 


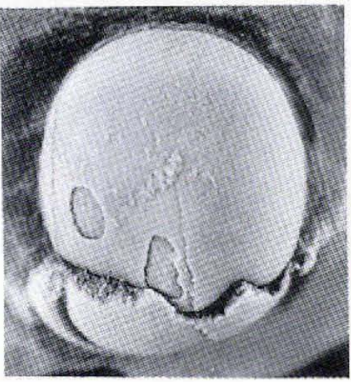

$1 \mathrm{a}$

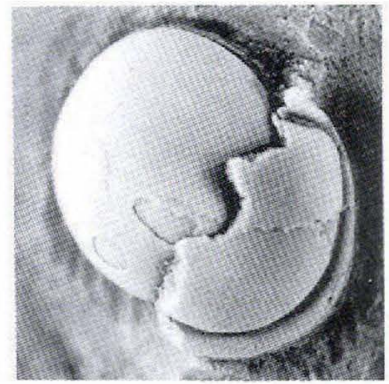

$1 b$

Fig. 24. Lejopyge calva Robison. Slightly exfoliated cephalon (1a) and associated, fragmentary pygidium (1b), MGUH 21.427 from GGU 301311, × 10 .

rows on the acrolobe, are characteristic of the species. The specimen is from near the base of the Kap Stanton Formation in Peary Land and is associated with a fauna of the lower Lejopyge laevigata Zone. This is the first report of $L$. calva from Greenland.

Laurie (1989) recently reviewed the species of Lejopyge in Australia, and he reassigned a few Australian specimens to L. calva. Most or all of those specimens, in my opinion, represent Pseudophalacroma as emended here rather than Lejopyge. Specimens of Lejopyge praecox Öpik, 1979 were independently and almost simultaneously reassigned to Lejopyge dubium (Whitehouse) by Robison (1988, p. 49) and to L. calva by Laurie (1989, p. 189). Based on the wide pygidial border of praecox, as well as other features, I still consider it to be a synonym of dubium, but dubium is here reassigned to Pseudophalacroma (see below).

Fig. 25. Lejopyge hybridus (Brøgger). 1, partly exfoliated and tectonically deformed cephalon, MGUH 21.428 from GGU 319790, × 8. 2, partially flattened pygidium with axis possibly narrowed by compression, MGUH 21.429 from GGU $319790, \times 10.3$, questionably assigned, deformed exoskeleton, MGUH 21.430 from GGU 301311, × 6. 4, questionably assigned, flattened exoskeleton, MGUH 21.431 from GGU 298969, × 8 .

Lejopyge hybridus (Brøgger, 1878)

Fig. 25.1, 2, 3?, 4?

New material. More than 30 specimens are in GGU 319790 and 6 questionably assigned specimens are in GGU 298969 and 301311.

Remarks. The species diagnosis of Robison (1984, pp. 51-54) is followed here, although the species is reassigned from Onymagnostus to Lejopyge. A synonymy and taxonomic discussion were included with that diagnosis. Lauric (1988, pp. 187-189) subsequently published a shorter but essentially similar diagnosis under the name Onymagnostus hybridus. In referring to my 1984 list of synonyms, Laurie noted some assignments that he stated to be incorrect. Of those, I agree that one specimen from Utah, which was previously illustrated as Ptychagnostus hybridus (Robison, 1964, pl. 79, fig. 11), is a representative of Doryagnostus (see remarks on Doryagnostus). Laurie further noted that the holotype of Triplagnostus formosus Pokrovskaya \& Khajrullina in Repina et al. (1975, pl. 9, fig. 9), which in 1984 I reassigned to hybridus, probably also belongs to Doryagnostus. I concur with that probability, but am unable to make a firm judgment from available illustrations. The inclusion of $T$. formosus in Laurie's (1988, p. 187) list of synonyms of O. hybridus indicates a generic assignment that is contrary to that made in his remarks (p. 188-189).

A few Australian taxa that I listed in 1984 as synonyms of Onymagnostus hybridus were reassigned by Laurie (1988, p. 189) as synonyms of $O$. mundus Öpik, 1979. Laurie stated that $O$. mundus and taxa that he synonymised with it "are all very similar but differ from $O$.
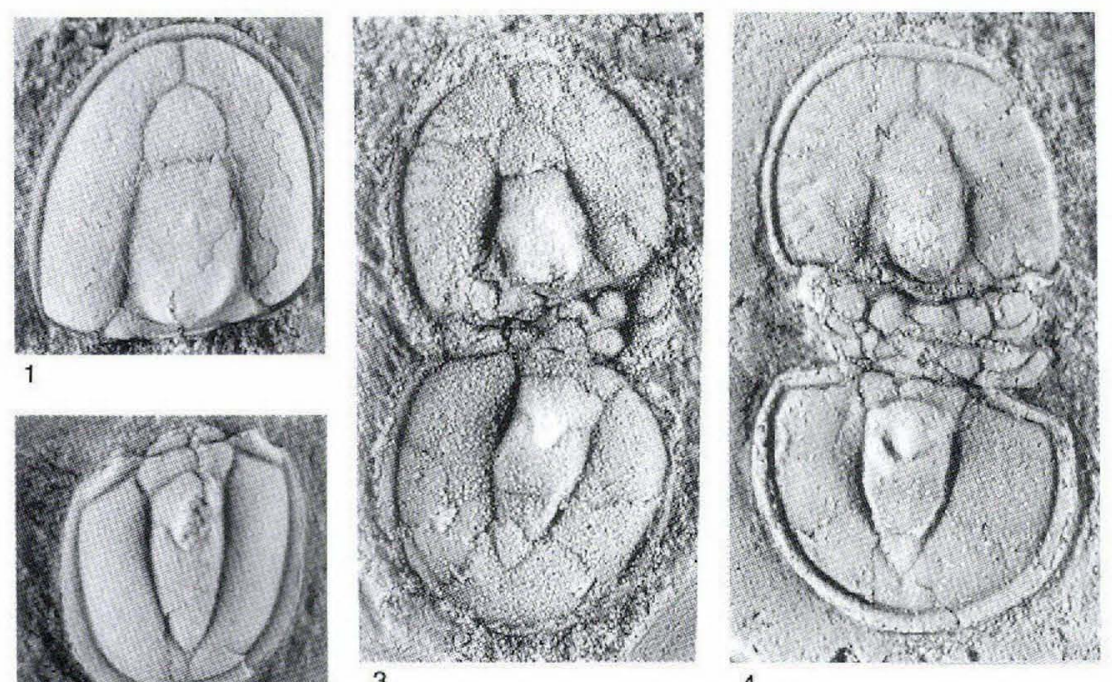

3

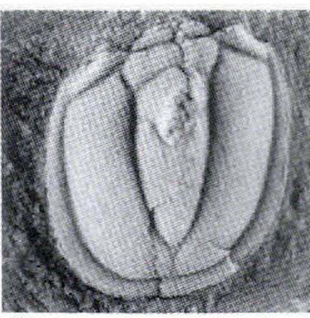

2 


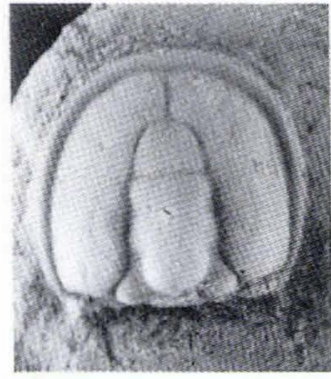

$1 \mathrm{a}$

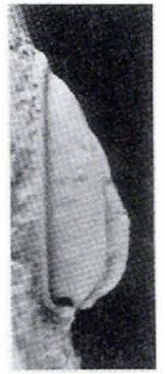

1b

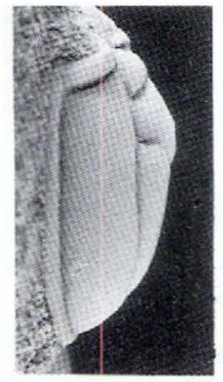

2a

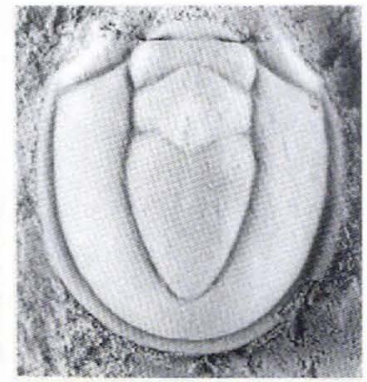

$2 \mathrm{~b}$
Fig. 26. Lejopyge cf. seminula (Whitehouse) from GGU 298970. la, b, cephalon in dorsal and lateral views, MGUH 21.432, × 10. 2a, b, pygidium in lateral and dorsal views, MGUH $21.433, \times 6$. hybridus ... in having very weakly impressed axial furrows and in having a narrower, less bluntly pointed anterior glabellar lobe." In large populations of hybridus that I have observed, depth of the axial furrow is variable, and the average depth varies from population to population. The shape of the anterior glabella also is variable. With regard to anterior glabellar shape, Laurie (1988, pp. 187, 189) used identical wording, "rounded to obtusely pointed," in describing that character in his diagnoses of both $O$. hybridus and $O$. mundus. Therefore, I continue to suppress $O$. mundus as a subjective junior synonym of $L$. hybridus.

The new specimens from Greenland provide no new information about morphology of the species.

Occurrence. $L$. hybridus is a common, widely distributed species in open-marine lithofacies. Several new specimens are from basal beds of the Kap Stanton Formation in Nyeboe Land (e.g., Fig. 25.1, 2), one questionably assigned specimen is from the basal Kap Stanton Formation in Peary Land (Fig. 25.3), and a few other questionably assigned specimens are from the upper Henson Gletscher Formation in Nyeboe Land (e.g., Fig. 25.4). The assigned specimens are from the Ptychagnostus atavus Zone. The questionably assigned specimens are mostly from the Ptychagnostus atavus Zone, but one is from the lower Lejopyge laevigata Zone.

\section{Lejopyge cf. seminula (Whitehouse, 1939) Fig. 26}

Remarks. Eleven specimens in GGU 298970 have morphological characters that appear to be transitional between those of Lejopyge seminula and L. hybridus (compare Robison, 1984, pp. 51-55, figs 30-32). They resemble specimens of $L$. seminula by having slightly elongate basal lobes, but length of the axial lobe is more similar to that of $L$. hybridus. Therefore, their assignment to a species is problematic.

The new specimens are from the middle Henson Gletscher Formation of Nyeboe Land, and they probably are from the uppermost Ptychagnostus gibbus Zone. This biostratigraphic occurrence is intermediate between ranges previously observed for $L$. seminula and $L$. $h y$ bridus (Robison, 1984, pp. 54-55).

\section{Genus Pseudophalacroma Pokrovskaya, 1958}

Pseudophalacroma Pokrovskaya, 1958, p. 79; Öpik, 1961, pp. 90-92; Öpik, 1967, p. 77; Öpik, 1979, p. 163; Qiu et al., 1983, p. 38; Lu \& Lin, 1989, pp. 100-101, 218-219

Type species. Pseudophalacroma crebra Pokrovskaya, 1958, pp. 79-80; by original designation $[=P$. dubium (Whitehouse, 1936), see Robison, 1988, p. 49].

Emended diagnosis. Ptychagnostidae with furrows of acrolobes well developed to mostly effaced. Glabella short, moderately and rather evenly tapered, anteriorly acute. Basal lobes simple. Genae usually smooth. Cephalic border narrow to thread-like. Pygidial axis short, F1 deeper than F2; posteroaxis lanceolate to slightly ogival. Postaxial median furrow present if posterior axial furrow is not effaced. Pygidial border moderate to narrow in width; widest medially, gradually narrowing toward anterior corners. Spines may be present on cephalon, thorax, and pygidial axis; not observed on pygidial border.

Remarks. Parts of the preceding diagnosis necessarily pertain only to species that lack much effacement of furrows on the acrolobes. Such species first appear in the Ptychagnostus punctuosus Zone, and are present only in the lower stratigraphic range of Pseudophalacroma as emended.

Pseudophalacroma seems to be a monophyletic (holophyletic) genus that commenced with $P$. lundgreni. The origin of $P$. lundgreni within the Ptychagnostidae remains unclear, but it possibly arose from Ptychagnostus intermedius (see Robison, 1984, 46, fig. 6). Other species, as in Lejopyge, may retain the original furrowed condition 
or may show variable effacement of acrolobe features. Furrowed species are characterised by a relatively short axial lobe. The glabella tapers to an acute point, and a median node is posterior from the posteroglabellar midpoint. A prominent postaxial median furrow separates the pleural lobes on such furrowed species as $P$. lundgreni and $P$. rigbyi, and a vestige is evident on some exfoliated internal moulds of effaced species (Öpik, 1979, pl. 65, figs 1,2 ; pl. 67, fig. 3; Robison, 1988, fig. 11.2). Characters that differentiate species of Pseudophalacroma and Lejopyge are discussed above in remarks on Lejopyge.

Species here included in Pseudophalacroma are $P$. dubium (Whitehouse, 1936), P. lundgreni (Tullberg, 1880), P. multifora (Öpik, 1979), P. ovalis (Yang, 1982), and $P$. rigbyi (Robison, 1984). Pseudophalacroma triangularis Ju in Zhang, 1983 and $P$. breviovata Ju in Zhang, 1983 are here considered to be junior synonyms of $P$. ovalis. The genus has an observed stratigraphic range from near the base of the Ptychagnostus punctuosus Zone to near the top of the Lejopyge laevigata Zone. It is widely distributed in open-oceanic lithofacies.

Dong (1990, p. 318, pl. 3, fig. 12) illustrated an agnostoid pygidium from western Hunan, China, as Pseudophalacroma triangularis $\mathrm{Ju}$, and applied the same name to a new zone in upper Middle Cambrian strata of that region. With regard to the synonymy cited above, the zone named by Dong now should be called the Pseudophalacroma ovalis Zone. According to Song (1989, fig. 7), the Chinese stratigraphic interval containing $P$. ovalis questionably correlates with the Ptychagnostus punctuosus Zone as used in other parts of the world.

Although new specimens of Pseudophalacroma are not described here, an emended generic diagnosis is included for comparison with the emended diagnosis of Lejopyge, given above. Specimens from the Holm Dal Formation in North Greenland that were previously assigned (Robison, 1988, pp. 48-49, fig. 11.1-4) to Lejopyge dubium (Whitehouse) are here reassigned as $P$ seudophalacroma dubium.

\section{Genus Ptychagnostus Jaekel, 1909}

Type species. Agnostus punctuosus Angelin, 1851, p. 8.

Remarks. The generic diagnosis and description of Ptychagnostus by Robison (1984, pp. 12-13) are followed here. More restricted diagnoses of Ptychagnostus have been published by Laurie (1988, pp. 171-172) and Shergold et al. (1990, p. 39), who reassigned some species to five other genera or subgenera (Triplagnostus Howell 1935c, Pentagnostus Lermontova, 1940, Acidusus Öpik, 1979, Aotagnostus Öpik, 1979, and Zeteagnostus Öpik,
1979) that I continue to regard as junior synonyms of Ptychagnostus. My reasons for this synonymy remain unchanged from those expressed in 1984.

Shergold \& Laurie (1991) have petitioned the Interna tional Commission on Zoological Nomenclature to use its plenary powers to conserve the name Ptychagnostus.

\section{Ptychagnostus affinis (Brøgger, 1878)}

Figs $10.5 ; 27.1,2$

New material. Two cephala and 2 pygidia are in GGU 319789 and 319790.

Remarks. The emended diagnosis of $P$. affinis by Robison (1984, pp. 16-17) is followed here. Laurie (1988, pp. 172-176) subsequently discussed the species and made corrections to its synonymy, with which I concur. The new specimens are all fragmentary.

Occurrence. The geographic and stratigraphic distributions of $P$. affinis were reviewed by Robison (1984, p. 17). With a correction by Laurie (1988), the species is no longer known from Alaska.

The new specimens are the first representatives of $P$. affinis to be reported from Greenland. All are from basal beds of the Kap Stanton Formation in Nyeboe Land, and are from the upper Ptychagnostus atavus Zone.

\section{Ptychagnostus atavus (Tullberg, 1880) Fig. 27.5, 6}

New material. Two cephala and 2 pygidia are in GGU 319790.

Remarks. The emended diagnosis of $P$. atavus by Robison (1984, pp. 18-21) is followed here. A similar diagnosis was subsequently published by Laurie (1988, p. 180 ), but he reassigned the species to Acidusus. I agree with Westergand (1946, p. 68) that the species atavus, affinis and punctuosus "constitute a fairly continuous evolutional series," and like Westergård I assign them all to Ptychagnostus. $P$. affinis primarily differs from $P$. atavus by the more anterior position of the median node on the glabella, a weaker tubercle on the pygidial M2, and development of weak granulation on the pleural fields. In my opinion, these are characters that are appropriate for defining species, but not genera. Moreover, difference in position of the glabellar node may represent differential expression of latent nodes rather than evolutionary migration of one node (see Robison, 1984, p. 17).

Occurrence. $P$. atavus is a common, widely distributed species in open-oceanic lithofacies. The new specimens 


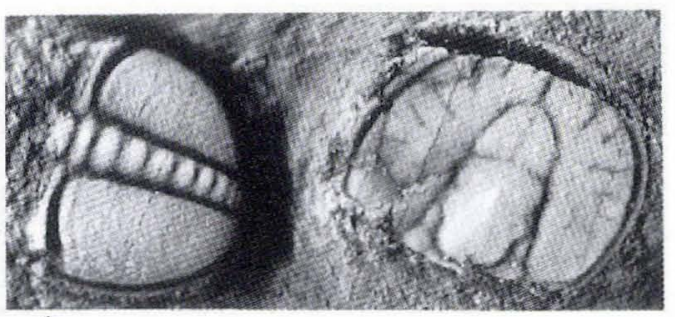

1

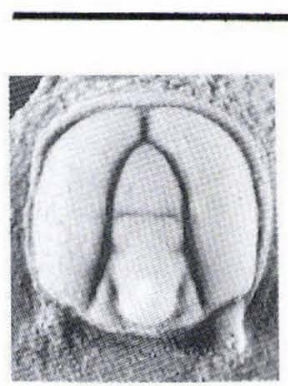

3

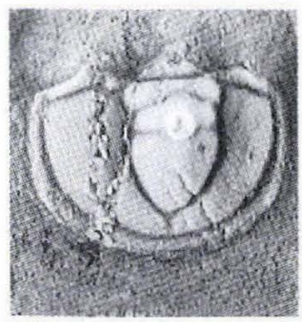

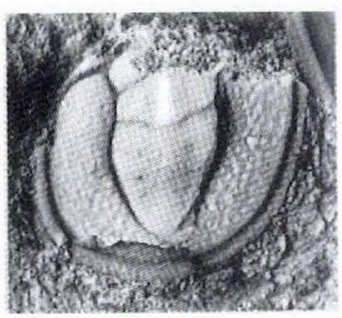

2 are the first to be reported from Greenland. All are from basal beds of the Kap Stanton Formation in Nyeboe Land, and are from the upper Ptychagnostus atavus Zone.

\section{Ptychagnostus gibbus (Linnarsson, 1869)} Fig. 27.3, 4

New material. More than 10 disarticulated specimens are in GGU 298970.

Remarks. The diagnosis of $P$. gibbus by Robison (1984, pp. 22-24) is followed here. Additional synonyms, mostly from Australia, were listed and discussed by Laurie (1988, pp. 196-198). He, however, assigned the species to Triplagnostus, which I consider to be a junior synonym of Ptychagnostus.

The new specimens from Greenland mostly are small and not well preserved.

Occurrence. The new specimens of $P$. gibbus are from the middle Henson Gletscher Formation of Nyeboe Land, and are from the P. gibbus Zone.
Fig. 27. Some species of Ptychagnostus.

1, 2, Ptychagnostus affinis (Brøgger). 1, damaged cephalon (right), MGUH 21.434, associated with pygidium of Eodiscus scanicus (Linnarsson), MGUH 21.303, from GGU $319789, \times 12.2$, fragmentary pygidium, MGUH 21.435 from GGU $319790, \times 10$.

3, 4, Ptychagnostus gibbus (Linnarsson), both from GGU 298970. 3, cephalon, MGUH 21.436, × 12. 4, damaged pygidium, MGUH 21.437. $\times 10$.

5. 6. Ptychagnostus atavus (Tullberg), both from GGU 319790. 5a, b, cephalon in dorsal and lateral views, MGUH 21.438, × 12.6, pygidium, MGUH 21.439, × 12 .

7. 8, Ptychagnostus intermedius (Tullberg), both from GGU 298970. 7, cephalon, MGUH 21.440, × 10. 8 , pygidium, MGUH 21.441, × 10 .
Ptychagnostus intermedius (Tullberg, 1880) Fig. 27.7, 8

New material. More than 20 disarticulated specimens are in GGU 298970.

Remarks. Laurie (1988, p. 178) has suggested that Tullberg's syntypes of Agnostus intermedius may be conspecific with Ptychagnostus affinis (Brøgger, 1878), and he $(1988$, p. 172) listed A. intermedius as a questionable synonym of $P$. affinis. He also reassigned to Zeteagnostus scarifatus (Öpik, 1979) specimens that I (Robison, 1982, 1984) previously assigned to Ptychagnostus intermedius (Brøgger). Laurie further suggested that Z. scarifatus may be a junior synonym of Ptychagnostus sinicus Lu 1957. These suggestions warrant additional investigation, but pending their verification. I continue to follow an earlier diagnosis (Robison, 1984, pp. 25-28) of $P$. intermedius.

The new specimens from Greenland fall well within the range of variation shown by other populations of $P$. intermedius. 
Occurrence. The new specimens of $P$. intermedius are from the middle Henson Gletscher Formation of Nyeboe Land, and are from the Ptychagnostus gibbus Zone.

\section{Genus Tomagnostus Howell, 1935c}

Tomagnostus Howell, 1935c, p. 15; Whitehouse, 1936, p. 90; Harrington, 1938, pp. 149, 154; Kobayashi, 1939, pp. 149 150; Westergård, 1946, pp. 31, 58; Pokrovskaya, 1958, pp. 20-23; Howell in Harrington et al., 1959, p. O175; Pokrovskaya in Chernysheva, 1960, p. 57; Rushton, 1979, pp. 54-55; Shergold et al., 1990, p. 41

Type species. Agnostus fissus Linnarsson, 1879, p. 23.

Emended diagnosis. Ptychagnostidae with furrowed acrolobes. Glabella slightly to moderately tapered; anteroglabella usually having frontal sulcus; posteroglabella with median node or carina, F1 and F2 variably developed. Basal lobes slightly elongate, poorly defined anteriorly, and indenting glabella. Preglabellar median furrow weakening anteriorly or effaced. Genae having scrobiculae or irregular pits, or both. Cephalic border narrow. Pygidial axis having hexagonal M2; posteroaxis sulcate. Postaxial median furrow present or absent in middle and late holaspid stages. Pygidial border narrow, rarely collared. Remarks. Tomagnostus has been variously assigned to the Agnostidae, Diplagnostidae, Peronopsidae, and Ptychagnostidae (see Rushton, 1979, p. 55; Shergold et al., 1990, p. 41). Based on all characters, but with emphasis on those of the axial lobe, I concur with Shergold et al. (1990) in assigning Tomagnostus to the Ptychagnostidae. Comparative morphology suggests that early species of Tomagnostus are most closely related to early species of the ptychagnostid Lejopyge, as emended above. Details of cladogenesis, however, remain obscure.

Species here included in Tomagnostus are T. fissus (Linnarsson, 1879), T. perrugatus (Grönwall, 1902), T. corrugatus (Illing, 1916), T. gracilis (Illing, 1916), T. bothrus n. sp., and questionably T. sibiricus Pokrovskaya \& Egorova in Savitsky et al., 1972. Tomagnostus tchateriensis Kryskov in Borovikov \& Kryskov, 1963 was reassigned to Innitagnostus by Öpik (1967, p. 98), but Innitagnostus is here considered to be a junior synonym of Micragnostus (see remarks on Agnostus). Tomagnostus clarus Egorova \& Pokrovskaya (in Egorova et al., 1982) is reassigned to Schismagnostus n. gen. (see below).

Although Tomagnostus is a widespread genus, its distribution suggests that it may have been mostly or entirely adapted to cool-water habitats, but ranging in depth from shallow to deep. The genus has an observed stratigraphic range from the Ptychagnostus gibbus Zone to the
Ptychagnostus atavus Zone, and questionably into the basal Ptychagnostus punctuosus Zone.

Tomagnostus bothrus n. sp.

Fig. 28.1-5, 7, 6?, 8?

Etymology. Greek bothros, pit; referring to the many scrobicular pits on the genae.

Holotype. Cephalon (Fig. 28.4a, b), MGUH 21.445 from GGU 298970.

Material. Six cephala and 2 questionably assigned pygidia are in GGU 298969 and 298970.
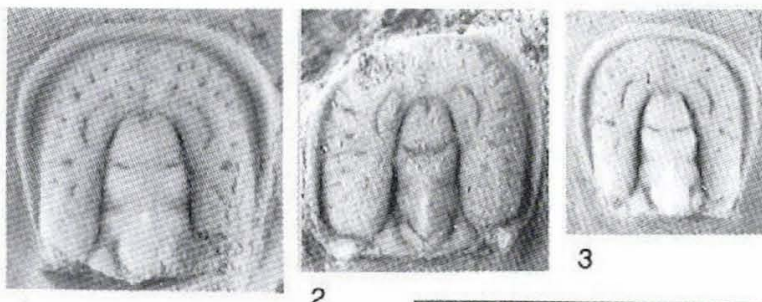
3

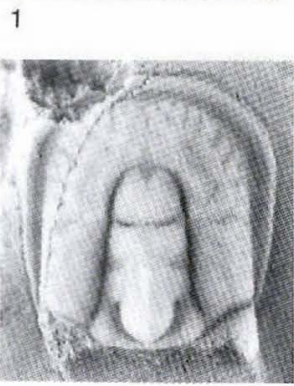

$4 b$

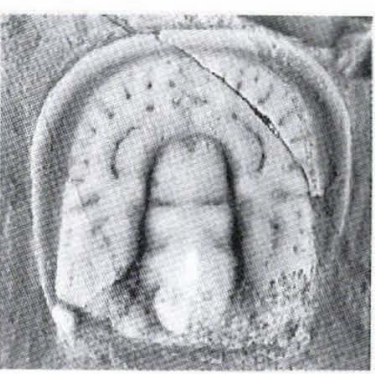

7 $4 a$

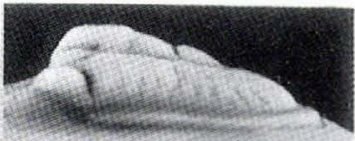

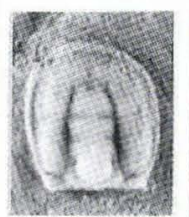

5

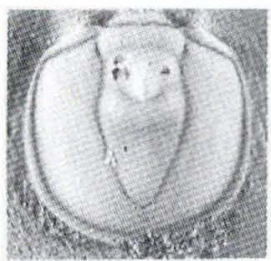

6

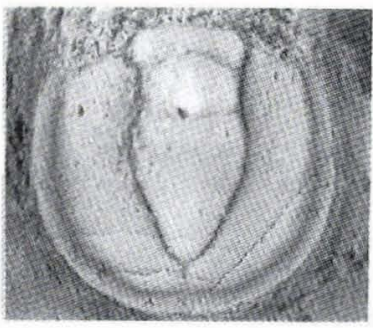

8
Fig. 28. Tomagnosius bothrus n. sp. All specimens are from GGU 298970, unless otherwise stated. 1, cephalon, MGUH 21.442, × 8. 2, cephalon, MGUH 21.443 from GGU 298969, $\times$ 8. 3, cephalon, MGUH $21.444, \times 8.4$, holotype cephalon in lateral and dorsal views, MGUH 21.445, $\times 8.5$, small holaspid cephalon, MGUH 21.446, × 10. 6, questionably assigned pygidium, MGUH 21.447 from GGU 298969, × 8. 7, large holaspid cephalon, MGUH 21.448, $\times 7$. 8, questionably assigned pygidium, MGUH 21.449, $\times 7$. 
Diagnosis. Tomagnostus with moderate convexity. Cephalon having narrow glabella, many scrobicular pits on genae, and posterolateral border spines. Questionably assigned pygidium with elliptical tubercle that is most tumid posteriorly, and with postaxial median furrow throughout holaspid period.

Description. Cephalon subquadrate. Glabella only slightly tapered; transverse furrow (F3) slightly bowed posteriorly, shallow medially, deep laterally. Anteroglabella semicircular to subtriangular, with moderately developed frontal sulcus. Posteroglabella having relatively well-developed F1 and F2 furrows; posterior end strongly rounded, distinctly constricted between basal lobes;

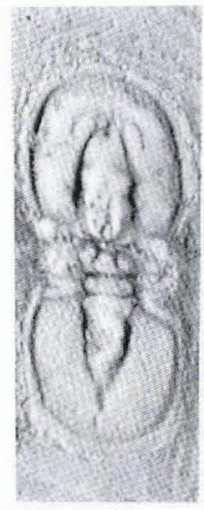

1
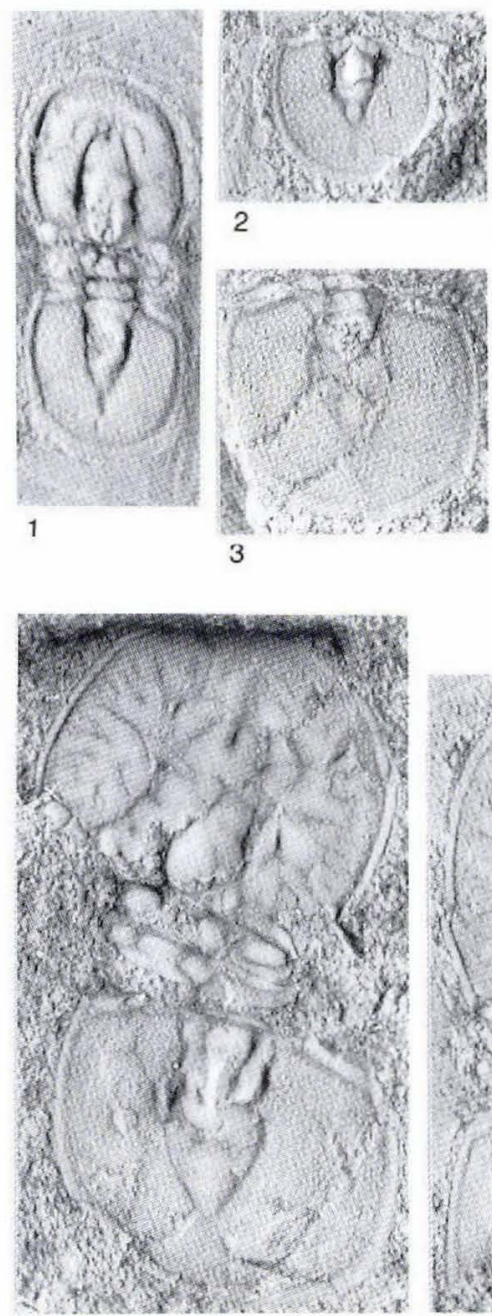

5

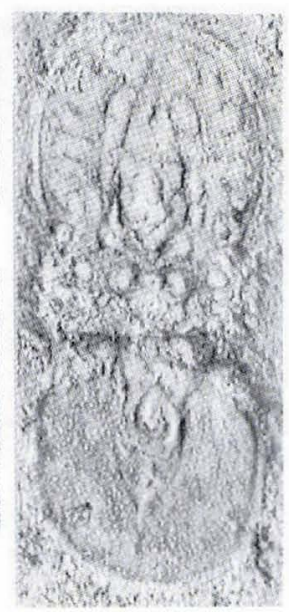

4

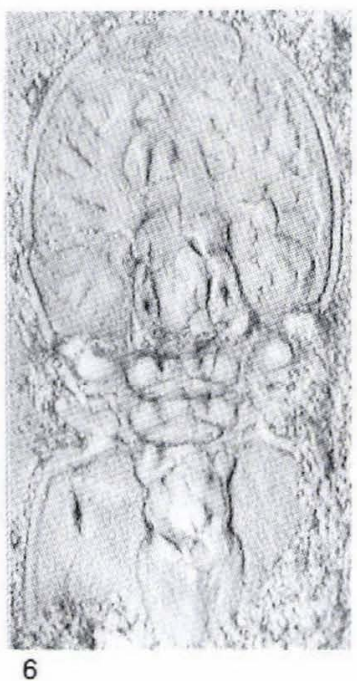

Fig. 29. Tomagnostus corrugatus (Illing). All specimens from GGU 298969. 1, small holaspid, MGUH 21.450, × 10. 2, pygidium, MGUH 21.451, ×8.3, pygidium with tiny incipient spine on right-posterolateral margin. MGUH 21.452, $\times 8.46$, flattened dorsal exoskeletons, MGUH 21.453-21.455, all $\times 8$. median node subcentral, near front of M2, and may be connected to occipital band by thread-like median ridge. Preglabellar median furrow effaced except for weak posterior vestige. Genae with many scrobicular pits, some outlining pair of uninterrupted, arcuate regions on anterior genae; pits on inside of arcuate regions usually coalesced into pair of arcuate grooves opposite front of glabella. Border narrow, with pair of short, stout, posterolateral spines on larger holaspides.

Thorax unknown.

Questionably assigned pygidium subquadrate to subcircular. M2 having elliptical tubercle that is low and poorly defined anteriorly. Posteroaxis long and ogival. Postaxial median furrow present in late holaspid stage. Border narrow and nonspinose.

Remarks. T. bothrus differs from all previously described species of Tomagnostus by having a pair of cephalic border spines. Two pygidia, which are questionably assigned to this species, have characteristic features of the genus except for retention of a postaxial median furrow in late ontogenetic stages.

The cephalon of $T$. bothrus further differs from that of T. fissus by having a narrower glabella and the genal prosopon is predominantly pits rather than grooves. The questionably assigned pygidia of $T$. bothrus differ from those of $T$. fissus by having a more pointed and better defined axial tip.

Larger holaspid cephala of $T$. bothrus resemble those of Schismagnostus plicatus n. gen. \& n. sp. in general axial structure, but differ by the presence of a frontal sulcus, the F3 is nearly straight rather than bowed posteriorly, and the M1 is more constricted between the basal lobes. Other differences are the presence of border spines, longer basal lobes, and a different style of genal scrobiculae in $T$. bothrus. In axial shape, the questionably assigned pygidia of $T$. bothrus resemble those of Ptychagnostus affinis and $P$. punctuosus, but in low-incident light they show no evidence of surface granulation, which characterises the latter species.

Occurrence. The few specimens of $T$. bothrus are from the upper Henson Gletscher Formation in Nyeboe Land, and are from both the Ptychagnostus gibbus and Ptychagnostus atavus zones.

\section{Tomagnostus corrugatus (Illing, 1916)} Fig. 29

Agnostus corrugatus Illing, 1916, pp. 409-410, pl. 29, figs 4, ?5, $6-9$

Tomagnostus corrugatus (Illing), Kobayashi, 1939, p. 149; Pok- 
rovskaya, 1958, pp. 27-30, pl. 2, figs 1-4; Rushton, 1979, p. 56 , figs $6 \mathrm{~A}-\mathrm{B}, 7 \mathrm{D}-\mathrm{E}$

Tomagnostus deformis Pokrovskaya; Egorova, Pegel \& Chernysheva in Egorova et al., 1982 (in part), pl. 8, fig. 9; (not pl. 5, fig. 5; ?not pl. 12, fig. 13)

New material. More than 15 specimens, most flattened and poorly preserved, are in GGU 298969.

Emended diagnosis. Tomagnostus having thin exoskeleton of low convexity. Cephalon with moderately tapering glabella and well-developed genal scrobiculae. Pygidium having short and narrow axis, densely granular pleural fields, and may have pair of incipient marginal spines.

Remarks. All recorded specimens of $T$. corrugatus are preserved in fine-grained matrix and show evidence of taphonomic compression. Compared with associated agnostoids, the new specimens from Greenland are significantly more flattened and seem to have had a thinner exoskeleton. A paucity of taphonomically produced wrinkles, however, suggests that low convexity of the exoskeleton, and especially the pygidium, is a primary character.

Occurrence. $T$. corrugatus has been previously reported from the Ptychagnostus atavus Zone of England and
Russia (Siberia). The new specimens are from the upper Henson Gletscher Formation in Nyeboe Land, and also are from the $P$. atavus Zone.

\section{Tomagnostus fissus (Linnarsson, 1879)}

Fig. 30

Agnostus fissus Linnarsson, 1879, p. 23, pl. 2, fig. 34; Tullberg, 1880, 16, pl. 1, fig. 3a-d; Linnarsson, 1883, p. 31; Matthew, 1896, pp. 230-231; Lake, 1906, pp. 3-4, pl. 1, figs 1-3; Illing, 1916, pp. $406-407$, pl. 28 , figs 6-8; Nicholas, 1916, p. 452 Agnostus fissus trifissus Matthew, 1896, pp. 231-232, pl. 16, fig. 10

?Agnostus fissus var. perrugatus Grönwall, Illing, 1916, p. 407, pl. 28 , fig. 9

Tomagnostus fissus (Linnarsson), Howell, 1935c, p. 15, figs 9. 10; Kobayashi, 1939, p. 149; Westergård, 1946, pp. 58-59, pl. 7, figs 21-29, pl. 16, fig. 8; Pokrovskaya, 1958, pp. 23-27, pl. 1, figs 1-11; Howell in Harrington et al., 1959, fig. 114.4; Pokrovskaya in Chernysheva, 1960, pl. 1, fig. 3; Hutchinson, 1962, pp. 76-77, pl. 7, figs 1-5; Egorova et al., 1976, p. 59, pl. 37 , figs $2-4,11,13$, pl. 38 , fig. 11, pl. 55, fig. 4; Rushton, 1979, fig. 7A-C; Egorova, Pegel \& Chernysheva in Egorova et al., 1982, p. 59, pl. 3, figs 1-4, pl. 4, fig. 1, pl. 6, fig. 6, pl. 8, figs 4-7, pl. 9, fig. 5, pl. 51, figs 7, 8: Kindle, 1982, pl. 1.2, figs 6, 10: Morris, 1988, p. 229; Shergold et al., 1990, fig. 12.6a, b; Samson et al., 1990, p. 1467, fig. 5C-E
Fig. 30. Tomagnostus fissus (Linnarsson). All specimens from GGU 298970, unless otherwise stated, and all $\times 8$. 1, latex cast of partially flattened exoskeleton, MGUH 21.456. 2a, b, dorsal and lateral views of cephalon, MGUH 21.457. 3, large holaspid cephalon, MGUH 21.458. 4, cephalon with pattern of genal scrobiculae similar to that described for Tomagnostus fissus trifissus (Matthew), MGUH 21.459 from GGU 298975. 5, 6, smaller holaspid cephala, MGUH 21.460 and 21.461. 7. pygidium, MGUH 21.462. 8a, b, incomplete, large holaspid pygidium in dorsal and lateral views, MGUH 21.463. 9, 10, pygidia, MGUH 21.464 and 21.465.
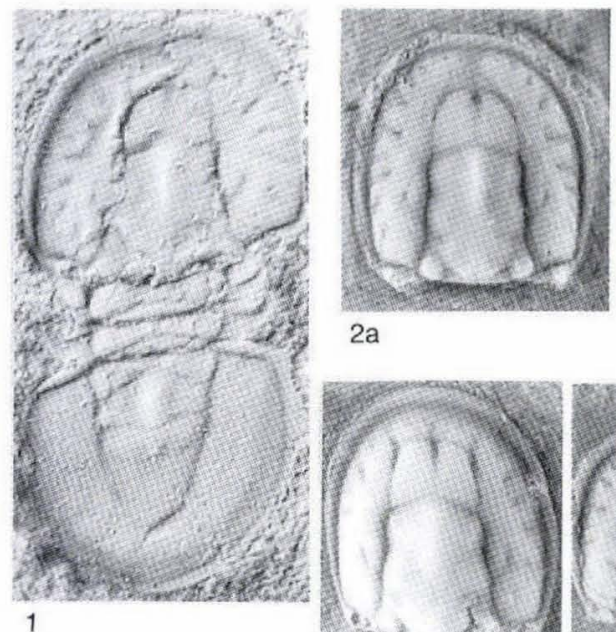

$2 a$

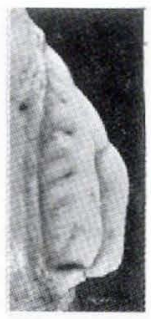

$2 \mathrm{~b}$

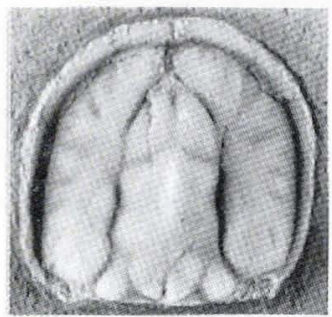

3
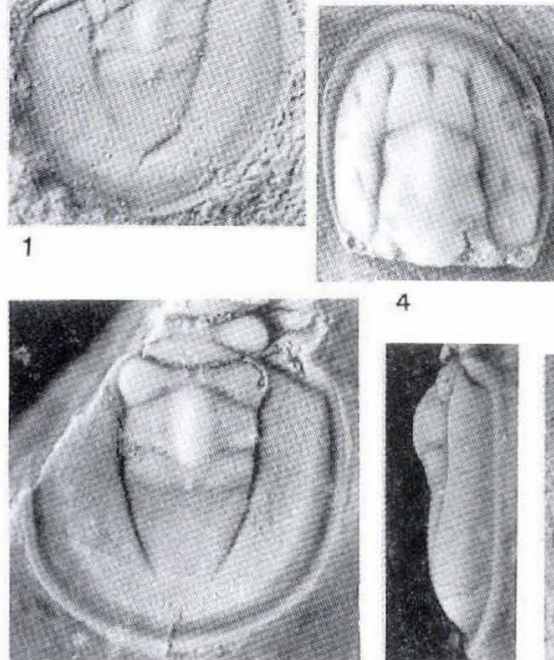

$8 \mathrm{a}$

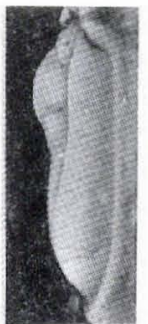

$8 b$

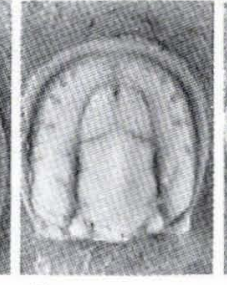

5

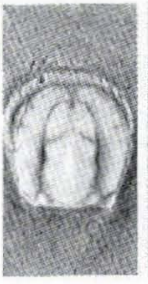

6

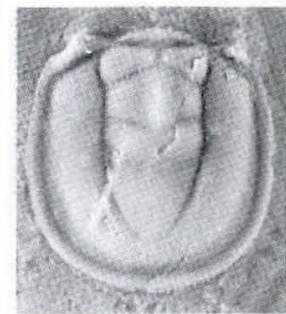

9

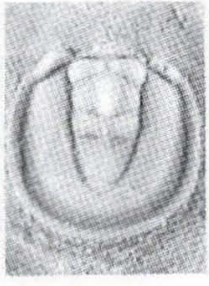

7

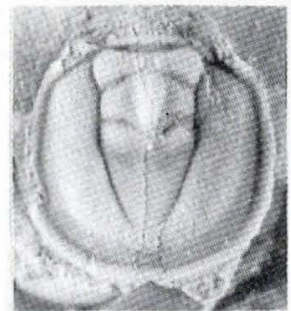

10 
Tomagnostus fissus trifissus (Matthew), Kobayashi, 1939, pp. $149-150$

New material. More than a hundred specimens are in GGU 298969, 298970, 298974, and 298975.

Remarks. T. fissus is characterised by moderate to high cephalic convexity, a wide glabella, a median carina along the front half of the posteroglabella, usually poor to moderate development of genal pits and scrobiculae, and a lack of spines. Additional characters and the considerable morphological variability of $T$. fissus have been well described by Westergård (1946, pp. 58-59). New specimens from Greenland closely resemble those from the type area in Sweden and they show similar variability.

Occurrence. T. fissus is a common species that has been previously reported from Sweden, Norway, Denmark, England, Wales, Canada (eastern \& western Newfoundland), United States (South Carolina), and Russia (Siberia). The new specimens are from the upper half of the Henson Gletscher Formation in Nyeboe Land where they are present in both the Ptychagnostus gibbus and Ptychagnostus atavus zones.

\section{Tomagnostus perrugatus (Grönwall, 1902)} Fig. 31.2, 3, 1?

Agnostus fissus var. perrugata Grönwall, 1902, p. 50, pl. 1, fig. 1

not Agnostus fissus var. perrugatus Grönwall, Illing, 1916, p.

407, pl. 28, fig. 9 [? = Tomagnostus fissus (Linnarsson)] Agnostus sulcatus Illing, 1916, pp. 411-412, pl. 30, figs 3-6 Goniagnostus sulcatus (Illing), Howell, 1935c, p. 14

Tomagnostus perrugatus (Grönwall), Kobayashi, 1939, pp. 149-150; Westergård, 1946, pp. 59-60, pl. 8, figs 1-10; Hutchinson, 1962, p. 77, pl. 7, figs 6-9; Savitsky et al., 1972, p. 60, pl. 5, figs 7-10; Rushton, 1979, pp. 55-56, fig. 6C-E;

Egorova, Pegel \& Chernysheva in Egorova et al., 1982, p. 59 , pl. 17, figs 5, 6, pl. 54, figs 9, 12; Morris, 1988, p. 229

Tomagnostus sulcatus (Illing), Kobayashi, 1939, p. 149

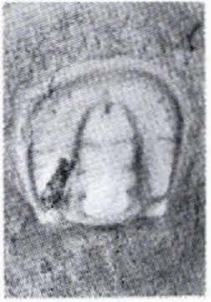

1

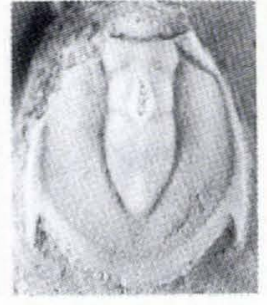

2

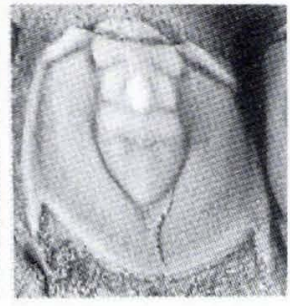

3
Fig. 31. Tomagnostus perrugatus (Grönwall). All specimens from GGU 319790. 1, questionably assigned, small holaspid cephalon, MGUH 21.466, × 10. 2, 3, pygidia, MGUH 21.467 and 21.468 , both $\times 8$.
Tomagnostus deformis Pokrovskaya, 1958, pp. 32-34, pl. 2, figs 5-9; Egorova, Pegel \& Chernysheva in Egorova et al., 1982 (in part), p. 60, pl. 5, fig. 5, ?pl. 12, fig. 13 (not pl. 8, fig. 9)

?Tomagnostus perrugatus West. [sic], Pokrovskaya, 1958, pl. 2, figs 10,11

Agnostus sp. Šnajdr, 1958, p. 70, pl. 46, fig. 3

Tomagnosius renata Fatka et al., 1981, pp. 368-369, pl. 2, figs 3-5

Tomagnostus cf. perrugatus (Grönwall), Fatka \& Kordule, 1992. pl. 2 , fig. 3

New material. Two pygidia are in GGU 319790. One cephalon in GGU 319789 and 2 cephala in GGU 319790 are questionably assigned to this species.

Emended diagnosis. Glabella narrow, tapering only slightly. Genae having many radial scrobiculae (abaxial) and pits (mostly adaxial), pair of arcuate grooves opposite front of glabella, and may have pair of short longitudinal grooves opposite M3. Transverse sulcus of posteroaxis having pair of tiny pits. Pygidial border flat, without or with collar, and with pair of marginal spines.

Remarks. Westergård (1946, pp. 59-60) has described well the morphological variability observed within populations of this species in Sweden. Two new pygidia from Greenland accord closely with his description. Cephala of Tomagnostus associated with the new pygidia are not well preserved and their identification to species is questionable.

Occurrence. Specimens representing $T$. perrugatus have been previously reported from Denmark, Sweden, England, Canada (eastern Newfoundland), Czechoslovakia, and Russia (Siberia). They have a composite observed stratigraphic range from the Ptychagnostus gibbus Zone to the Ptychagnostus punctuosus Zone. The new specimens from Greenland are from basal beds of the Kap Stanton Formation, and are from the Ptychagnostus atavus Zone.

\section{Family unassigned Genus Megagnostus n. gen.}

Etymology. Greek mega, large, plus Agnostus; referring to the exceptionally large size of some specimens.

Type species. Agnostus glandiformis Angelin, 1851, pp. 5-6.

Diagnosis. Cephalon mostly effaced, retaining only vestiges of posterior border furrows; convexity low to moderate. Cephalic doublure narrow. Thorax with anterior segment sagittally longer than posterior segment; axial 
rings transversely wide, effaced. Pygidium characterised by unique doublure that curves inward and downward, forming ventrally projecting flange. Pygidium smaller than cephalon, with acrolobe effaced except for weak median node; convexity low. Border furrow of pygidium well developed or may become effaced posteriorly on large holaspides. Articulating half ring narrow sagittally, wide transversely; width averaging about half that of pygidium. Articulating furrow narrow, shallow. Spines absent.

Remarks. Agnostus glandiformis Angelin, 1851 has been assigned by various authors to at least five different genera (see synonymy below). fllustrations by Lindström (1901, pl. 1, fig. 7), Holm \& Westergård (1930, pl. 1, fig. 4), and Westergård (1946, pl. 15, fig. 10a, b) show this species to have an unusual, prominent flange that projects ventrally from the pygidial doublure. The presence of a border demonstrates that the specimen illustrated by Holm \& Westergård is a pygidium rather than a cephalon as stated in their figure caption. A similar flange is also present on a new agnostoid species from North Greenland (see Fig. 32.9a). This type of flange is considered to be a significant synapomorphous character, and is used with other characters in defining and differentiating the new genus Megagnostus. Included in this genus are $M$. glandiformis (Angelin), $M$. diclidus n. sp., and questionably $M$. resecta (Grönwall).

The prominent ventral flange on the pygidial doublure of Megagnostus is probably part of a coaptive device for interlocking the cephalon and pygidium during enrollment. To my knowledge, a similar device has not been reported in any other agnostoid genus.

A fine, asymmetric, submarginal groove also is present on the interior surface of the pygidial doublure of both $M$. glandiformis (see Fig. 33.4, 5, 12, 13) and $M$. diclidus (see Fig. 32.5, 7). It is commonly seen on internal moulds. Its position is remarkably similar to that of a submarginal suture on the cephalon of the Ordovician agnostoid Arthrorhachis elspethi, examples of which were described and illustrated by Hunt (1966) as Trinodus elspethi. The pygidial doublure of Megagnostus, however, shows no evidence of a functional suture.

In its style and advanced degree of effacement, Megagnostus closely resembles Leiagnostus, a widespread Lower Ordovician genus that has been recently revised by Ahlberg (1988). However, subtle morphological differences and a lack of likely connecting taxa in Upper Cambrian strata suggest that these genera are not closely related. The articulating half ring on the pygidium of Megagnostus is much wider transversely than in Leiagnostus, which may indicate important differences in the effaced axis of each genus. They also differ in such details as convexity of the pygidium and prominence of its median node, which are less in Megagnostus. Further review by Ahlberg (1992) has led to the suggestion that Leiagnostus may be a highly effaced derivative of Lotagnostus from Upper Cambrian strata, and of the family Agnostidae.

Affinities with other agnostoid genera are difficult to assess because of the high degree of both cephalic and pygidial effacement in Megagnostus. Widely spaced points of origin of posterior border furrows on the cephalon and a wide articulating half ring on the pygidium indicate an unusually wide, though mostly effaced axial lobe on both shields. All characters considered, Megagnostus most closely resembles Phalacroma. The phyletic significance of that resemblance is problematic, however, and the family assignment of Megagnostus is left open.

The taxonomic status of Agnostus glandiformis var. resecta Grönwall, 1902 is unclear. Westergård (1946, pp. 93-94, pl. 14, fig. 19) elevated the taxon to species rank and reassigned it to Phalacroma (see also Jago, 1976, p. 146, pl. 24, fig. 12). Additional specimens from Spain were attributed to the species by Sdzuy (1961, pp. 525526, pl. 2, figs 10-13), but he reassigned it to Leiagnostus Jaekel, 1909. Pygidia that have been assigned to the species have a shallower border furrow and narrower border than do pygidia of $M$. glandiformis of comparable size, but are closely similar in other dorsal features. Until more information is available, especially regarding structure of the pygidial doublure, the species is questionably reassigned to Megagnostus.

Megagnostus is known from Sweden, Norway, Denmark, Greenland, Russia (Siberia), the United States (Vermont), Australia (Tasmania), and questionably from Canada (eastern Newfoundland), England, France, and Spain. Assigned specimens are from the Lejopyge laevigata Zone and some questionably assigned specimens (M. ?resecta) are from the subjacent Ptychagnostus punctuosus Zone and possibly older strata.

\section{Megagnostus diclidus n. sp.}

Fig. 32

Etymology. Greek diklidos, double folding; referring to the upturned lateral borders of the pygidium.

Holotype. Pygidium (Fig. 32.9a, b), MGUH 21.477 from GGU 301313.

Material. More than 50 disarticulated specimens are in GGU 301312, 301313, and 313115.

Diagnosis. Cephalon subquadrate, width and length usu- 


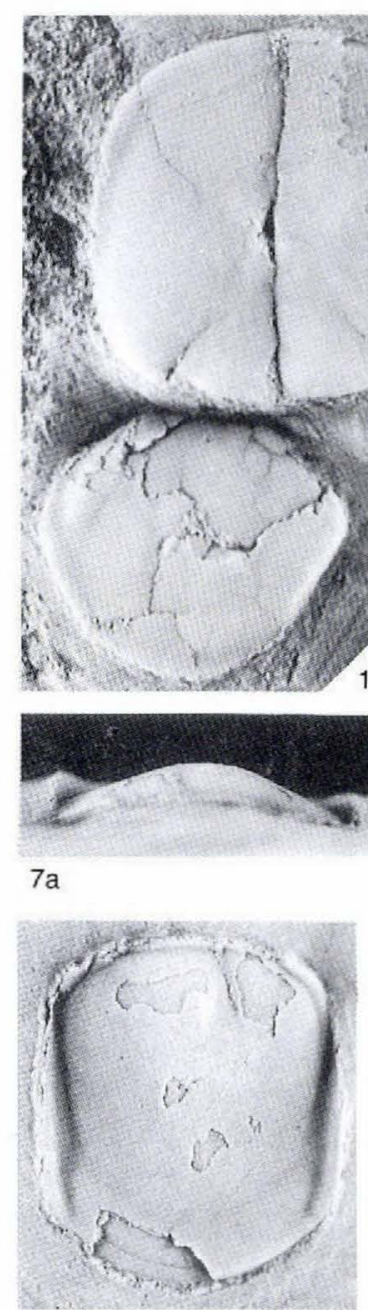

$7 b$

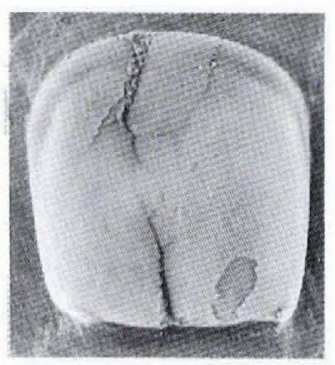

$2 a$

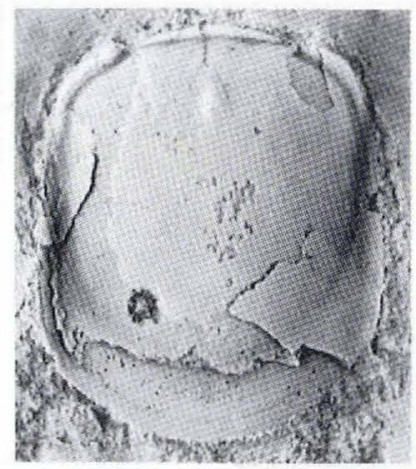

5

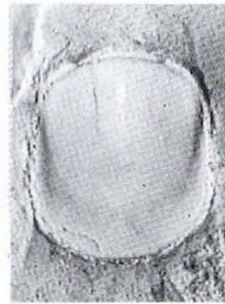

8

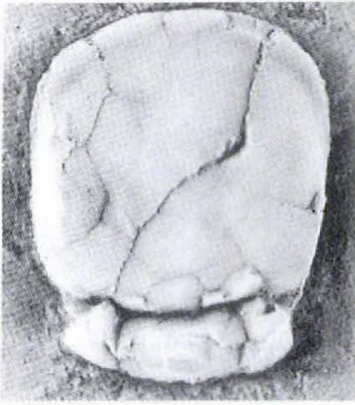

3

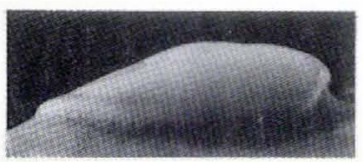

$2 b$

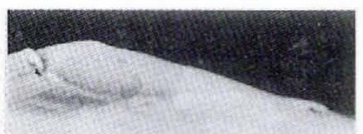

$6 a$

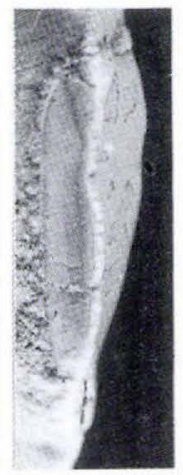

$9 a$

$9 b$

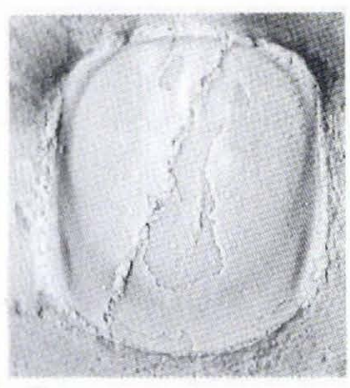

4

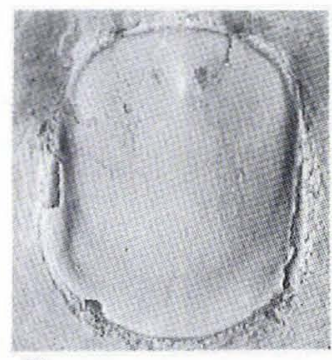

$6 b$

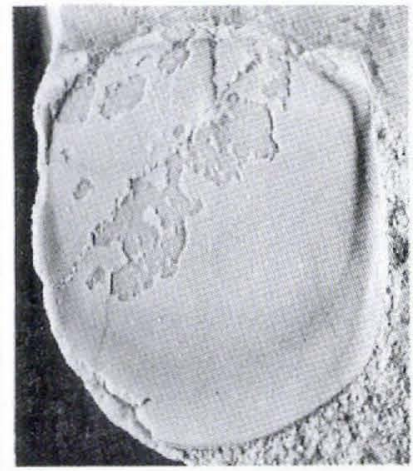

Fig. 32. Megagnostus diclidus n. gen. \& n. sp. All specimens are from GGU 301313, unless otherwise stated. 1, two flattened cephala, MGUH 21.469, × 5. 2a, b, cephalon in dorsal and lateral views, MGUH 21.470 from GGU 313115, $\times 8.3$, cephalon and thorax, MGUH 21.471 from GGU 313115, × 7. 4, 5, pygidia, MGUH 21.472 and 21.473 from GGU 313115, $\times 8$ and $\times 6.6 a$, b, pygidium in lateral and dorsal views, MGUH 21.474, $\times 7.7 \mathrm{a}-\mathrm{c}$, pygidium in frontal (a) and stereographic views (b, c), MGUH $21.475, \times 7.8$, small holaspid pygidium, MGUH $21.476, \times 8.9 \mathrm{a}, \mathrm{b}$, holotype pygidium with exposed ventral flange (a), in lateral and dorsal views, MGUH $21.477, \times 8$.

ally about equal; convexity low. Thorax not known. Pygidium subrectangular, width averaging about 0.9 times that of length; convexity of acrolobe very low; median node elongate. Pygidial borders narrow and upturned laterally, diminishing in height posterolaterally, and undifferentiated posteriorly except in early holaspides.

Remarks. Middle and late holaspid pygidia of $M$. diclidus differ from those of $M$. glandiformis by having more upturned lateral borders and by lacking a differentiated posterior border furrow and border. To my knowledge, form of the late holaspid border of $M$. diclidus is unique among agnostoid trilobites. On early holaspid pygidia of comparable sise, the border and furrow development is similar in M. diclidus (Fig. 32.8) and M. glandiformis (see Fig. 33.9), suggesting close phyletic affinity. Because these two morphs are consistently associated in three collections from the Kap Stanton Formation, sexual dimorphism is a possible explanation for the observed differences. This seems unlikely, however, because the glandiformis morph has been illustrated from several localities around the world, whereas the diclidus morph is known from only North Greenland. The cephalon and pygidium of $M$. diclidus further differ from those of $M$. glandiformis by being less convex, and on average the cephalon is more quadrate and the pygidium is more 
rectangular. In sagittal profile, the pygidium of $M$. dicli$d u s$ is angular with its apex coinciding with its median node (Fig. 32.6a), whereas the pygidium of $M$. glandiformis is broadly rounded with little perceptible change in slope at its median node (see Fig. 33.3b, 12b).

Maximum observed size also differs significantly between $M$. diclidus and $M$. glandiformis. The largest observed cephalon of $M$. diclidus is $7.6 \mathrm{~mm}$ long. The largest cephalon of $M$. glandiformis in GGU collections is $14.0 \mathrm{~mm}$ long, whereas Westergård $(1946$, p. 96) noted that the largest cephalon in Swedish collections is $\mathbf{1 6 . 0}$ $\mathrm{mm}$ long.

Occurrence. All specimens of $M$. diclidus are from basal beds of the Kap Stanton Formation in Peary Land, and are from the lower Lejopyge laevigata Zone.

\section{Megagnostus glandiformis (Angelin, 1851)}

Fig. 33

Agnostus glandiformis Angelin, 1851, pp. 5-6, pl. 6, fig. 1; Brøgger, 1878, p. 74, pl. 6, fig. 7; Tullberg, 1880, pp. 29-30, pl. 2, fig. 20a, b; Lindström, 1901, p. 37, pl. 1, fig. 7; Grönwall, 1902 (in part), pp. 63-64 (not pl. 1, fig. 6); Westergård in Holm \& Westergård, 1930, pp. 10-11, pl. 1, figs $2-5$, pl. 4 , figs $1-3$

Leiagnostus glandiformis (Angelin), Jaekel, 1909, p. 401; Sdzuy, 1961, p. 526

?Agnostus glandiformis Angelin, Illing, 1916, p. 414, pl. 31, fig. 2 [specimen refigured as Grandagnostus sp. by Rushton, 1979, fig. 4C]

Grandagnostus vermontensis Howell, 1935a (in part), p. 221, pl. 22, figs 9?, 10?, 11 (not 8); Howell, 1937 (in part), pp. $1166-1167$, pl. 3, figs 6?, 8?, 9 (not 5); Shaw, 1966, p. 848 , pl. 97 , fig. 10 ?

Grandagnostus glandiformis (Angelin), Howell, 1935a, p. 221; Lermontova, 1940, p. 131, pl. 36, figs 7, 7a-j; Poulsen, 1969, pp. 7-9, figs 7A-C; Jago, 1976, pp. 144-146 [compared with other species in discussion of Valenagnostus], pl. 24, figs 1-5

Phalacroma glandiformis (Angelin), Kobayashi, 1939, pp. 136139

?Grandagnostus longifrons Lermontova, 1940, p. 131, pl. 36, figs $8,8 \mathrm{a}-\mathrm{d}$

Phalacroma glandiforme (Angelin), Westergård, 1946, pp. 95-97, pl. 15, figs 3-17, pl. 16, figs 1, 2; Pokrovskaya, 1958, pp. 53-56, pl. 4, figs 1-6; Pokrovskaya in Chernysheva, 1960, pl. 1, figs 26, 27; Khajrullina, 1970, p. 17, pl. 1, fig. 14; Khajrullina, 1973, pp. 48-49, pl. 3, fig. 15; Egorova, Pegel \& Chernysheva in Egorova et al., 1982, p. 74, pl. 22, ?fig. 6, pl. 23, ?fig. 5, pl. 49, fig. 1 , pl. 55, figs 12,13 , pl. 59, fig. 5, pl. 62 , fig. 9

?Phalacroma maja Pokrovskaya, 1958, pp. 50-51, pl. 4, figs 9-12; Egorova, Pegel \& Chernysheva in Egorova et al., 1982, pp. 74-75, pl. 19, fig. 2, pl. 20, fig. 8, pl. 23, fig. 4, pl. 25, fig. 3 , pl. 40 , fig. 1,2 , pl. 47 , fig. 2,3 , pl. 59 , fig. 4 , pl. 62 , fig. 4 ?Phalacroma longifrons (Lermontova), Pokrovskaya, 1958, pp.
52-53, pl. 4, figs 13-15; Egorova, Pegel \& Chernysheva in Egorova et al., 1982, p. 75, pl. 15, fig. 4, pl. 30, fig. 1

Phalagnostus glandiformis (Angelin), Rosova, 1964, pp. 17-18, pl. 2, figs 14-21, pl. 3, fig. 3; Poulsen, 1966, p. 122; Repina et al., 1975, pp. 118-119, ?pl. 11, figs 20, 21

?Phalagnostus cuneatus Rosova, 1964, pp. 18-19, pl. 2, fig. 22, pl. 3, figs 10-12

?Lejopyge laevigata (Dalman), Poulsen \& Anderson, 1975, pp. 2075-2076, pl. 2, figs 1-9 [see remarks on Peratagnostus cicer]

Grandagnostus sp. Jago, 1976, pp. 141-142, pl. 22, figs 1-5

?Grandagnostus major Courtessole et al., 1988, p. 36, pl. 1, figs 6-11, ?pl. 8, fig. 7

Lectotype. Cephalon (State Museum of Natural History, Stockholm) selected and illustrated by Westergård (1946, p. 95 , pl. 15, fig. 6).

New material. More than 50 disarticulated specimens are in GGU 301312, 301313, and 313115.

Emended diagnosis. Cephalon subcircular to subpentagonal with broadly pointed anterior margin, width ranging from about 0.9 to 1.0 times that of length; convexity moderate to high. Pygidium subcircular to subpentagonal, width ranging from about 0.9 to 1.0 times that of length; convexity low. Border furrow of pygidium broad and shallow; border widens posteromedially on early holaspides, becoming narrow and more uniform on later holaspides. Dorsal exoskeleton finely punctate.

Remarks. From populations of $M$. glandiformis in Sweden, Westergård (1946, p. 96) noted that the ratio of length to width for both cephala and pygidia is greatly variable, even for specimens retaining original convexity. In dorsal view, the outlines of both shields also vary from subcircular (common in early holaspides) to subpentagonal (common in later holaspides). Many new specimens from Greenland possess the diagnostic characters of $M$. glandiformis and show similar ranges of morphological variation.

M. glandiformis is characterised by extreme effacement of dorsal features, including basal lobes, glabellar median node, and all but posterior vestiges of the cephalic border furrow. Jago (1976, p. 146) stated that some specimens possess vestigial basal lobes. On specimens I have observed, however, the basal lobes are expressed only as weak swellings if preservation is good. Some large cephala have a submarginal, ventral ridge formed by angular folding of the doublure. Where exposed by exfoliation, that ridge superficially resembles a border furrow (Fig. 33.7), and could be mistaken for such. Wellpreserved topotype specimens from Sweden, seemingly retaining original convexity, are illustrated here (Fig. 


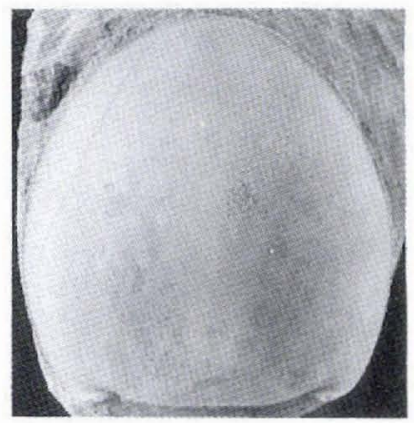

1a

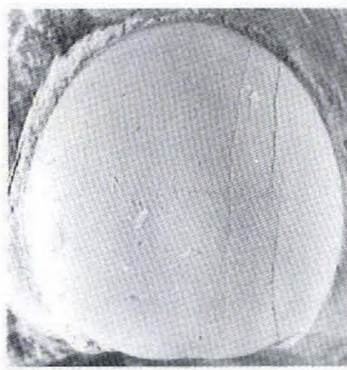

$2 \mathrm{a}$

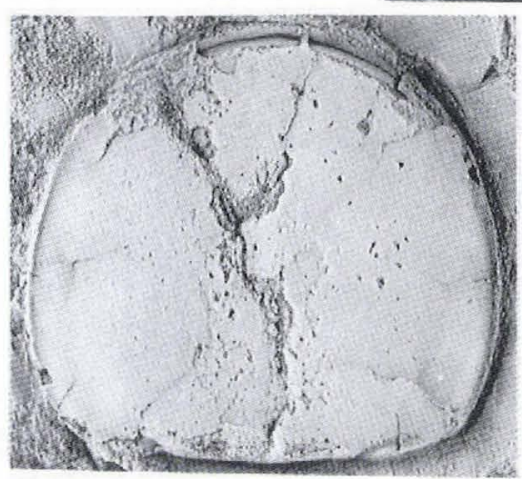

7

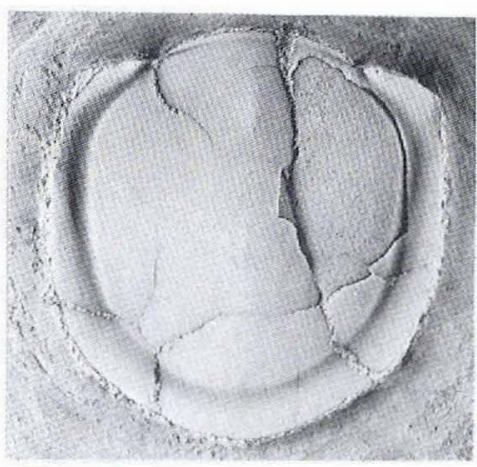

11

$2 b$

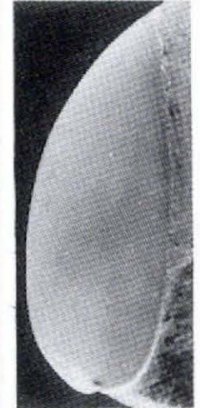

$1 b$

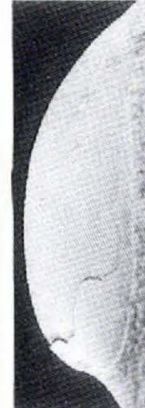

$8 b$
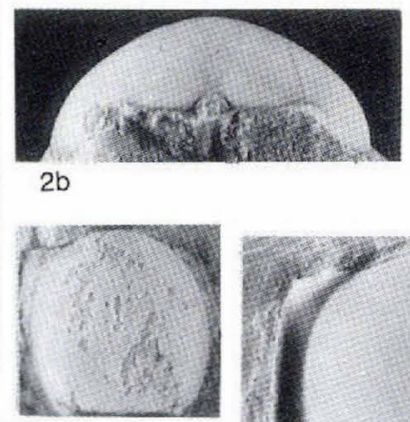

6
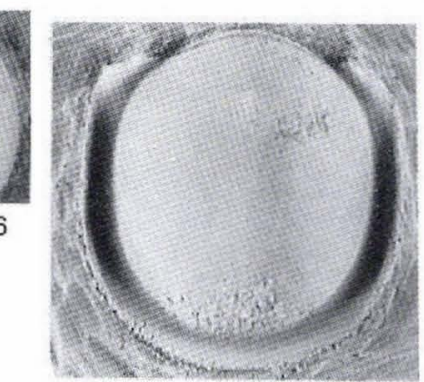

$3 a$

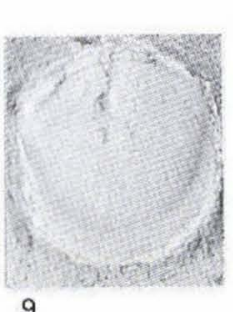

9

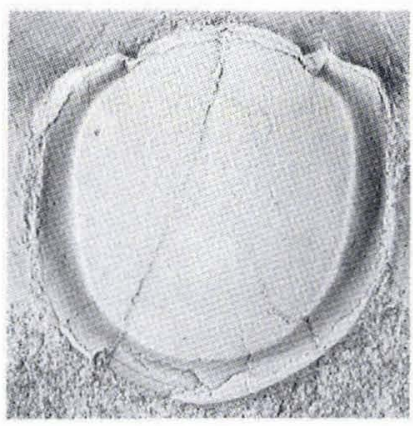

$12 a$

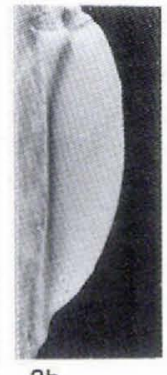

$3 b$
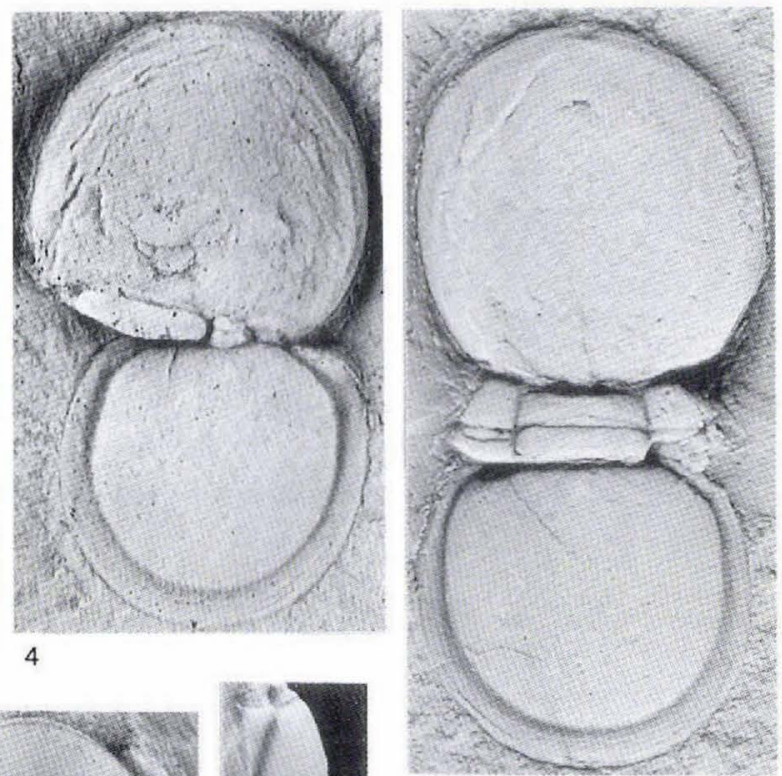

5

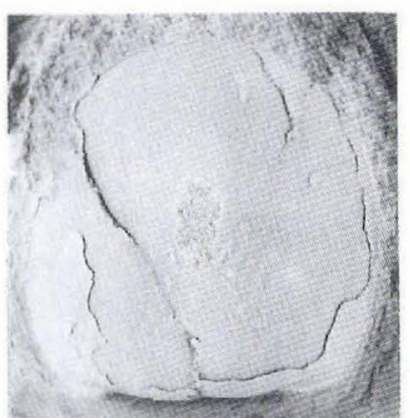

$8 a$

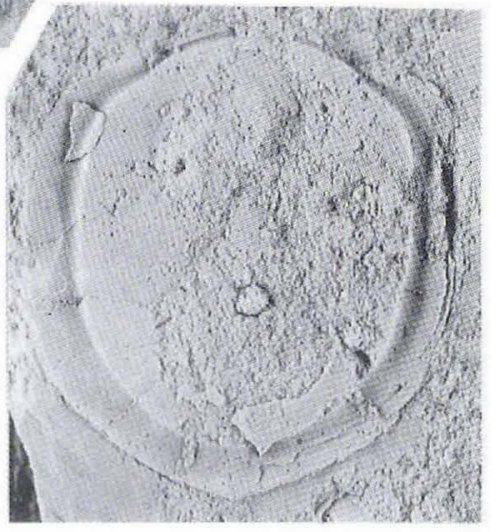

13

Fig. 33. Megagnostus glandiformis (Angelin) n. gen. 1-3, comparative topotype specimens from Andrarum Limestone, Sweden; 1a, b, cephalon in dorsal and lateral views, U.S. National Muscum of Natural History (USNM) no. 465529, × 3; 2a, b, cephalon in dorsal and rear views, USNM 465530, × 4; 3a, b, pygidium in dorsal and lateral views, USNM 465531, × 3. 4, 5, comparative specimens collected by William V. Murray from the Skeels Corners Formation, Vermont, showing wrinkles on cephala from compression in shale, USNM 465532 and $465533, \times 3$ and $\times 6.6$, small holaspid cephalon, MGUH 21.478 from GGU 313115, $\times 8.7$, large holaspid cephalon, partially flattened, MGUH 21.479 from GGU 301313, × 3. 8a, b, cephalon in dorsal and lateral views, MGUH 21.480 from GGU 301313, × 3. 9, 10, small holaspid pygidia from GGU 301313, MGUH 21.481 and 21.482, both $\times 8$. 11, pygidium, MGUH 21.483 from GGU 313115, × 4. 12a, b, pygidium in dorsal and lateral views, MGUH 21.484 from GGU $313115, \times 3.13$, large holaspid pygidium, MGUH 21.485 from GGU 301313, × 3. 
33.1-3) for comparison with new specimens from Greenland, which have been variably compressed in finegrained matrix.

The holotype of Grandagnostus vermontensis Howell, 1935a, which is the type species of Grandagnostus Howell, 1935a, is a poorly preserved, incomplete, smooth, probable cephalon that was recently discussed and reillustrated (Robison, 1988, p. 53, fig. 12.7). In the absence of definitive characters, I proposed that the name Grandagnostus be restricted to the holotype of $G$. vermontensis. My support for that proposal has not changed, and I here consider Grandagnostus to be an unrecognisable genus. Two specimens of $M$. glandiformis from a new locality in Vermont are illustrated here (Fig. 33.4, 5) for comparison with specimens from Sweden and Greenland. I have also examined other specimens that were originally illustrated as $G$. vermontensis, which are here reassigned to $M$. glandiformis (see synonymy for references).

In a subsequent diagnosis of Grandagnostus Shergold et al. $(1990$, p. 55) stated that the cephalic border is narrow or absent and the glabellar node is advanced. The holotype of the type species, however, shows no evidence of either a cephalic border or a glabellar node, although the configuration of adjacent matrix does superficially resemble an incomplete border.

Based on observed morphological variation in populations of M. glandiformis in Sweden and Greenland, I suggest that Grandagnostus longifrons Lermontova, 1940, Phalacroma maja Pokrovskaya, 1958, and Phalagnostus cuneatus Rosova, 1964 may be based on geographic variants of $M$. glandiformis in which length of the cephalon and angularity of its anterior margin are slightly accentuated. Without access to type collections, however, I reassign the specimens to $M$. glandiformis with question. At least two of the specimens illustrated as Phalacroma maja by Egorova, Pegel \& Chernysheva (in Egorova et al., 1982, pl. 47, figs 2, 3) appear to represent M. glandiformis.

$M$. glandiformis has the distinction of including the largest known specimens of the order Agnostida, which in size are substantially larger than average for the order. Westergaird (1946, p. 96) noted that the species is the largest agnostoid found in Scandinavia, and he reported the largest cephalon to be $16.0 \mathrm{~mm}$ long and $15.0 \mathrm{~mm}$ wide. A flattened cephalon in GGU 301313 (Fig. 33.7) is $14.2 \mathrm{~mm}$ long. The largest specimen from Greenland is a poorly preserved, incomplete pygidium in GGU 313115. It is $16.5 \mathrm{~mm}$ wide, but its length is indeterminate because of breakage. Although cracks indicate that its width may have been increased slightly by compression, it is relevant that the pygidium is smaller than the associated cephalon in this species (Fig. 33.4, 5; see also West- ergård, 1946, pl. 15, fig. 13a-d). Therefore, GGU 313115 may contain the largest observed agnostoid trilobite.

Occurrence. $M$. glandiformis is a widespread species, having been previously reported from Sweden, Norway, Denmark, Russia (Siberia), the United States (Vermont), Greenland (Nyeboe Land), Australia (Tasmania), and questionably from Canada (eastern Newfoundland), England, and France. The new specimens from Greenland are all from basal beds of the Kap Stanton Formation in Peary Land, and are from the lower Lejopyge laevigata Zone. Most reported occurrences of the species are from the $L$. laevigata Zone, however, it questionably ranges as low as the Ptychagnostus atavus Zone.

\section{Genus Peratagnostus Öpik, 1967}

Peratagnostus Öpik, 1967, pp. 86-87; Palmer, 1968, p. B26; Shergold, 1982, pp. 21-22; Shergold et al., 1990, pp. 43-44

Type species. Peratagnostus nobilis Öpik, 1967, pp. $87-90$.

Emended diagnosis. Cephalon mostly effaced, but retaining posterior border furrows, vestiges of basal furrows, and weak median node at about midlength; convexity moderate to high. Posterior vestige of glabella rounded. Thorax having transversely wide, effaced axial rings; pleural furrows weak. Pygidial ontogeny characterised by unusual, abrupt early holaspid metamorphosis during which border furrow first developed; subsequently, axial lobe increased in relative length and width as axial furrow became posteriorly effaced or entirely effaced; ring furrows undeveloped throughout ontogeny. Late holaspid pygidium highly convex; median node poorly defined, elongate. Articulating half ring of late holaspides variable in transverse width, being greater than half that of pygidium during early phylogeny and becoming less than half that of pygidium during later phylogeny. Spines absent.

Remarks. The concept of Peratagnostus has commonly been applied to species from only Upper Cambrian strata (e.g., Shergold et al. 1990, pp. 43-44). Based in part on character transformations during both ontogeny and inferred phylogeny, that concept is expanded here to include reassignment of Agnostus cicer Tullberg, 1880 and other species in Middle Cambrian strata.

The cephalon of Peratagnostus is characterised by advanced effacement of furrows, which may make the identification of disarticulated cephala difficult in collections containing other effaced genera. On some holaspid cephala the glabella may be indicated by a vestigial posterior swelling, and in some meraspid cephala the 
posteroglabella may be weakly outlined. In all but possibly one species, $P$. hillardensis Palmer, 1968, even the border furrow is effaced except for vestiges along the posterior cephalic margin. In discussing Grandagnostus falanensis (Westergård), which is herein reassigned to Peratagnostus, Rushton (1978, p. 257) noted that some internal moulds from England have lateral and frontal grooves that resemble a cephalic border furrow, but they represent the inner edge of the cephalic doublure. The single illustrated cephalon of $P$. hillardensis (Palmer, 1968, pl. 10, fig. 17) may also be an internal mould, and therefore warrants further investigation of its reputed marginal groove.

New specimens of $P$. cicer from North Greenland include distinctive juvenile pygidia (see Fig. 34.1,2) that closely resemble some pygidia previously assigned by Shergold (1982, pl. 6, figs 4-7) to P. nobilis Öpik, the type species of Peratagnostus. A significant character of these pygidia is a prominent, somewhat semicircular furrow on the dorsal surface. This, in reference to positions of the anterior border furrows, is identified as an axial furrow. Therefore, the largest of these pygidia are characterised by a well-defined, short, tumid axis with no ring furrows, and lateral and posterior parts of the border furrow are not evident.

In his study of $P$. nobilis, Shergold (1982, pp. 22-23) noted that pygidia with lengths less than $1.10 \mathrm{~mm}$ "are decidedly different from those with lengths greater than $1.50 \mathrm{~mm}$, and are considered to represent meraspid growth stages." He also noted that "no specimens with lengths between $1.10-1.50$ have been observed," and he concluded that if the smaller pygidia are to be regarded as $P$. nobilis, "then a substantial pygidial metamorphosis accompanies the change from meraspid to holaspid morphogenetic stages." A similar metamorphosis and a similar size gap between growth phases is indicated by specimens of $P$. cicer (see Fig. 34). Pygidia in the smaller growth phase range up to $1.1 \mathrm{~mm}$ in length and observed pygidia in the larger phase commence at $1.4 \mathrm{~mm}$ in length. Combined with general holaspid characters, I consider the distinctive juvenile morphology, evidence of dual growth phases, and the remarkably similar styles of metamorphosis to indicate a close taxonomic relationship between these two species, and to support their inclusion in the same genus.

The smallest pygidium of $P$. cicer in collection GGU 313115 from Greenland (see Fig. 34.1) has one axial ring, indicating that it represents degree 1 of the meraspid period (Robison, 1964, pp. 516-518). An apparent lack of axial rings on any of Shergold's (1982, pl. 6, figs 4-7) specimens of $P$. nobilis suggests that they are all holaspides. Therefore, the metamorphosis in both $P$. nobilis and $P$. cicer seems to have occurred during the early holaspid period. In some modern marine arthropods showing dual growth phases, the gap between them corresponds to onset of sexual maturity (Hartnoll, 1982). Although the same may be true for Peratagnostus, the rather abrupt change in form at very small body size may suggest some other cause. Changes in trophic resources, temperature, or mode of life are suggested as possible alternatives.

Although proportions of the pygidial axis are very similar in juveniles of $P$. cicer and $P$. nobilis (compare Fig. 34.1, 2 with Shergold, 1982, pl. 6, figs 4-7), they are quite different in large adults (compare Fig. $34.7,8$ with Öpik, 1967, text-fig. 18 and Palmer, 1968, pl. 10, fig. 24). $P$. cicer also retains vestiges of the axial furrow. Axial proportions of intermediate holaspid pygidia of $P$. cicer (see Fig. 34.3,4) accord with a possibility that the late holaspid axis of $P$. nobilis is paedomorphic with respect to that of $P$. cicer, its inferred ancestor. Thus, I attach trivial rather than generic significance to the late holaspid difference in axial proportions.

Juvenile specimens of Phalagnostus nudus (Beyrich, 1845), the type species of Phalagnostus Howell, 1955, are closely similar to those of Peratagnostus. In Phalagnostus, however, the distinctive juvenile characters are retained essentially unaltered into the late holaspid period (compare Šnajdr, 1958, pl. 5, figs 1-24). These persistent characters include a prominent semicircular axis and absence of cephalic and pygidial border furrows except for proximal vestiges along margins adjacent to the thorax. Based on shared characters, I suggest that Peratagnostus and Phalagnostus are closely related, and that Phalagnostus probably arose from Peratagnostus by paedomorphic retention of juvenile characters into the late holaspid period. Phalagnostus can be differentiated from Peratagnostus by the absence of a metamorphosis during ontogeny and by the related absence of two distinct growth phases. Late holaspid characters, or course, are quite different. As in modern marine arthropods (Williamson, 1982, p. 92), ontogeny within these genera seems to be "a reminder that adult and larval evolution can sometimes proceed independently."

Other species of Peratagnostus, as emended, are also present in Middle Cambrian strata. One of these is Ciceragnostus? falanensis Westergård, 1947. Rushton (1978, pp. 256-258) reassigned this species to Grandagnostus, and he suppressed Phalacroma bairdi Hutchinson (1962, pp. 90-91) as a junior synonym. Additional specimens were subsequently discussed and illustrated by Rushton (1983, p. 117, pl. 15, figs 2-5, 8, 9) from younger strata. As mentioned above in remarks on Megagnostus glandiformis, Grandagnostus is considered to be an unrecognisable genus. In degree of effacement, specimens of falanensis resemble those of both Megagnostus and Per- 
atagnostus. In convexity and mammiform transverse profile of its pygidium, however, they resemble specimens of only Peratagnostus. Therefore, falanensis is here reassigned to Peratagnostus, and I concur with Rushton that Phalacroma bairdi Hutchinson is a junior synonym. $P$. falanensis seems to be a direct descendent of $P$. cicer, from which it mainly differs by its axial furrow being more effaced on the late holaspid pygidium. $P$. cicer has an observed stratigraphic range in the Middle Cambrian from the Ptychagnostus atavus Zone into the Lejopyge laevigata Zone, and $P$. falanensis has a reported stratigraphic range from the uppermost Middle Cambrian (uppermost Lejopyge laevigata Zone) to the middle Upper Cambrian (upper Olenus Zone).

In addition to $P$. cicer (see synonymy below), other species of Peratagnostus have been reported from multiple localities in the upper Middle Cambrian of China. $P$. sinicus was named by Hsiang in Egorova et al. (1963) and has been further documented by Lu et al. (1965, p. 39, pl. 3, figs 23-25), Xiang et al. (1981, p. 118, pl. 7, figs 16, 17), and Xiang \& Zhang (1985, p. 70, pl. 14, figs 1-4). 'Peratagnostus exilis n. sp.' has been recorded on a biostratigraphic chart of taxa identified by Dong (1990, fig. 1) from a late Middle Cambrian section in western Hunan, China. Although the generic assignment of Dong's specimens may be correct, the new species name seems to be a nomen nudum. In an unpublished thesis by Song (1989, p. 46, pl. 3, figs 3-6), an undetermined species of Peratagnostus has been described and illustrated from the Lejopyge laevigata Zone of the same section in western Hunan.

One or more undetermined species of Peratagnostus may be represented by several distinctive juvenile specimens from the Lejopyge laevigata Zone. These include one pygidium from Sweden that Westergård (1946, p. 97, pl. 16, fig. 3) identified as Phalacroma sp., several pygidia from the Taconic sequence of New York that Rasetti (1967, pp. 38-39, pl. 10, figs 22-26) assigned as 'Agnostida, pygidium no. 1,' and two pygidia from Tasmania that Jago (1976, p. 168, pl. 26, fig. 15) assigned as 'Agnostid, gen. et sp. indet. no. 1.'

Several agnostoid species from Upper Cambrian strata have previously been assigned or reassigned to Peratagnostus. These have been reviewed in detail by Palmer (1968, p. B26) and Shergold (1982, pp. 21-22).

In posterior view, a mammiform profile may be characteristic of most or all late holaspid pygidia of $\mathrm{Per}$ atagnostus, as emended. Examples have been illustrated by Öpik (1967, pl. 52, fig. llb), Rushton (1978, pl. 24, figs 9, 11), and Song (1989, pl. 3, fig. 8b). Others are shown here (see Fig. 34.6c, 8a).

Peratagnostus, as emended, is geographically widespread in open-marine environments, and it has an ob- served stratigraphic range from the Ptychagnostus atavus Zone in the middle Middle Cambrian to the middle Upper Cambrian (for summary of Upper Cambrian occurrences, see Shergold et al., 1990, p. 44).

\section{Peratagnostus cicer (Tullberg, 1880)}

Fig. 34

Agnostus cicer Tullberg, 1880 , pp. 26-27, pl. 2, fig. 16a, b; Linnarsson, 1883, p. 32; Grönwall, 1902, p. 59

Agnostus cicer var. forfex Grönwall, 1902, pp. 59-60, pl. 1, fig. 5

Miagnostus cicer (Tullberg), Jaekel, 1909, p. 401

Ciceragnostus cicer (Tullberg), Westergård, 1946, pp. 90-91, pl. 14, figs 4-9; Pokrovskaya in Chernysheva, 1960, pl. 1, fig. 29; Hutchinson, 1962, p. 89 , pl. 10, figs 15,16 , pl. 11, figs 1 , 2; Öpik, 1967, p. 76; Yang, 1978, pp. 19-20, pl. 1, figs 8, 9; Yang, 1982, pl. 2, fig. 4; Egorova, Pegel \& Chernysheva in Egorova et al., 1982 (in part), p. 73, ?pl. 18, fig. 1, pl. 23, fig. 3; pl. 54, fig. 8; ?pl. 61, figs 3, 4 (not pl. 19, fig. 4)

Ciceragnostus cf. cicer (Tullberg), Westergård, 1946, pl. 16, fig. $6 \mathrm{a}, \mathrm{b}$

?'Agnostus' sp. No. 3 Westergård, 1946, p. 97, pl. 16, fig. 12a, b

New material. One complete specimen is in GGU 301313 (Fig. 34.7) and about 20 pygidia are in GGU 301312, 301313, and 313115. Several small cephala of this species are probably present in the same collections, but confident differentiation of these from associated small cephala of Megagnostus glandiformis and Toragnostus bituberculatus has not been possible, partly because of advanced effacement of the cephalon in all three species and partly because of inadequate preservation.

Emended diagnosis. Peratagnostus with cephalon mostly effaced and highly convex.

Pygidium variably effaced, with axial furrow progressively disappearing from posterior in early and middle holaspides. Late holaspid acrolobe tumid, mammiform in transverse profile. Axis commonly constricted at position of M2 in middle and late holaspides; separated from posterior border furrow in early holaspides, lengthening to reach furrow in middle holaspides; width less than half that of pygidium in early holaspides, increasing to more than half in late holaspides. Median axial node weak to well defined, usually elongate. Border furrow narrow in early holaspides, broadening and shallowing in later holaspides. Border convex in early holaspides, becoming flat or downsloping in later holaspides, especially toward posterior.

Remarks. Advanced effacement of some features, especially those of the cephalon, has hindered phylogenetic analysis of Agnostus cicer Tullberg, 1880, and its generic 


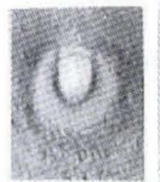

$1 a$

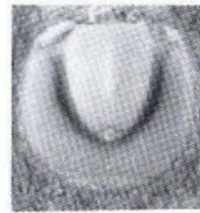

$2 b$

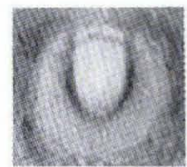

$1 b$

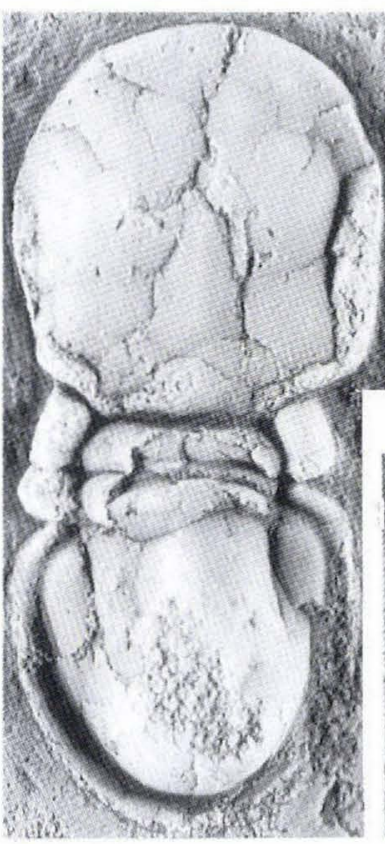

7

5

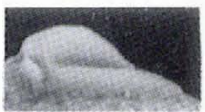

$2 c$

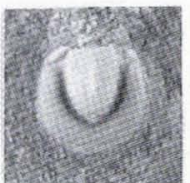

$2 a$

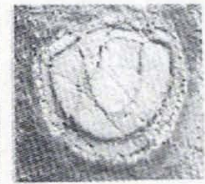

3

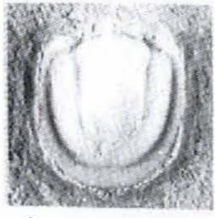

4

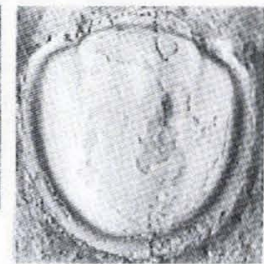

$6 b$

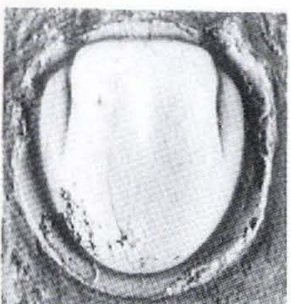

$6 a$
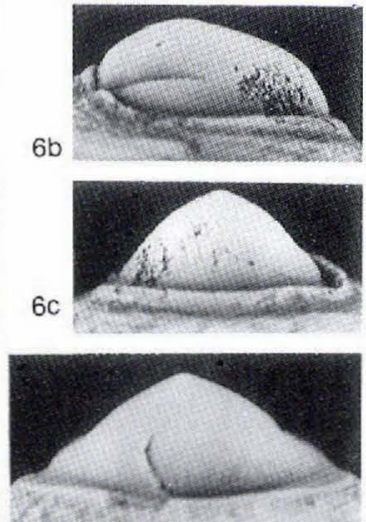

$8 a$

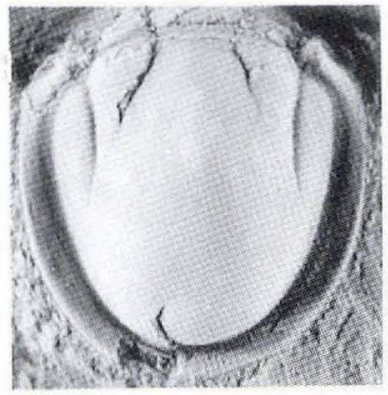

$8 b$
Fig. 34. Peratagnostus cicer (Tullberg). 1a, b. meraspid 1 pygidium, MGUH 21.486 from GGU 313115, × 10 and $\times 16.2 \mathrm{a}-\mathrm{c}$, early holaspid pygidium in dorsal (a, b) and lateral (c) views, MGUH 21.487 from GGU 313115, $\times 10$ (a) and $\times 16$ (b, c). 3, 4, small holaspid pygidia, MGUH 21.488 and 21.489 from GGU 313115 , both $\times 10$. 5, pygidium, MGUH 21.490 from GGU $301313, \times 10$. 6a-c, pygidium in dorsal, lateral and rear views, MGUH 21.491 from GGU 301313, × 10. 7, exoskeleton with cracked and flattened cephalon, MGUH 21.492 from GGU $301313, \times 8.8 \mathrm{a}, \mathrm{b}$, large pygidium in rear and dorsal views, with inner margin of doublure exposed where rear border is broken, MGUH 21.493 from GGU 301313, × 8 .

assignment has been problematic. Although $A$. cicer was reassigned to Ciceragnostus by Westergård (1946, pp.
90-91), it probably is not closely related to Agnostus barlowi Belt, 1868, the type species of Ciceragnostus (compare Morris \& Fortey, 1985, pl. 1, fig. 1), a species of Early Ordovician (Tremadocian) age. According to Shergold et al. (1990, p. 55), Ciceragnostus is characterised by a narrow cephalic border and probably is an effaced pseudagnostid. In comparison, A. cicer lacks all but posterior vestiges of a cephalic border and it shows no evidence of a pseudagnostid deuterolobe.

Reasons for reassignment of $A$. cicer to Peratagnostus are given above in remarks on the genus. This reassignment is based on both juvenile and adult characters, and especially those of the pygidium.

$P$. cicer, as emended, is an agnostoid species showing greater than usual ontogenetic variability in some features of the pygidium. Also, similar variability is present in populations from both Sweden and North Greenland. Rates of ontogenetic increase in length to width ratio were greater for the axis than for the entire pygidium (compare pygidia in Fig. 34). Westergård (1946, p. 90) noted that the axis of small pygidia (less than $1.5 \mathrm{~mm}$ in length) is usually outlined throughout, this being a juvenile feature persisting in rare adults, and a feature used by Grönwall (1902) to distinguish the variety forfex. Minor differences in length to width ratios of the cephalon and pygidium may result from taphonomic deformation and should be used with care in taxonomy of such species as $P$. cicer. If compression is extreme, posterolateral edges may collapse under the cephalon (e.g., Fig. 34.7), and may further affect the cephalic length to width ratio.

Occurrence. $P$. cicer, as emended, is known from Denmark, Sweden, the United States (Vermont), China (Hunan, Guizhou), Russia (Siberia), and Greenland. The new specimens are from basal beds of the Kap Stanton Formation in Peary Land, and are from the lower Lejopyge laevigata Zone. The occurrence in Vermont is a new report based on a single, articulated exoskeleton from the Skeels Corners Formation. The Vermont specimen was collected by W. V. Murray, and its description is being prepared for inclusion in a separate publication. The observed stratigraphic range of $P$. cicer is from the Ptychagnostus atavus Zone to the Lejopyge laevigata Zone in the Middle Cambrian.

\section{Genus Phalagnostus Howell, 1955}

Type species. Battus nudus Beyrich, 1845, p. 46.

Remarks. Based on the position of anterior border furrows, Rasetti (1967, pp. 38-39) concluded that the promi- 
nent subcircular furrow on the pygidium of Phalagnostus is an axial furrow rather than a border furrow. That interpretation has been supported by Poulsen (1969, p. 9), Jago (1976, p. 146), and Rushton (1978, pp. 255-256). If correct, Phalagnostus is an exceptional agnostoid in its lack of both lateral and posterior borders on the late holaspid pygidium.

\section{Phalagnostus ovalis (Illing, 1916)}

Fig. 35

Agnostus nudus (Beyrich) var. ovalis Illing, 1916, p. 415, pl. 31, figs 9,10

Phalacromina ovalis (Illing), Kobayashi, 1962, p. 29

Phalagnostus ovalis (Illing), Rushton, 1979, p. 60, fig. 9D;

Morris, 1988, pp. 174-175

not Phalagnostus ovalis Yang, 1982, pp. 302-303, pl. 2, fig. 1 Iregarded as secondary homonym, now Pseudophalacroma ovalis (Yang, 1982); 1985 International Code of Zoological Nomenclature, Article 57(c)]

New material. More than 20 specimens are in GGU 298970, 298975, 319789, and 319790 .

Emended diagnosis. Cephalon ovoid, moderately convex posteriorly. Axial furrow weakly defined posteriorly, disappearing anteriorly from near basal lobes. Border furrow weak posteriorly, absent laterally and anteriorly.

Pygidium ovoid, having low relief, except for axis. Axial furrow wide, moderately deep. Axis subcircular to subquadrate, lacking ring furrows; median node weak, carinate. Pleural fields unusually flat, slightly downsloping; confluent posteriorly; width more than doubling

Fig. 35. Phalagnostus ovalis (Illing). All specimens from GGU 298970. 1, partly exfoliated cephalon in dorsal and lateral views, MGUH 21.494, $\times$ 8. 2, damaged cephalon, MGUH $21.495, \times 8.3,6$, smaller pygidia, MGUH 21.496 and 21.497 , both $\times$ 10. 4 , large pygidium in dorsal and lateral views, MGUH 21.498, × 8. 5 , damaged pygidium, MGUH 21.499 , $\times 8$. from anterior to posterior. Border furrow weak anteriorly, absent laterally and posteriorly.

Remarks. $P$. ovalis was previously known from only a single enrolled specimen from England, which Rushton (1979) designated as the lectotype. New specimens from Greenland are closely similar, but the pygidial axis on larger holaspides is slightly more elongate. The axis appears to have become more elongate during ontogeny, so I do not regard that difference to be of taxonomic importance.

This species is the type of Phalacromina Kobayashi (1962, p. 29), which Rushton (1978, p. 256) suppressed as a subjective synonym of Phalagnostus. I concur with that action.

Occurrence. $P$. ovalis has been previously reported from horizon C2 in the Abbey Shales of the English Midlands. In North Greenland it is in collections from the upper Henson Gletscher Formation and from basal beds of the Kap Stanton Formation. Observed specimens from both England and Greenland are from the Ptychagnostus atavus Zone.

\section{Genus Schismagnostus n. gen.}

Etymology. Greek schisma, cleft or split, plus Agnostus; referring to the extraordinarily long frontal sulcus of the juvenile glabella.

Type species. Schismagnostus plicatus n. $\mathrm{sp}$.

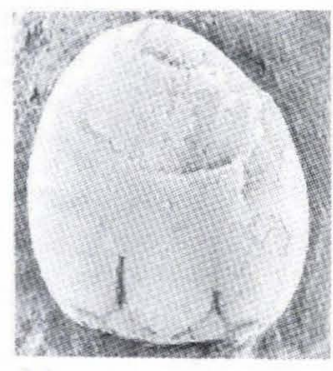

$1 \mathrm{a}$

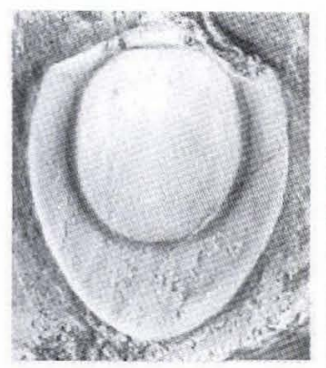

$4 b$

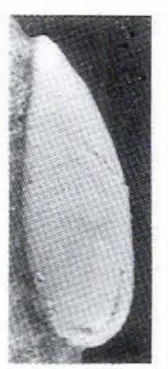

$1 \mathrm{~b}$

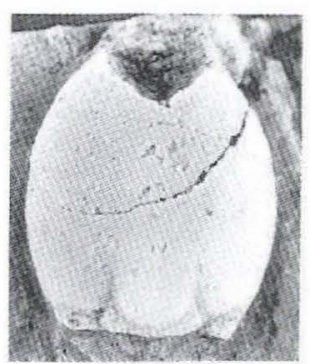

2

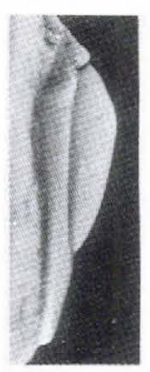

$4 \mathrm{a}$

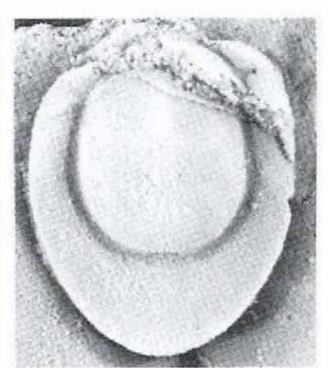

5

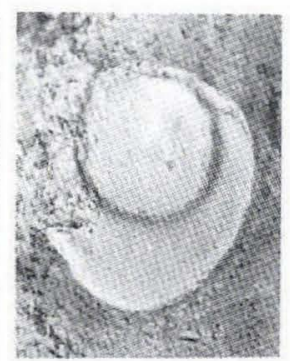

3

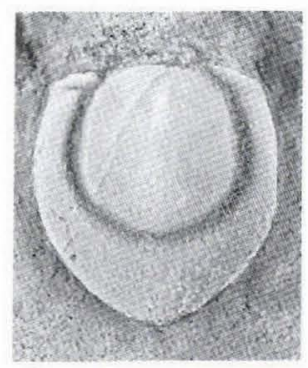

6 
Diagnosis. Cephalon subquadrate. Glabella subcylindrical, bipartite with F3 bowed rearward; F1 and F2 prominent. Basal lobes simple to slightly elongate. Genae having abundant scrobicular grooves and pits; separated by preglabellar median depression, which may contain finer scrobiculae. Border narrow to moderately wide. Glabella of early instars having extraordinarily long frontal sulcus, extending rearward to about level of $\mathbf{F} 2$.

Thorax not known.

Pygidium subquadrate with pair of posterolateral border spines. Axis variable in length, subcylindrical with slight constriction at M2 and pointed posterior end; F1 weak, slightly bowed forward; F2 weak, straight to slightly bowed forward; median tubercle ovate, moderately large, confined to M2, and not interrupting F2. Posteroaxis slightly ogival, having shallow transverse sulcus with median node. Postaxial median furrow present and deep if axis is reduced in length. Border furrow moderately wide to wide.

Remarks. Schismagnostus is characterised by greater morphological change in the cephalon than is usual in other agnostoid genera during holaspid ontogeny. Beginning at least with early holaspid specimens, the cephalon already has well-developed genal scrobiculae, the anteroglabella is unusually small, and a deep frontal sulcus penetrates the anteroglabella and continues well back into the posteroglabella. To my knowledge, this is the only agnostoid with a frontal sulcus extending into the posteroglabella. On later holaspid specimens the frontal sulcus is entirely effaced, which seems to have occurred abruptly, perhaps between instars. At the same time, the anteroglabella was substantially enlarged. In the preceding diagnosis, however, late holaspid characters are emphasised because descriptions of agnostoid genera have been generally based on characters of that ontogenetic stage.

Late holaspid specimens of Schismagnostus resemble those of some species of Tomagnostus in such characters as pattern of genal scrobiculae and presence of a transverse sulcus on the posteroaxis. Representative specimens of the type species of each genus, however, differ in all holaspid instar stages (compare Figs $30 \& 36$ ), although less significantly in later ones. The early holaspid cephalon of $S$. plicatus is characterised by a relatively small anteroglabella and an extraordinarily long frontal sulcus, which penetrates to about the level of the F2 (see Fig. 36.1-6). Early holaspid instars of Tomagnostus fissus also have a frontal sulcus, but the anteroglabella is relatively large, its frontal sulcus is short, and the front part of its posteroglabella is tumid and carinate (see Fig. 30.6) rather than sulcate. Following a seemingly abrupt ontogenetic transformation, the frontal sulcus is entirely effaced from the middle holaspid cephalon of $S$. plicatus, and its anteroglabella is much enlarged in relative size (see Fig. $36.7 \mathrm{a}-\mathrm{c})$. In comparison, ontogenetic changes in proportions of the anteroglabella and length of the frontal sulcus are minor in T. fissus. These and other differences in axial structure are considered to have important taxonomic significance, and are the basis for distinguishing the new genus Schismagnostus. Based on all characters, but especially those of early ontogenetic stages, Schismagnostus does not seem to be closely related to any described agnostoid genus, and its phyletic origin is obscure.

Two species are here assigned or reassigned to Schismagnostus. One is the type species, S. plicatus n. sp., which is known from only the Ptychagnostus gibbus Zone of North Greenland. The other is S. clarus (Pokrovskaya \& Egorova in Egorova et al., 1982, p. 60, text-fig. 2, pl. 14, figs 7, 8), which has a reported range in Siberia corresponding to the interval from the lower Ptychagnostus punctuosus Zone to the lower Lejopyge laevigata Zone.

\section{Schismagnostus plicatus $\mathbf{n}$. sp.}

Fig. 36

Etymology. Greek plicatus, folded; referring to the strong genal scrobiculae, even on the juvenile cephalon.

Holotype. Cephalon (Fig. 36.9a, b), MGUH 21.508 from GGU 298970.

Material. Nine cephala and 2 pygidia are in GGU 298970.

Diagnosis. Cephalon having extraordinarily long frontal sulcus on glabella of early holaspides, but effaced on later holaspides. Basal lobes exceptionally short. Pygidium with short axis, pleural fields divided by deep postaxial median furrow, and pair of large border spines.

Description. Cephalon ovate to subquadrate; anterior margin broadly rounded to nearly straight, lateral sides tapering rearward. Glabella bipartite with $\mathrm{F} 3$ bowed rearward. Frontal sulcus extraordinarily long in early holaspides, extending rearward to about level of F2; seemingly becoming abruptly effaced between early and middle holaspid stages. Anteroglabella short and laterally constricted in early holaspides, width being about half that of postjacent segment; abruptly increasing in relative size as frontal sulcus is effaced. Posteroglabella elongate rectangular; F2 weak to moderately well defined, F1 well defined; M3 laterally tumid, divided by frontal sulcus in early holaspides and by shallow depression in later holaspides; M2 may be slightly constricted and less tumid 
than M1 and M3 in early holaspides; M1 subcircular. Median glabellar node weak; shifting from front of M1 in early holaspides to middle M2 in later holaspides. Basal lobes extraordinarily reduced in length, being only slightly longer than exsaggital width of posterior border in early holaspides, gradually enlarging in later holaspides, but still exceptionally short in late holaspid stage. Genae having prominent scrobiculae throughout holaspid ontogeny; rugae becoming more complex during ontogeny, developing as many as five orders of branching in late holaspides. Border furrow and border both narrow.

Thorax not known.

Pygidium subquadrate with lateral sides tapering forward. Axis short, well separated from posterior border furrow; F1 shallow, bowed anteriorly; F2 shallow, straight or bowed forward; median tubercle on M2 ovate, moderately large, and most tumid toward rear; posteroaxis slightly ogival with shallow transverse sulcus containing median node surrounded by two pairs of tiny pits. Pleural fields having rough surface; divided by deep, median, postaxial furrow. Border furrow moderately wide. Border moderately wide posteriorly, narrowing anterolaterally; expanding posterolaterally into pair of large, broad-based spines.

Remarks. S. plicatus appears to be closely related to Tomagnostus clarus Egorova \& Pokrovskaya (in Egorova et al., 1982, p. 60, pl. 14, figs 7,8), which is here reassigned to Schismagnostus. Late holaspid specimens of $S$. plicatus can easily be distinguished from those of $S$. clarus, however, by their distinctly shorter basal lobes, a shorter pygidial axis, presence of a postaxial median furrow, narrower pygidial border furrow, and larger pygidial border spines. Early holaspid specimens have not been described or illustrated for $S$. clarus, and therefore cannot be compared with those of S. plicatus.

Occurrence. All specimens of $S$. plicatus are from the

Fig. 36. Schismagnostus plicatus n. gen. \& n. sp. All specimens are from GGU 298970. 1-3, late meraspid or early holaspid cephala, MGUH 21.500-21.502, all x 10. 4a, b, cephalon, probably an early holaspid, in lateral and dorsal views, MGUH $21.503, \times 10.5,6$, cephala, probably early holaspides, MGUH 21.504 and 21.505 , both $\times 10$. 7a-c, middle holaspid cephalon in stereographic (a, b) and lateral (c) views, MGUH 21.506, × 10. 8 , incomplete middle holaspid cephalon, MGUH 21.507, $\times 10$. $9 \mathrm{a}, \mathrm{b}$, holotype cephalon in lateral and dorsal views, MGUH $21.508, \times 8.10 \mathrm{a}, \mathrm{b}$, pygidium in dorsal and lateral views, MGUH 21.509, ×8. $11 \mathrm{a}-\mathrm{c}$, pygidium in lateral and dorsal views (b, c) and latex cast showing more complete right marginal spine (a), MGUH $21.510, \times 8$. middle Henson Gletscher Formation of Nyeboe Land, and are from the Ptychagnostus gibbus Zone.

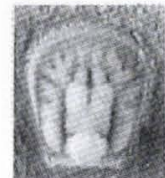

1

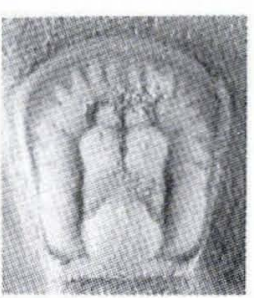

$4 b$

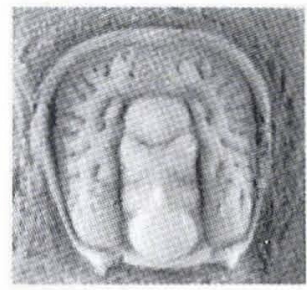

$7 a$

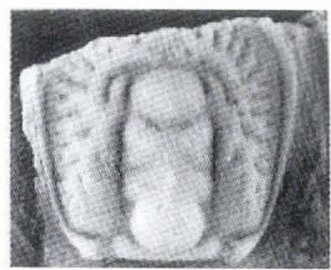

8

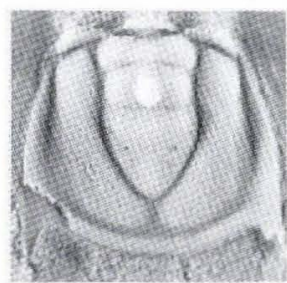

$10 \mathrm{a}$

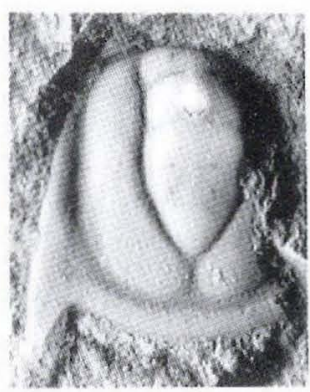

$11 \mathrm{a}$

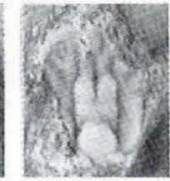

3

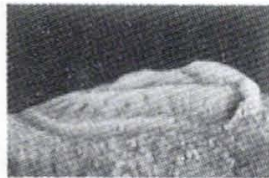

$4 a$

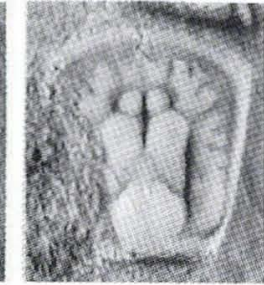

6

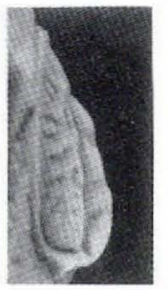

7c

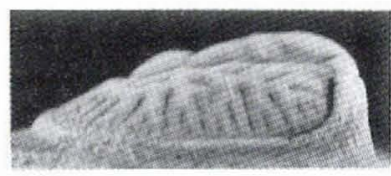

$9 a$

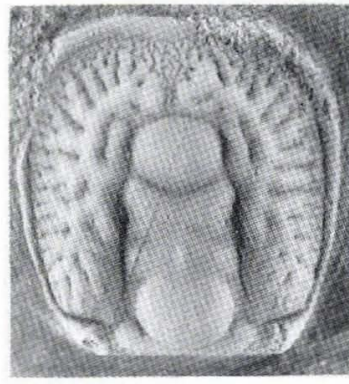

$9 b$

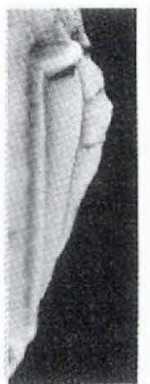

$11 b$

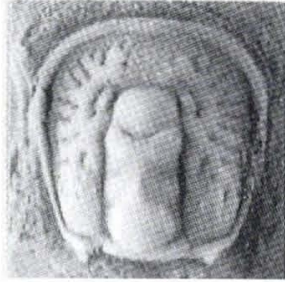

$7 \mathrm{~b}$

110

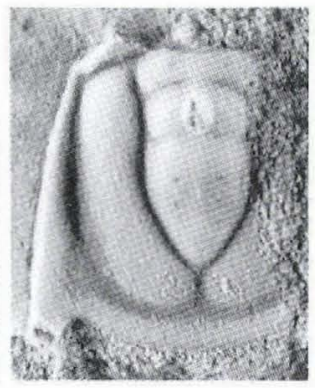



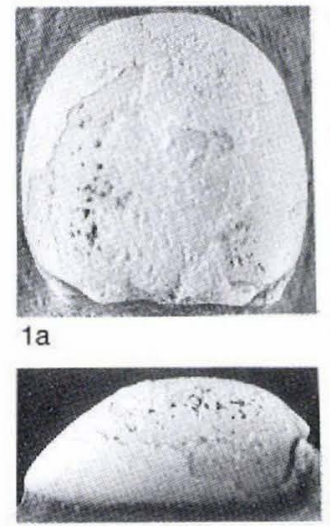

$1 \mathrm{~b}$

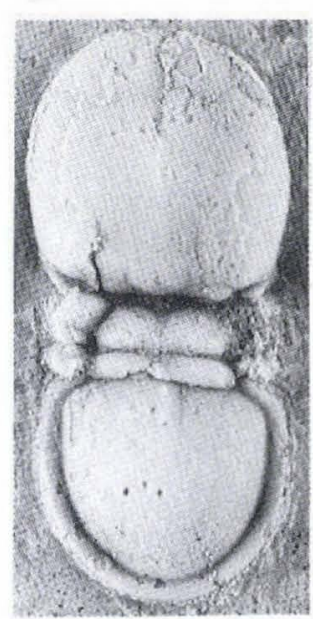

4

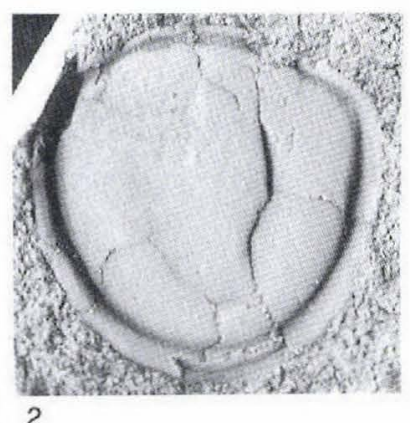

2

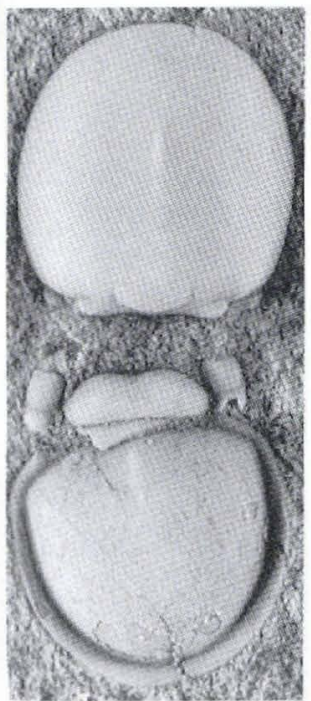

$5 a$

$5 b$

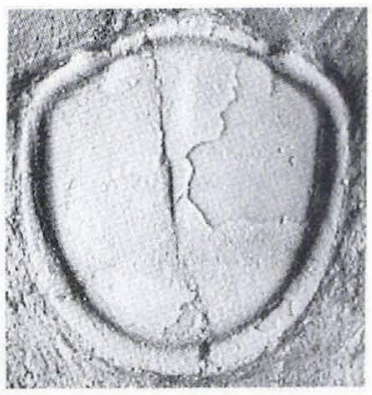

3

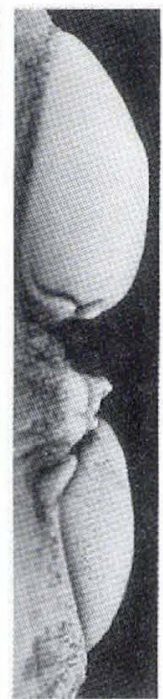

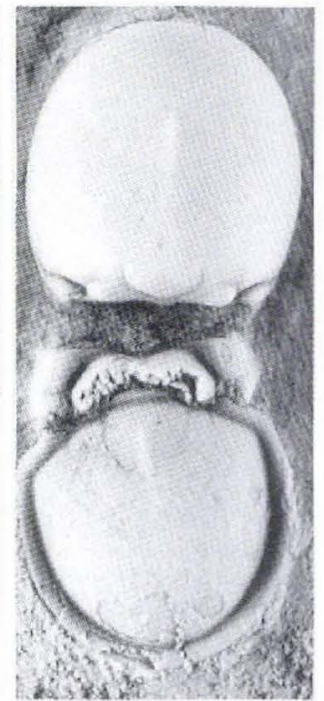

$5 c$
Fig. 37. Toragnostus bituberculatus (Angelin). la, b, cephalon in dorsal and lateral views, MGUH 21.511 from GGU 313115, × 8.2, latex cast of pygidium with doublure exposed where posterior border is broken, MGUH 21.512 from GGU $313115, \times 8.3$, flattened pygidium, MGUH 21.513 from GGU 301312 , × 8.4, dorsal exoskeleton, MGUH 21.514 from GGU $301313, \times 10.5 \mathrm{a}-\mathrm{c}$, dorsal exoskeleton, MGUH 21.515 from GGU 301313 , all $\times 10$; a, latex cast showing nearly complete anterior thoracic segment; b, c, specimen in lateral and dorsal views.

\section{Genus Toragnostus Robison, 1988}

Type species. Agnostus bituberculatus Angelin, 1851, p. 6.

Remarks. The generic diagnosis of Robison (1988, pp. 52-53) is followed here (see also Shergold et al., 1990, p. 57).

\section{Toragnostus bituberculatus (Angelin, 1851)} Fig. 37

New material. More than 70 specimens are in GGU 301312 (rare), 301313 (abundant), and 313115 (common).

Remarks. Complete specimens of $T$. bituberculatus in GGU 301313 (Fig. 37.4, 5) are the first to be illustrated for the species. These show the anterior thoracic segment to be longer sagittally than the posterior thoracic segment, and the axial ring of each thoracic segment is smooth. All new material, including numerous disarticulated cephala and pygidia, agrees well with previous descriptions of the species (for synonymy, see Robison, 1988 , p. 53).

Lu \& Lin (1989, pp. 113-114, 230, pl. 13, figs 7-10) named a new species Phalagnostus carinatus that appears to be conspecific with $T$. bituberculatus, but it is said to differ by having a longer and more posterior median carina on the cephalon as well as slight differences in the vestigial axial furrow and uniformity in width of the border on the pygidium. The three illustrated cephala of the Chinese species are not well preserved and the nature of the median carina is not clear from the photographs. Characters of the single illustrated pygidium appear to be within the range of variation observed elsewhere in populations of $T$. bituberculatus. Thus, I consider $P$. carinatus Lu \& Lin to be a questionable junior synonym of $T$. bituberculatus.

Occurrence. T. bituberculatus is geographically widespread in the Lejopyge laevigata Zone. Rare specimens have been previously documented from the upper $L$. 
laevigata Zone in the lower Holm Dal Formation of Peary Land, North Greenland (Robison, 1988, p. 53, fig. 12.4-6). The new specimens are from the lower $L$. laevigata Zone in basal beds of the Kap Stanton Formation of Peary Land.

\section{Genus and species undetermined 1}

Fig. 9.1a, b

Remarks. A single pygidium in GGU 298970 from the Ptychagnostus gibbus Zone of the middle Henson Gletscher Formation, Nyeboe Land, is unassigned to genus and species. It is characterised by a bowed articulating furrow, fully developed ring furrows (F1 \& F2), a carinate median tubercle, a tumid and ogival posteroaxis, a short postaxial median furrow, a wide border furrow, and a pair of border spines. It resembles pygidia of Peronopsis bulkurensis, discussed above, but differs by having a bowed rather than straight articulating furrow and better developed ring furrows. It resembles Schismagnostus plicatus $\mathrm{n}$. gen. \& n. sp., described above, in development of ring furrows, but its posteroaxis is more tumid, it lacks a transverse sulcus, and its border spines are less robust. It also resembles pygidia of Peronopsis segmenta Robison, 1964 (compare Robison, 1982, pl. 6, figs 3,4 ), but the F2 is not effaced.

\section{Genus and species undetermined 2}

Fig. 9.2, 3

Material. Two cephala are in GGU 298969 and one cephalon is in GGU 298970.

Remarks. Three small cephala of this taxon are characterised by a long, narrow, bipartite glabella with an F3 that is bowed slightly rearward. The glabella also has a short frontal sulcus. The posteroglabella is unusually long and its median node is posterior from the midpoint. Basal lobes are simple and do not indent the glabella, genae are smooth, and the border is moderately wide anteriorly and tapers posteriorly. Considering all characters, these cephala resemble those of Tomagnostus but the border is wider anteriorly and of less uniform width, and the basal lobes do not indent the glabella.

Occurrence. This taxon is from the upper Henson Gletscher Formation in Nyeboe Land, being present in both the Ptychagnostus gibbus and Ptychagnostus atavus zones.

Acknowledgements. Fossils used in this study were mostly collected by John S. Peel (now Uppsala University), who arranged for their loan from the Geological Survey of Greenland, and who provided valuable information, advice, and encouragement. The manuscript has benefitted from constructive reviews by L. E. Babcock, J. B. Jago, A. R. Palmer, and A. W. A. Rushton. Research support was provided by U.S. National Science Foundation grant EAR-8720333.

\section{References}

Ahlberg, P. 1988: A revision of the Ordovician agnostid trilobite Leiagnostus Jaekel 1909. Geol. Fören. Stockholm Förh. 110, 363-370.

Ahlberg, P. 1992: Agnostid trilobites from the Lower Ordovician of southern Sweden. Trans. R. Soc. Edinburgh 83, 539-570.

Angelin, N. P. 1851: Palaeontologia Suecica, pars I: Iconographia crustaceorum formationis transitionis, $24 \mathrm{pp}$. Lund: Weigel.

Babcock, L. E. 1994a: Systematics and phylogenetics of polymeroid trilobites from the Henson Gletscher and Kap Stanton formations (Middle Cambrian), North Greenland. Bull. Grønlands geol. Unders. 169 (this volume).

Babcock, L. E. 1994b: Biogeography and biofacies patterns of the Middle Cambrian polymeroid trilobites from North Greenland: palaeogeographic and palaeo-oceanographic implications. Bull. Gronlands geol. Unders. 169 (this volume).

Barrande, J. 1846: Notice préliminaire sur le Systême silurien et les Trilobites de Bohême, 96 pp. Leipzig: Hirschfeld.

Belt, T. 1868: On the 'Lingula Flags,' or 'Festiniog Group' of the Dolgelly district, part III. Geol. Mag. 5, 5-11.

Bergeron, J. 1889: Étude géologique du Massif ancien situé au sud du plateau central. Annales Sci. Géol., Paris 22, 361 pp.

Beyrich, E. 1845: Ueber einige böhmische Trilobiten, $47 \mathrm{pp}$. Berlin: G. Reimer.

Borovikov, L. T. \& Kryskov, L. N. 1963: [Cambrian deposits of the Kendyktas Mountains (south Kazakhstan)]. Trudy Vses. Nauch.-Issled. geol. Inst (VSEGEI), 1, N S 94 [in Russian; not seen, cited by Öpik 1967].

Brøgger, W. C. 1878: Om paradoxideskifrene ved Krekling. $N y t$ Mag. Naturvid. 24, 18-88.

Brongniart, A. 1822: Les Trilobites. In Brongniart, A. \& Desmarest, A.-G., Histoire naturelle des crustacés fossiles, 1-66. Paris: F.-G. Levrault.

Chernysheva, N. E. (ed.) 1960: [Principles of paleontology; arthropods, trilobites and crustaceans.] Moscow: Gosudar. Nauchno-Tekh. Izd. Lit. Geol. Okhr. Nedr., 515 pp. (in Russian).

Courtessole, R. 1973: Le Cambrien moyen de la Montagne Noire; biostratigraphie, 248 pp. Toulouse: Lab. géol CEARN, Fac. Sci.

Courtessole, R., Pillet, J. \& Viscaino, D. 1988: Stratigraphie et paléontologie du Cambrien moyen greseux de la Montagne Noire (versant meridional). Mém. Soc. d'Etudes Scientifiques de l'Aude, Carcassonne, France, 55 pp.

Daily, B. \& Jago, J. B. 1975: The trilobite Lejopyge Hawle \& Corda and the Middle - Upper Cambrian boundary. Palaeontology 18, 527-550.

Dalman, J. W. 1828: Nya Svenska Paleader. Kongl. Sv. Vet. 
Acad., Årsberättelser om nyare zoologiska arbeten och upptäckter, 138 pp.

Dong Xiping 1990: A potential candidate for the Middle Upper Cambrian boundary stratotype - an introduction to the Paibi section in Huayuan, Hunan. Acta Geol. Sinica 3, 309327.

Egorova, L. I., Xiang Liwen, Lee Shangi, Nan Ronshan \& Kuo Zhengming 1963: [Cambrian trilobite fauna from Kwenchow and western Hunan.] Stratigr. Palaeont. 3(1), 1-117. China Industrial Press, Beijing. (In Chinese.)

Egorova, L. I., Shabanov, Y. Y., Rozanov, A. Y., Savitsky, V. E., Chernysheva, N. E. \& Shishkin, B. B. 1976: [Elansky and Kuonamsky facies stratotypes of the lower boundary of the Middle Cambrian in Siberia.] Trudy Sibir. Nauchno-Issled. Inst. Geol. Geofiz. Miner. Syr. 211, 1-228 (in Russian).

Egorova, L. I., Shabanov, Y. Y., Pegel, T. V., Savitsky, V. E., Suchov, S. S. \& Chernysheva, N. E. 1982: [Maya Stage of the type locality (Middle Cambrian of Siberian platform)]. Trudy Akad. Nauk SSSR, Minist. Geol., Mezhbedom. Stratigr. Kom. SSSR 8, 1-146 (in Russian).

Ergaliev, G. K. 1980: [Middle and Upper Cambrian trilobites of the Lesser Karatau Range.] Akad. Nauk Kazakh. SSR, Inst. Geol., Alma-Ata, 210 pp. (in Russian).

Etheridge, R., Jr. 1902: Official contributions to the palaeontology of South Australia, no. 13; evidence of further Cambrian trilobites. S. Aust. Parliamentary Pap., 3-4.

Fatka, O. \& Kordule, V. 1992: New fossil sites in the Jince Formation (Middle Cambrian, Bohemia). Věstnik Českého geol. úst. 67, 47-60.

Fatka, O., Kordule, V. \& Šnajdr, M. 1981: New Middle Cambrian trilobites from the Barrandian. Věstnik Ústřed. úst. geol. 56, 367-370.

Fortey, R. A. 1980: The Ordovician trilobites of Spitsbergen III: remaining trilobites of the Valhallfonna Formation. Norsk Polarinstitutt Skr. 171, 163 pp.

Gil Cid, M. D. 1981: Los trilobites agnóstidos del Cámbrico Inferior y Medio de España. Bol. Geol. Miner. 92(2), 21--36.

Grönwall, K. A. 1902: Bornholms Paradoxideslag og deres fauna. Danm. geol. Unders. (Ser. 2) 13, $230 \mathrm{pp}$.

Gunther, L. F. \& Gunther, V. G. 1981. Some Middle Cambrian fossils of Utah. Brigham Young Univ. Geol. Studies 28(1), 81 pp.

Harrington, H. J. 1938: Sobre las faunas del Ordoviciano Inferior del norte Argentino. Revta Mus. La Plata, N S 1, 109-289.

Harrington, H. J. et al. 1959: Trilobita. In Moore, R. C. (ed.) Treatise on invertebrate paleontology, O, Arthropoda 1, O38-0560. Lawrence, Kansas: Geol. Soc. Am., Kansas Univ. Press.

Hartnoll, R. G. 1982: Growth. In Abele, L. G. (ed.) The biology of Crustacea, volume 2, embryology, morphology, and genetics, 111-196. New York: Academic Press.

Hawle, I. \& Corda, A. J. C. 1847: Prodrom einer Monographie der böhmischen Trilobiten. Abh. K. böhm. Ges. Wiss. 5, 176 pp.

Henningsmoen, G. 1958: The Upper Cambrian faunas of Norway. Norsk geol. Tidsskr. 38, 179-196.
Hicks, H. 1872: On some undescribed fossils from the Menevian Group. $Q$. $J l$ geol. Soc. Lond. 28, 173-185.

Holm, G. \& Westergård, A. H. 1930: A Middle Cambrian fauna from Bennett Island. Mem. Acad. Sci. l'URSS 21(8), 1-25.

Howell, B. F. 1925: The faunas of the Cambrian Paradoxides beds at Manuels, Newfoundland. Bull. Am. Paleont. 11(43), 140 pp.

Howell, B. F. 1935a: New Cambrian agnostian trilobites from Vermont. J. Paleont. 9, 218-221.

Howell, B. F. 1935b: Cambrian and Ordovician trilobites from Herault, southern France. J. Paleont. 9, 222-238.

Howell, B. F. 1935c: Some New Brunswick Cambrian agnostians. Bull. Wagner Free Inst. Sci. 10(2), 13-16.

Howell, B. F. 1937: Cambrian Centropleura vermontensis fauna of northwestern Vermont. Bull. geol. Soc. Am. 48, 11471210.

Howell, B. F. 1955: Phalagnostus, new genus for trilobite Battus nudus Beyrich. J. Paleont. 29, 925-926.

Hunt, A. S. 1966: Submarginal suture and ventral plate of an agnostid trilobite. J. Paleont. 40, 1238-1240.

Hutchinson, R. D. 1962: Cambrian stratigraphy and trilobite faunas of southeastern Newfoundland. Bull. geol. Surv. Can. 88, 156 pp.

Illing, V. C. 1916 [dated 1915]: Paradoxidian fauna of the Stokingford Shales. Q. Il geol. Soc. Lond. 71, 386-450.

Ineson, J. R. 1988: Lithostratigraphy and depositional setting of the Holm Dal Formation (Middle Cambrian), central North Greenland. Meddr Grønland Geosci. 20, 9-21.

Ineson, J. R., Surlyk, F., Higgins, A. K. \& Peel, J. S. 1994: Slope apron and deep shelf sediments of the Brønlund Fjord and Tavsens Iskappe Groups (Lower Cambrian - Lower Ordovician), North Greenland: stratigraphy, facies and depositional setting. Bull. Gronnlands geol. Unders. 169 (this volume).

Jaekel, O. 1909: Über die Agnostiden. Z. dt. geol. Ges. 61, 380-401.

Jago, J. B. 1976: Late Middle Cambrian agnostid trilobites from north-western Tasmania. Palaeontology 19, 133-172.

Jago, J. B. \& Daily, B. 1974: The trilobite Clavagnostus Howell from the Cambrian of Tasmania. Palaeontology 17, 95-109.

Jell, P. A. \& Robison, R. A. 1978: Revision of a late Middle Cambrian trilobite faunule from northwestern Queensland. Paleont. Contr. Univ. Kansas Pap. 90, 21 pp.

Khajrullina [Hairullina], T. I. 1970: [Trilobites of the Maiskov Stage of the Turkestan Mountains.] In Shayukuboe, T. S. (ed.) [Biostratigraphy of the sedimentary area of Uzbekistan] 9, 5-53. Leningrad: Nedra (in Russian).

Khajrullina [Hairullina], T. I. 1973: [Biostratigraphy and trilobites of the Maiskov Stage, Middle Cambrian of the Turkestan Mountains]. Sred-aziat. nauchno-issled. Inst. Geol. Miner. Syr. Tashkent: FAN, 112 pp. (in Russian).

Khalfin, L. L. (ed.) 1960: [Paleozoic biostratigraphy of the Sayan-Altai mountain region, I; Lower Paleozoic]. Trudy Sibir. Nauchno-Issled. Inst. Geol. Geofiz. Miner. Syr. 19, $1-498$ (in Russian).

Kindle, C. H. 1982: The C. H. Kindle collection: Middle Cambrian to Lower Ordovician trilobites from the Cow Head 
Group, western Newfoundland. Pap. geol. Surv. Can. 82-1C, $1-17$.

Kobayashi, T. 1937: The Cambro-Ordovician shelly faunas of South America. J. Fac. Sci., Tokyo Univ. 4(4), 369-533.

Kobayashi, T. 1938: Upper Cambrian fossils from British Columbia with a discussion on the isolated occurrence of the so-called Olenus beds of Mt. Jubilee. Japanese J. Geol. Geogr. 15, 149-192.

Kobayashi, T. 1939: On the agnostids (Part 1). J. Fac. Sci., Tokyo Univ. 5(5), 69-198.

Kobayashi, T. 1962: The Cambro-Ordovician formations and faunas of South Korea, part IX; palaeontology VIII, the Machari fauna. J. Fac. Sci., Tokyo Univ., Sec. II, 14(1), 1-152.

Lake, P. 1906: A monograph of the British Cambrian trilobites, part 1. Monogr. Palaeontogr. Soc., London, 1-28.

Lake, P. 1946: Monograph of the British Cambrian trilobites, part 14. Monogr. Palaeontogr. Soc., London, 333-350.

Laurie, J. R. 1988: Revision of some Australian Ptychagnostinae (Agnostida, Cambrian). Alcheringa 12, 169-205.

Laurie, J. R. 1989: Revision of species of Goniagnostus Howell and Lejopyge Corda from Australia (Agnostida, Cambrian). Alcheringa 13, 175-191.

Laurie, J. R. 1990: On the Middle Cambrian agnostoid species Agnostus fallax Linnarsson 1869. Alcheringa 14, 317-324.

Lermontova, E. V. 1940: [Arthropoda.] In Vologdin, A. (ed.), [Atlas of the leading forms of the fossil faunas of the USSR] $\mathbf{1}$, 112-157. Moscow-Leningrad: Gos. Izdat. Geol. Lit. (in Russian).

Lindström, G. 1901: Researches on the visual organs of the trilobites. K. Svenska Vetensk.-Akad. Handl. 34, 1-87.

Linnarsson, J. G. O. 1869: Om Vestergötlands Cambriska och Siluriska aflagringar. K. Svenska Vetensk.-Akad. Handl. 8(2), $1-89$.

Linnarsson, J. G. O. 1879: Om faunan i kalken med Conocoryphe exsulans ('Coronatuskalken'). Sver. geol. Unders. C 35, 1-31.

Linnarsson, J. G. O. 1883 [dated 1882]: De undre Paradoxideslagren vid Andrarum. Sver. geol. Unders. C 54, 1-48.

Lu Yen-hao 1957: [Trilobita.] In [Index fossils of China, Invertebrata] 3, 249-294. Peking: Geological Press (in Chinese).

Lu Yen-hao, Chang Wen-tang, Chu Chao-ling, Chien Yi-yuan \& Hsiang Lee-wen 1965: [Fossils of each group of China; Chinese trilobites.] Vol. 1, 1-362; vol. 2, 363-766. Peking: Science Publication Company (in Chinese).

Lu Yanhao \& Lin Huanling 1989: [The Cambrian trilobites of western Zhejiang.] Palaeont. Sin. 178(N S B, 25), 1-287 (in Chinese with English summary).

$M^{\circ} \mathrm{Coy}$, F. 1849: On the classification of some British fossil Crustacea, with notices of new forms in the university collection at Cambridge. Ann. Mag. Nat. Hist. (London), ser. 2, 4, 161-179, 392-414.

Matthew, G. F. 1896: Faunas of the Paradoxides beds in eastern North America, no. 1. Trans. New York Acad. Sci. 15, 192247.

Matthew, G. F. 1899: Studies on Cambrian faunas, no. 3; Upper Cambrian fauna of Mount Stehphen, British Columbia. Trans. R. Soc. Canada, ser. 2, 5(4), 39-66.
Morris, S. F. 1988: A review of British trilobites, including a a synoptic revision of Salter's monograph. Monogr. Palaeontogr. Soc., London 140(574), $316 \mathrm{pp}$.

Morris, S. F. \& Fortey, R. A. 1985: Catalogue of the type and figured specimens of Trilobita in the British Museum (Natural History), 183 pp. London: British Museum (Natural History).

Müller, K. J. \& Walossek, D. 1987: Morphology, ontogeny, and life habit of Agnostus pisiformis from the Upper Cambrian of Sweden. Fossils \& Strata 19, 124 pp.

Murphy, M. A. 1977: On time-stratigraphic units. J. Paleont. 51, 213-219.

Nicholas, T. C. 1916 [dated 1915]: Notes on the trilobite fauna of the Middle Cambrian of the St. Tudwal's Peninsula (Carnarvonshire). Q. Jl geol. Soc. Lond. 71, 451-472.

Nikolaisen, F. \& Henningsmoen, G. 1990: Lower and Middle Cambrian trilobites from the Digermul Peninsula, Finnmark, northern Norway. Norsk geol. Unders. Bull. 419, 55-95.

Öpik, A. A. 1961: The geology and palaeontology of the headwaters of the Burke River, Queensland. Bur. Miner. Resour. Aust. Bull. 53, 249 pp.

Öpik, A. A. 1967: The Mindyallan fauna of north-western Queensland. Bur. Miner. Resour. Aust. Bull. 74, vol. 1, 404 pp.; vol. 2, 167 pp., 67 pls.

Öpik, A. A. 1979: Middle Cambrian agnostids: systematics and biostratigraphy. Bur. Miner. Resour. Aust. Bull. 172, vol. 1, 188 pp.; vol. 2, 67 pls.

Palmer, A. R. 1962: Glyptagnostus and associated trilobites in the United States. U.S. geol. Surv. Prof. Pap. 374F, 49 pp.

Palmer, A. R. 1968: Cambrian trilobites of east-central Alaska. U.S. geol. Surv. Prof. Pap. 559B, 115 pp.

Pek, I. \& Vaněk, J. 1971: Revision of the genera Peronopsis Hawle et Corda, 1847 and Diplorrhina Hawle et Corda, 1847 (Trilobita) from the Middle Cambrian of Bohemia. Věstnik Ústřed. Úst. geol. 46, 269-275.

Pokrovskaya, N. V. 1958: [Middle Cambrian agnostids of Yakutia, part I.] Trudy Geol. Inst., Akad. Nauk SSSR 16, 1-96 (in Russian).

Poulsen, C. 1960: Fossils from the late Middle Cambrian Bo laspidella Zone of Mendoza, Argentina. Mat.-fys. Medd. Danske Vid. Selsk. 32, 42 pp.

Poulsen, V. 1966: Cambro-Silurian stratigraphy of Bornholm. Meddr dansk geol. Foren. 16, 117-137.

Poulsen, V. 1969: An Atlantic Middle Cambrian fauna from North Greenland. Lethaia 2, 1-14.

Poulsen, V. \& Anderson, M. M. 1975: The Middle - Upper Cambrian transition in southeastern Newfoundland, Canada. Can. J. Earth Sci. 12, 2065-2079.

Qiu Hong-an et al. 1983: [Trilobita.] In Nanjing Inst. Miner. Resour. [Paleontological atlas of east China; vol. I, early Paleozoic], 28-254. Beijing: Geological Publishing House (in Chinese).

Rasetti, F. 1948: Middle Cambrian trilobites from the conglomerates of Quebec. J. Paleont. 22, 315-339.

Rasetti, F. 1967: Lower and Middle Cambrian trilobite faunas from the Taconic sequence of New York. Smithson. misc. Collns 152(4), $111 \mathrm{pp}$

Rasetti, F. \& Theokritoff, G. 1967: Lower Cambrian agnostid trilobites of North America. J. Paleont. 41, 189-196. 
Repina, L. N., Petrunina, Z. E. \& Khajrullina, T. I. 1975: [Trilobites.] In Repina, L. N. et al., [Stratigraphy and fauna of the lower Paleozoic of the northern submontane belt of Turkestan and the Alai ridges (southern Tian Shan).] Trudy Inst. Geol. Geofiz., Akad. Nauk SSSR, Sibir. Otdel. 278, 100-233 (in Russian).

Resser, C. E. 1939: The Spence Shale and its fauna. Smithson. misc. Collns 97(12), 29 pp.

Resser, C. E. \& Howell, B. F. 1938: Lower Cambrian Olenellus Zone of the Appalachians. Bull. geol. Soc. Am. 49, 195-248.

Robison, R. A. 1964: Late Middle Cambrian faunas from western Utah. J. Paleont. 38, 510-566.

Robison, R. A. 1972a: Hypostoma of agnostid trilobites. Lethaia 5, 239-248.

Robison, R. A. 1972b: Mode of life of agnostid trilobites. Proc. 24 int. geol. Congr. Montreal 7, 33-40.

Robison, R. A. 1976: Middle Cambrian trilobite biostratigraphy of the Great Basin. Geol. Stud. Brigham Young Univ. 23(2), 93-109.

Robison, R. A. 1978: Origin, taxonomy, and homeomorphs of Doryagnostus (Cambrian Trilobita). Paleontol. Contr. Univ. Kansas Pap. 91, 10 pp.

Robison, R. A. 1982: Some Middle Cambrian agnostoid trilobites from western North America. J. Paleont. 56, 132-160.

Robison, R. A. 1984: Cambrian Agnostida of North America and Greenland; part I, Ptychagnostidae. Paleontol. Contr. Univ. Kansas Pap. 109, 59 pp.

Robison, R. A. 1987: Class Trilobita. In Boardman, R. S. et al. (ed.) Fossil invertebrates, 221-241. Palo Alto, California: Blackwell.

Robison, R. A. 1988: Trilobites of the Holm Dal Formation (late Middle Cambrian), central North Greenland. Meddr Grønland Geosci. 20, 23-103.

Robison, R. A. 1991: Middle Cambrian biotic diversity: examples from four Utah lagerstatten. In Simonetta, A. M. \& Conway Morris, S. (ed.) The early evolution of metazoa and the significance of problematic taxa, 77-98. Cambridge: Cambridge Univ. Press.

Robison, R. A. \& Pantoja-Alor, J. 1968: Tremadocian trilobites from the Nochixtlan region, Oaxaca, Mexico. J. Paleont. 42, $767-800$

Rosova, A. V. 1964: [Biostratigraphy and description of trilobites of the Middle and Upper Cambrian of the northwestern Siberian platform.] Inst. Geol. Geofiz., Akad. Nauk SSSR, Sibir. Otdel., 1-148 (in Russian).

Rosova, A. V. 1977: [Upper Cambrian and Lower Ordovician of the Rubnoi, Khartaiki, Kureiki and Letnei river basins.] In Chernysheva, N. E. \& Rosova, A. V. (ed.) [Biostratigraphy and fauna of the Upper Cambrian and its boundary layers.] Trudy Inst. Geol. Geofiz., Adad. Nauk SSSR, Sibir. Otdel. 313, 54-84 (in Russian).

Rowell, A. J., Robison, R. A. \& Strickland, D. K. 1982: Aspects of Cambrian agnostoid phylogeny and chronocorrelation. $J$. Paleont. 56, 161-182.

Rushton, A. W. A. 1978: Fossils from the Middle - Upper Cambrian transition in the Nuneaton district. Palaeontology 21, 245-283.

Rushton, A. W. A. 1979: A review of the Middle Cambrian
Agnostida from the Abbey Shales, England. Alcheringa 3, $43-61$.

Rushton, A. W. A. 1983: Trilobites from the Upper Cambrian Olenus Zone in central England. Spec. Pap. Paleontology 30, 107-139.

Salter, J. W. 1864: A monograph of the British trilobites from the Cambrian, Silurian, and Devonian formations. Monogr. Palaeontogr. Soc., London, 80 pp.

Samson, S., Palmer, A. R., Robison, R. A. \& Secor, D. T. 1990: Biogeographical significance of Cambrian trilobites from the Carolina slate belt. Bull. geol. Soc. Am. 102, 1459-1470.

Savitsky, V. E., Evtushenko, V. M., Egorova, L. I., Kontorovich, A. E. \& Shabanov, Yu. Ya. 1972: [Cambrian of the Siberian platform (Judomian-Olenetsky type section, Kuonamsky Complex deposits).] Trudy Sibir. Nauchno-Issled. Inst. Geol. Geofiz. Miner. Syr. 130, 1-200 (in Russian).

Sdzuy, K. 1961: Teil II: Trilobiten. In Lotze, F. \& Sdzuy, K.: Das Kambrium Spaniens. Abh. Akad. Wiss. Lit. Mainz, Abh. math.-naturwiss. Kl. 7, 499-594.

Shaw, A. B. 1966: Paleontology of northwestern Vermont. XI. Fossils from the Middle Cambrian St. Albans Shale. J. Paleont. 40, 843-858.

Shergold, J. H. 1982: Idamean (Late Cambrian) trilobites, Burke River structural belt, western Queensland. Bur. Miner. Resour. Austr. Bull. 187, 103 pp.

Shergold, J. H. \& Laurie, J. R. 1991: Ptychagnostus Jaekel, 1909 and Glyptagnostus Whitehouse, 1936 (Trilobita): proposed conservation of accepted usage. Bull. Zool. Nomenclature 48(3), 200-202.

Shergold, J. H., Laurie, J. R. \& Sun Xiaowen 1990: Classification and review of the trilobite order Agnostida Salter, 1864: an Australian perspective. Bur. Miner. Resour. Aust. Rep. 296, $93 \mathrm{pp}$.

Šnajdr, M. 1957: O novych trilobitech z ceskeho kambria. Věstnik Ústřed. Úst. geol. 32, 235-244.

Šnajdr, M. 1958: Trilobiti českého středního kambria. Rospravy Ústřed. Úst. geol. 24, 1-280.

Song Yanping 1989: Upper Middle Cambrian trilobite biostratigraphy of western Hunan, China. Unpublished M.S. thesis, Univ. Kansas, Lawrence, 75 pp.

Sun Xiaowen 1989: Cambrian agnostids from the north China platform. Palaeontol. Cathayana 4, 53-129.

Swofford, D. L. 1990: PAUP: phylogenetic analysis using parsimony, version $3.0,35 \mathrm{pp}$. Computer program distributed by the Illinois Natural History Survey, Champaign, Illinois.

Tullberg, S. A. 1880: Om Agnostus-arterna i de Kambriska aflagringarne vid Andrarum. Sver. geol. Unders. C 42, 37 pp.

Wahlenberg, G. 1818: Petrificata telluris Svecanae. Nova Acta R. Soc. Sci. Upsala 8, 116 pp.

Walossek, D. \& Müller, K. J. 1990: Upper Cambrian stemlineage crustaceans and their bearing upon the monophyletic origin of Crustacea and the position of Agnostus. Lethaia 23, 409-427.

Wang Shuei et al. 1963: [Handbook of fossils, northwestern China], 179 pp. Peking: Science Press, Academia Sinica (in Chinese).

Westergård, A. H. 1936: Paradoxides oelandicus beds of Öland. Sver. geol. Unders. C 394, 66 pp. 
Westergård, A. H. 1946: Agnostidea of the Middle Cambrian of Sweden. Sver. geol. Unders. C 477, 141 pp.

Westergård, A. H. 1947: Supplementary notes on the Upper Cambrian trilobites of Sweden. Sver. geol. Unders. C 489, 35 pp.

White, C. A. 1874: Preliminary report upon invertebrate fossils, with descriptions of new species. U.S. geol. Exploration West 100th Meridian [Wheeler Survey], pamphlet, $27 \mathrm{pp}$.

Whitehouse, F. W. 1936: The Cambrian faunas of north-eastern Australia, parts 1 and 2. Mem. Queensland Mus. 11, 59-112.

Whitehouse, F. W. 1939: The Cambrian faunas of north-eastern Australia, Part 3. Mem. Queensland Mus. N S 1, 179-282.

Williamson, D. I. 1982: Larval morphology and diversity. In Abele, L. G. (ed.) The biology of Crustacea. Vol. 2, Embryology, morphology, and genetics, 43-110. New York: Academic Press.

Xiang Liwen \& Zhang Tai-rong 1985: [Systematic descriptions of trilobites.] In [Stratigraphy and trilobite faunas of the Cambrian in the western part of the northern Tian Shan, Xinjiang.] Minist. Geol. Miner. Resour., Geol. Mem. 2(4), 64-243 (in Chinese with English summary).

Xiang Liwen et al. 1981. [The Cambrian System of China.] Chinese Acad. Geol., Stratig. China 4, 210 pp. (in Chinese).
Yang Jia-lu 1978: [Middle and Upper Cambrian trilobites of western Hunan and eastern Guizhou.] Chinese Acad. Geol. Sci., Prof. Pap. Stratigr. Paleont. 4, 1-82 (in Chinese).

Yang Jia-lu 1982: [Notes on the Middle Cambrian trilobite faunas from Duibian of Jiangshan, Zhejiang.] Geol. Rev. 28(4), 299-307 (in Chinese with English abstract).

Young, G. A. \& Ludvigsen, R. 1989: Mid-Cambrian trilobites from the lowest part of the Cow Head Group, western Newfoundland. Bull. geol. Surv. Can. 392, 49 pp.

Zhang Yu-song (ed.) 1983: [Paleontological atlas of east China; part 1, early Paleozoic.] Nanjing Inst. Geol. Miner. Resour., 657 pp. Beijing: Geol. Publishing House (in Chinese).

Zhang Wentang \& Jell, P. A. 1987: Cambrian trilobites of north China; Chinese Cambrian trilobites housed in the Smithsonian Institution, 459 pp. Beijing: Science Press.

Zhou Tien-mei, Liu Yi-jeng, Mong Sien-sung \& Sun Zheng-hua 1977: [Trilobita.] In Wang Xiao-feng \& Jin Yu-qin (ed.) [Palaeontological handbook of central and southern China; part I, early Palaeozoic Era], 104-266. Beijing: Sciences Press (in Chinese). 